\title{
Nitric oxide and nitrous oxide turnover in natural and engineered microbial communities: biological pathways, chemical reactions, and novel technologies
}

\author{
Frank Schreiber ${ }^{1,2 *}$, Pascal Wunderlin ${ }^{3}$, Kai M. Udert ${ }^{3}$ and George F. Wells ${ }^{3,4}$ \\ ${ }^{1}$ Department of Environmental Microbiology, Eawag - Swiss Federal Institute of Aquatic Science and Technology, Dübendorf, Switzerland \\ ${ }^{2}$ Department of Environmental Systems Sciences, Eidgenössische Technische Hochschule, Zurich, Switzerland \\ ${ }^{3}$ Department of Process Engineering, Eawag - Swiss Federal Institute of Aquatic Science and Technology, Dübendorf, Switzerland \\ ${ }^{4}$ Department of Civil, Environmental and Geomatic Engineering, Eidgenössische Technische Hochschule, Zurich, Switzerland
}

\section{Edited by:}

Boran Kartal, Radboud University, Netherlands

\section{Reviewed by:}

Robbert Kleerebezem, Delft

University of Technology,

Netherlands

Kartik Chandran, Columbia

University, USA

*Correspondence:

Frank Schreiber, Department of Environmental Microbiology,

Eawag-Swiss Federal Institute of Aquatic Science and Technology,

Überlandstrasse 133, P.O. Box 611, 8600 Dübendorf, Switzerland.

e-mail: frank.schreiber@eawag.ch
Nitrous oxide $\left(\mathrm{N}_{2} \mathrm{O}\right)$ is an environmentally important atmospheric trace gas because it is an effective greenhouse gas and it leads to ozone depletion through photo-chemical nitric oxide (NO) production in the stratosphere. Mitigating its steady increase in atmospheric concentration requires an understanding of the mechanisms that lead to its formation in natural and engineered microbial communities. $\mathrm{N}_{2} \mathrm{O}$ is formed biologically from the oxidation of hydroxylamine $\left(\mathrm{NH}_{2} \mathrm{OH}\right)$ or the reduction of nitrite $\left(\mathrm{NO}_{2}^{-}\right)$to $\mathrm{NO}$ and further to $\mathrm{N}_{2} \mathrm{O}$. Our review of the biological pathways for $\mathrm{N}_{2} \mathrm{O}$ production shows that apparently all organisms and pathways known to be involved in the catabolic branch of microbial $\mathrm{N}$-cycle have the potential to catalyze the reduction of $\mathrm{NO}_{2}^{-}$to $\mathrm{NO}$ and the further reduction of $\mathrm{NO}$ to $\mathrm{N}_{2} \mathrm{O}$, while $\mathrm{N}_{2} \mathrm{O}$ formation from $\mathrm{NH}_{2} \mathrm{OH}$ is only performed by ammonia oxidizing bacteria (AOB). In addition to biological pathways, we review important chemical reactions that can lead to $\mathrm{NO}$ and $\mathrm{N}_{2} \mathrm{O}$ formation due to the reactivity of $\mathrm{NO}_{2}^{-}, \mathrm{NH}_{2} \mathrm{OH}$, and nitroxyl ( $\mathrm{HNO}$ ). Moreover, biological $\mathrm{N}_{2} \mathrm{O}$ formation is highly dynamic in response to $\mathrm{N}$-imbalance imposed on a system. Thus, understanding $\mathrm{NO}$ formation and capturing the dynamics of $\mathrm{NO}$ and $\mathrm{N}_{2} \mathrm{O}$ build-up are key to understand mechanisms of $\mathrm{N}_{2} \mathrm{O}$ release. Here, we discuss novel technologies that allow experiments on $\mathrm{NO}$ and $\mathrm{N}_{2} \mathrm{O}$ formation at high temporal resolution, namely $\mathrm{NO}$ and $\mathrm{N}_{2} \mathrm{O}$ microelectrodes and the dynamic analysis of the isotopic signature of $\mathrm{N}_{2} \mathrm{O}$ with quantum cascade laser absorption spectroscopy (QCLAS). In addition, we introduce other techniques that use the isotopic composition of $\mathrm{N}_{2} \mathrm{O}$ to distinguish production pathways and findings that were made with emerging molecular techniques in complex environments. Finally, we discuss how a combination of the presented tools might help to address important open questions on pathways and controls of nitrogen flow through complex microbial communities that eventually lead to $\mathrm{N}_{2} \mathrm{O}$ build-up.

Keywords: isotopic signature, microsensors, molecular tools, dinitrogen oxide, nitrogen monoxide, pathway identification, quantum cascade laser absorption spectroscopy (OCLAS), site preference

\section{INTRODUCTION}

Nitric oxide $(\mathrm{NO})$ and nitrous oxide $\left(\mathrm{N}_{2} \mathrm{O}\right)$ are atmospheric trace gases that influence atmospheric chemistry and the greenhouse effect. Biological and chemical processes produce $\mathrm{N}_{2} \mathrm{O}$ on the earth surface (Crutzen, 1979). Entering the stratosphere, $\mathrm{N}_{2} \mathrm{O}$ is converted to NO by photo-oxidation. NO together with nitrogen dioxide $\left(\mathrm{NO}_{2}\right)$ participate in a set of reactions that transfer ozone $\left(\mathrm{O}_{3}\right)$ to molecular oxygen $\left(\mathrm{O}_{2}\right)$, thereby leading to $\mathrm{O}_{3}$ layer depletion. In fact, $\mathrm{N}_{2} \mathrm{O}$ is and will remain the dominant $\mathrm{O}_{3}$-depleting substance in the twenty-first century (Ravishankara et al., 2009), since the use of chlorofluorocarbons has been restricted by the Montreal Protocol. In addition, $\mathrm{N}_{2} \mathrm{O}$ is a potent greenhouse gas. The infrared radiative forcing of one $\mathrm{N}_{2} \mathrm{O}$ molecule is 206 times that of one carbon dioxide $\left(\mathrm{CO}_{2}\right)$ molecule (Stein and Yung, 2003). Together with the long atmospheric lifetime of $\mathrm{N}_{2} \mathrm{O}$ $(\sim 120$ years $)$ this results in a $\sim 300$ times higher global warming potential of $\mathrm{N}_{2} \mathrm{O}$ than that of $\mathrm{CO}_{2}$ on a per molecule basis. Overall, $\mathrm{N}_{2} \mathrm{O}$ contributes $6-8 \%$ to the anthropogenic greenhouse effect, despite its relatively low atmospheric concentration ( 322 ppbv) (Montzka et al., 2011).

Over the last 100 years atmospheric $\mathrm{N}_{2} \mathrm{O}$ concentrations have been steadily increasing due to the massive introduction of fixed nitrogen into the environment by humans (IPCC, 2001). Counteracting the further increase of $\mathrm{N}_{2} \mathrm{O}$ in the atmosphere will rely on (1) decreasing the introduction of fixed nitrogen into the environment by humans, (2) exactly quantifying the important environmental sources of $\mathrm{N}_{2} \mathrm{O}$, and (3) implementing effective strategies to mitigate its formation in nitrogen-transforming, man-made ecosystems such as agriculture and wastewater treatment. Thus, there is an urgent need to understand the mechanisms that underpin the formation of $\mathrm{N}_{2} \mathrm{O}$ in natural and engineered microbial communities. 
In this review, we will outline the current state-of-the-art on biological and chemical processes that can produce and consume $\mathrm{N}_{2} \mathrm{O}$ and $\mathrm{NO}$ - an important precursor of $\mathrm{N}_{2} \mathrm{O}$ in many biological pathways. We will discuss pathways that produce $\mathrm{NO}$ and $\mathrm{N}_{2} \mathrm{O}$ in natural and engineered microbial communities and experimental approaches that can be used to distinguish between different pathways in these systems. Importantly, $\mathrm{NO}$ and $\mathrm{N}_{2} \mathrm{O}$ formation can be highly dynamic and occur at small spatial scales. Thus, we will further introduce two novel technologies that provide such data and how they can lead to mechanistic insight: (1) NO and $\mathrm{N}_{2} \mathrm{O}$ microelectrodes and (2) the analysis of the site preference (SP) in $\mathrm{N}_{2} \mathrm{O}$ measured with quantum cascade laser absorption spectroscopy (QCLAS). In addition, we discuss the challenges of incorporating molecular biological techniques in this scheme.

\section{BIOLOGICAL PATHWAYS FOR NO AND $\mathrm{N}_{2} \mathrm{O}$ PRODUCTION}

The study of laboratory cultures for pathways and controls of $\mathrm{NO}$ and $\mathrm{N}_{2} \mathrm{O}$ production in different organisms has generated considerable knowledge, which was partly reviewed recently (Stein, 2011; Chandran et al., 2011). Figure 1 shows that the sequential reduction of nitrite $\left(\mathrm{NO}_{2}^{-}\right)$to $\mathrm{NO}$ and further to $\mathrm{N}_{2} \mathrm{O}$ can be performed by all organisms involved in the catabolic branch of the $\mathrm{N}$-cycle. While all $\mathrm{N}$-cycle organisms can perform these reactions it is currently believed that denitrifiers and ammonia oxidizing bacteria $(\mathrm{AOB})$ and ammonia oxidizing archaea $(\mathrm{AOA})$ are the most important environmental sources of $\mathrm{N}_{2} \mathrm{O}$. However, in the following section we additionally review the evidence for $\mathrm{NO}$ and $\mathrm{N}_{2} \mathrm{O}$ production by nitrite oxidizing bacteria (NOB), anaerobic methane (N-AOM) and $\mathrm{AOB}$ (anammox), and bacteria that

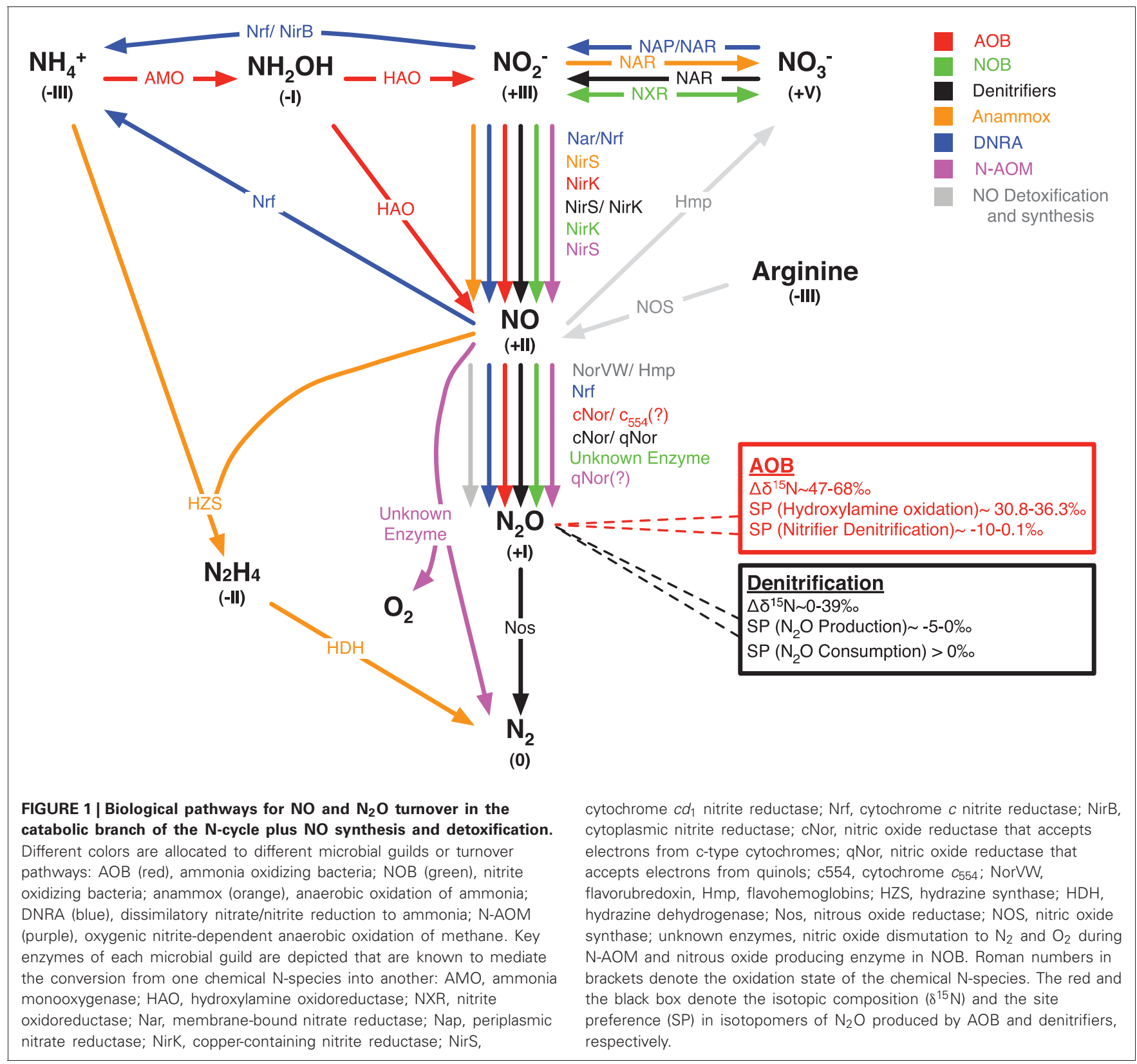


perform dissimilatory nitrate reduction to ammonia (DNRA). Even though it is clear that these bacteria can produce NO and $\mathrm{N}_{2} \mathrm{O}$ there is only few information on the controls, conditions and magnitude for $\mathrm{NO}$ and $\mathrm{N}_{2} \mathrm{O}$ production by these bacteria in the laboratory and in the environment. This should be an important aspect of future research as e.g., DNRA and anammox are the major $\mathrm{N}$-conversion pathways in some important environments.

\section{DENITRIFICATION}

The key enzyme for NO formation during denitrification is nitrite reductase (Nir). Purification and characterization of Nir from several bacteria revealed two entirely different periplasmic enzymes: a heme-containing cytochrome $c d_{1}$ Nir (NirS) and a copper-containing Nir (NirK) as reviewed by Cutruzzolà (1999). Reduction of $\mathrm{NO}$ to $\mathrm{N}_{2} \mathrm{O}$ is mediated by respiratory nitric oxide reductases (Nor). Respiratory Nor proteins are integral membrane proteins that fall into two groups: one is a cytochrome $b c$ complex that can use c-type cytochromes as electron donors (cNor), whereas the other one lacks a cytochrome $c$ component and accepts electrons from quinols (qNor; sometimes termed NorZ) (Hendriks et al., 2000; Zumft, 2005). Few bacteria use qNor for classical denitrification. Rather, qNor is mainly encoded by pathogenic bacteria that use it for NO detoxification and the survival of anoxic periods when expressed in concert with Nir, as shown for Neisseria spp. (Anjum et al., 2002; Rock et al., 2007). The final step in denitrification is mediated by nitrous oxide reductase (Nos), a multi-copper enzyme that reduces $\mathrm{N}_{2} \mathrm{O}$ to dinitrogen $\left(\mathrm{N}_{2}\right)$ (Zumft and Kroneck, 2007).

$\mathrm{N}_{2} \mathrm{O}$ reduction by Nos is the only known $\mathrm{N}_{2} \mathrm{O}$ consuming process that can counteract release of $\mathrm{N}_{2} \mathrm{O}$ from ecosystems (Richardson et al., 2009). Accumulation of $\mathrm{N}_{2} \mathrm{O}$ is often observed in pure cultures (Baumann et al., 1996; Otte et al., 1996; Kester et al., 1997; Bergaust et al., 2010) and mixed microbial communities (Firestone and Tiedje, 1979; Firestone et al., 1980; Morley et al., 2008; Kampschreur et al., 2008b; Schreiber et al., 2009; Elberling et al., 2010; Pellicer-Nàcher et al., 2010; Liengaard et al., 2011) during transitions from anoxic to oxic conditions or vice versa (Table 1). Even in pure cultures the physiological basis for this is not well understood because it probably has multiple, strain-specific reasons. It has been hypothesized that Nos is-unlike Nir and Nor-inhibited by $\mathrm{O}_{2}$ (Morley et al., 2008), but in pure cultures evidence for $\mathrm{O}_{2}$-insensitive (Berks et al., 1993 ) and $\mathrm{O}_{2}$-sensitive (Otte et al., 1996) Nos have been reported. Likewise, it has been argued that expression of Nos is slower than that of the preceding denitrification enzymes (Firestone et al., 1980; Stief et al., 2009), but in Paracoccus denitrificans Nos synthesis is faster (Baumann et al., 1996; Bergaust et al., 2010) and in Pseudomonas stutzeri Nos is even constitutively expressed at low levels (Körner and Zumft, 1989). More studies on Nos expression in relation to $\mathrm{N}_{2} \mathrm{O}$ production pathways and on Nos inhibition by $\mathrm{O}_{2}$ are needed with environmentally relevant isolates and mixed microbial communities. Additional factors that lead $\mathrm{N}_{2} \mathrm{O}$ accumulation are the slower turnover of Nos at low $\mathrm{pH}$ as compared to nitrate reductase (Nar), Nir, and Nor (Richardson et al., 2009; Bergaust et al., 2010), low pH during Nos assembly (Bergaust et al., 2010), inhibition of Nos by nitrous acid formed from $\mathrm{NO}_{2}^{-}$ at low $\mathrm{pH}$ (Zhou et al., 2008), inhibition of Nos by exogenously produced NO (Frunzke and Zumft, 1986; Schreiber et al., unpublished results) or hydrogen sulfide $\left(\mathrm{H}_{2} \mathrm{~S}\right)$ (Sørensen et al., 1980) and copper limitation (Granger and Ward, 2012).

\section{AMMONIA OXIDIZING BACTERIA (AOB)}

High levels of $\mathrm{NO}$ and $\mathrm{N}_{2} \mathrm{O}$ can be produced by pure cultures of aerobic AOB (Lipschultz et al., 1981; Kester et al., 1997; Shaw et al., 2006), but the mechanism is not completely understood. Generally, two different pathways are inferred. First, the activity of nitrifier-encoded NirK and cNor reduces $\mathrm{NO}_{2}^{-}$to $\mathrm{NO}$ and $\mathrm{N}_{2} \mathrm{O}$ in a pathway termed nitrifier denitrification (Poth and Focht, 1985; Wrage et al., 2001; Schmidt et al., 2004b). A few reports exist on $\mathrm{N}_{2}$ formation by $\mathrm{AOB}$ during nitrifier denitrification, but a nos $Z$ gene or functional Nos in AOB was not demonstrated (Poth, 1986; Schmidt et al., 2004b; Schmidt, 2009). The term nitrifier denitrification is somewhat misleading as it has until now not been shown that it is a true dissimilatory process for energy conservation and growth, but rather may be a detoxification mechanism to counteract the accumulation of $\mathrm{NO}_{2}^{-}$to toxic concentrations (Beaumont et al., 2002, 2004a,b).

In the second pathway, $\mathrm{N}_{2} \mathrm{O}$ is formed by hydroxylamine $\left(\mathrm{NH}_{2} \mathrm{OH}\right)$ oxidation. The current model is that hydroxylamine oxidoreductase (HAO) oxidizes $\mathrm{NH}_{2} \mathrm{OH}$ to $\mathrm{NO}$ (Hooper, 1968; Hooper and Terry, 1979). NO is then reduced to $\mathrm{N}_{2} \mathrm{O}$ by a yet unidentified Nor; a potential candidate is cytochrome $c_{554}$ (Upadhyay et al., 2006). However, the catalytic cycle of HAO, including its intermediates and its catalytic potential are a subject of ongoing debate (Hendrich et al., 2002; Cabail and Pacheco, 2003; Cabail et al., 2005; Fernández et al., 2008; Kostera et al., 2008) and as of yet direct formation of $\mathrm{N}_{2} \mathrm{O}$ from $\mathrm{HAO}$ or other reactions can not be excluded. Indeed, the difference in the SP of $\mathrm{N}_{2} \mathrm{O}$ produced by $\mathrm{NH}_{2} \mathrm{OH}$ oxidation and nitrifier denitrification indicates that $\mathrm{N}_{2} \mathrm{O}$ might be produced by $\mathrm{HAO}$ by a mechanism that (1) either does not involve NO reduction by canonical Nor used for nitrifier denitrification or (2) does proceed via a completely different mechanism without free $\mathrm{NO}$ as intermediate (discussed in section "site preference" and "HNO as intermediate of enzymatic hydroxylamine oxidation"). Both nitrifier denitrification and $\mathrm{NH}_{2} \mathrm{OH}$ oxidation require $\mathrm{O}_{2}$ to activate ammonia $\left(\mathrm{NH}_{3}\right)$ with ammonia monooxygenase (AMO) to $\mathrm{NH}_{2} \mathrm{OH}$, which serves as a substrate for $\mathrm{HAO}$ or as electron donor to nitrifier denitrification. A pathway in which $\mathrm{AOB}$ perform denitrification with organic substrates instead of $\mathrm{NH}_{3}$ as electron donor (Schmidt, 2009) should be considered heterotrophic denitrification performed by AOB. AOA have also been demonstrated to produce $\mathrm{N}_{2} \mathrm{O}$ probably by pathways akin to AOB (Santoro et al., 2011).

The relative importance of $\mathrm{NH}_{2} \mathrm{OH}$ oxidation and nitrifier denitrification for $\mathrm{NO}$ and $\mathrm{N}_{2} \mathrm{O}$ production is still debated. Based on pure culture investigations Yu et al. (2010) hypothesized that a high $\mathrm{NH}_{3}$ oxidation activity favors $\mathrm{N}_{2} \mathrm{O}$ production via $\mathrm{NH}_{2} \mathrm{OH}$ oxidation. Similarly, Wunderlin et al. (2012) found that $\mathrm{NH}_{2} \mathrm{OH}$ oxidation is favored by high $\mathrm{NH}_{3}$ and low $\mathrm{NO}_{2}^{-}$concentrations, and a high nitrification rate in a mixed culture for treating municipal wastewater. Moreover, stable nitrogen isotopes work with AOB pure cultures showed that $\mathrm{NH}_{2} \mathrm{OH}$ oxidation contributes 


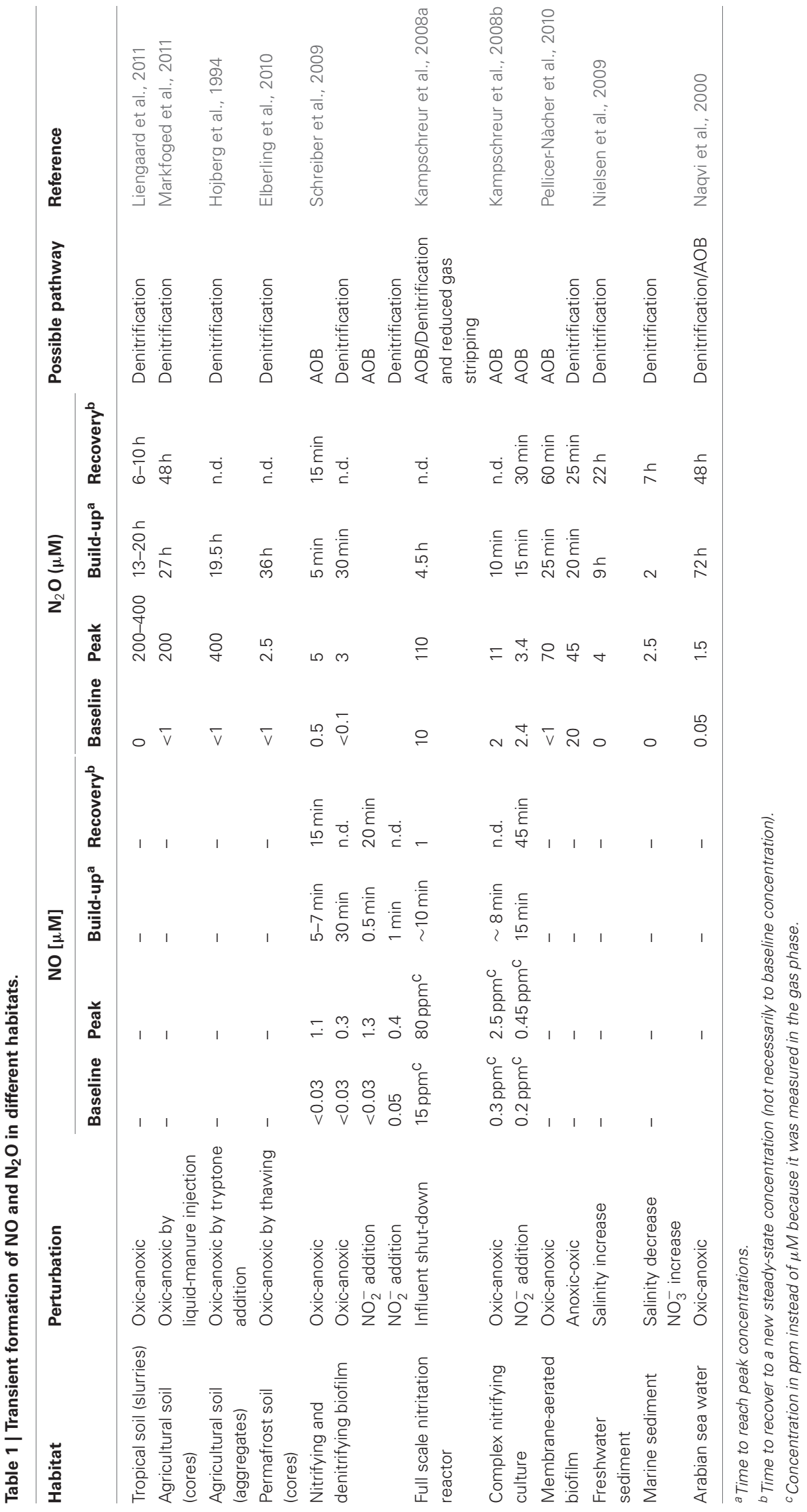


to $\mathrm{N}_{2} \mathrm{O}$ production mainly at high $\mathrm{O}_{2}$ whereas nitrifier denitrification is more active at low $\mathrm{O}_{2}$ concentrations (Sutka et al., 2006).

\section{NITRITE OXIDIZING BACTERIA (NOB)}

NOB form $\mathrm{NO}$ and $\mathrm{N}_{2} \mathrm{O}$ during denitrification of nitrate $\left(\mathrm{NO}_{3}^{-}\right)$ or $\mathrm{NO}_{2}^{-}$with pyruvate or glycerol as electron donor under anoxic conditions (Freitag et al., 1987; Ahlers et al., 1990), but a known NO reductase could not be identified in the genomes of different Nitrobacter species and "Candidatus Nitrospira defluvii" (Starkenburg et al., 2006, 2008b; Lücker et al., 2010). Under anoxic conditions nitrite oxidoreductase (NXR) mediates $\mathrm{NO}_{3}^{-}$ reduction to $\mathrm{NO}_{2}^{-}$, while it mediates the reverse reaction under oxic conditions (Freitag et al., 1987). NOB actively express NirK, which co-purifies with $\mathrm{NXR}$, in the presence of $\mathrm{NO}_{2}^{-}$and if $\mathrm{O}_{2}$ concentrations are low (Ahlers et al., 1990; Starkenburg et al., 2008a). NO generated by NOB-NirK is thought to direct cellular electron flux either toward $\mathrm{O}_{2}$ respiration at high $\mathrm{O}_{2}$ concentrations or toward NADH synthesis by reversibly inhibiting cytochrome oxidase at low $\mathrm{O}_{2}$ concentrations. An interesting question to explore in natural communities would be whether NO produced by $\mathrm{AOB}$ or denitrifying bacteria can influence the activity of NOB.

\section{DISSIMILATORY NITRATE REDUCTION TO AMMONIA (DNRA)}

$\mathrm{NO}$ and $\mathrm{N}_{2} \mathrm{O}$ turnover by bacteria that perform DNRA has been mainly investigated in Escherichia coli and Salmonella typhimurium. In E. coli, NO formation is mediated by cytochrome $c$ nitrite reductase (Nrf) under anoxic conditions in the presence of $\mathrm{NO}_{3}^{-}$and $\mathrm{NO}_{2}^{-}$(Corker and Poole, 2003). NO detoxifying enzymes, such as flavorubredoxin, may further reduce $\mathrm{NO}$ to $\mathrm{N}_{2} \mathrm{O}$. On the other hand, E. coli Nrf reduces $\mathrm{NO}$ to $\mathrm{N}_{2} \mathrm{O}$ or $\mathrm{NH}_{3}$ if electrons are donated to the enzyme at high or low potential, respectively (Costa et al., 1990), contributing to detoxification of exogenously generated NO (van Wonderen et al., 2008). Aerobic and anaerobic $\mathrm{NO}$ formation from $\mathrm{NO}_{2}^{-}$in S. typhimurium is mediated by membrane-bound nitrate reductase (Nar). Under aerobic conditions, activity of NO detoxifying Hmp (see below) oxidizes $\mathrm{NO}$ to $\mathrm{NO}_{3}^{-}$resulting in non-detectable $\mathrm{NO}$ concentrations in culture suspensions (Gilberthorpe and Poole, 2008).

\section{ANAEROBIC METHANE AND AMMONIA OXIDIZING BACTERIA}

Bacteria that mediate the oxygenic nitrite-dependent oxidation of methane (N-AOM) and anaerobic ammonia oxidation (anammox) have been shown to use $\mathrm{NO}$ as an intracellular intermediate produced by $\mathrm{NO}_{2}^{-}$reduction via NirS while they consume exogenous $\mathrm{NO}$ without concurrent $\mathrm{N}_{2} \mathrm{O}$ formation (Ettwig et al., 2010; Kartal et al., 2010, 2011). Rather, N-AOM dismutates NO to form $\mathrm{N}_{2}$ and $\mathrm{O}_{2}$, while anammox couples the reduction of $\mathrm{NO}$ to a condensation with $\mathrm{NH}_{3}$ to produce hydrazine $\left(\mathrm{N}_{2} \mathrm{H}_{4}\right)$. Both have the genetic potential to reduce $\mathrm{NO}$ to $\mathrm{N}_{2} \mathrm{O}$; anammox bacteria encode for flavorubredoxin (Strous et al., 2006) and N-AOM encodes for qNor (Ettwig et al., 2010). However, physiological data for both indicates that they withstand rather high NO levels $(\mathrm{N}$ AOM $20 \mu \mathrm{mol} \mathrm{L} \mathrm{L}^{-1}$, anammox $7 \mu \mathrm{mol} \mathrm{L}^{-1}$ ) without activating anaerobic NO detoxification mechanisms.

\section{$\mathrm{NO}_{2}^{-} \longrightarrow \mathrm{NO} \longrightarrow \mathrm{N}_{2} \mathrm{O}$ : CENTRAL STEPS IN THE N-CYCLE}

Generally, the reduction of $\mathrm{NO}_{2}^{-}$to $\mathrm{NO}$ is a central step in the catabolic branch of the $\mathrm{N}$-cycle, because it can be carried out by all involved organisms (Figure 1). The reduction of $\mathrm{NO}_{2}^{-}$to $\mathrm{NO}$ is central for energy conservation in denitrification, anammox and $\mathrm{N}$-AOM. In contrast, during $\mathrm{NO}_{2}^{-}$oxidation and nitrifier denitrification the reduction of $\mathrm{NO}_{2}^{-}$to $\mathrm{NO}$ is involved in regulating metabolic homeostasis or the removal of toxic $\mathrm{NO}_{2}^{-}$(Beaumont et al., 2002, 2004a; Starkenburg et al., 2008a).

The reduction of $\mathrm{NO}$ to $\mathrm{N}_{2} \mathrm{O}$ is, besides a potential direct formation of $\mathrm{N}_{2} \mathrm{O}$ from $\mathrm{NH}_{2} \mathrm{OH}$ in $\mathrm{AOB}$, the only known biochemical reaction that produces $\mathrm{N}_{2} \mathrm{O}$. NO reduction to $\mathrm{N}_{2} \mathrm{O}$ is central for energy conservation only in denitrification (Zumft, 1997). The function of $\mathrm{cNor}$ in AOB is unclear. cNor is expressed and metabolically active during aerobic growth (Beaumont et al., 2004b). Knock-out mutants of cNor have lower growth rate and yield in chemostats (Schmidt et al., 2004b), but not in batch culture (Beaumont et al., 2004b). In chemostats, cNor regulates the free NO concentration to an optimal, non-toxic level and contributes to recovery of AOB from anaerobic conditions (Schmidt et al., 2004b). On the other hand, stripping NO from AOB cultures leads to the inhibition of growth, arguing for NO being an obligate intermediate of AOB (Zart et al., 2000).

\section{NO DETOXIFICATION AND NO SYNTHESIS}

Most bacteria encode for enzymes involved in NO detoxification. This is true for bacteria inside and outside the catabolic N-cycle. Flavohemoglobins ( $\mathrm{Hmp}$ ) mediate the $\mathrm{O}_{2}$-dependent detoxification of $\mathrm{NO}$ to $\mathrm{NO}_{3}^{-}$with $\mathrm{NO}$ dioxygenase activity (Gardner et al., 1998). In contrast, the anaerobic detoxification of NO is mediated by Flavodiiron NO reductase (flavorubredoxin [NorVW]) and $\mathrm{Hmp}$ by reducing $\mathrm{NO}$ to $\mathrm{N}_{2} \mathrm{O}$ (Kim et al., 1999; Gardner et al., 2002; Gomes et al., 2002).

An alternative, less explored route to $\mathrm{N}_{2} \mathrm{O}$ formation is via the synthesis of NO from arginine by NO synthases (NOS) and subsequent reduction of $\mathrm{NO}$ to $\mathrm{N}_{2} \mathrm{O}$ by cNor, qNor, Hmp or NorVW. Because NOS was discovered in the medical field it shares a similar abbreviation with $\mathrm{N}_{2} \mathrm{O}$ reductases (Nos). Until now, NOS has only been detected in a few bacterial -mostly gram-positive species (Sudhamsu and Crane, 2009) and synthesized NO seems to remain intracellular (Shatalin et al., 2008; Schreiber et al., 2011). However, NOS activity has also been reported in blooming, pelagic diatoms (Vardi et al., 2006). More research is needed to elucidate if NOS-derived $\mathrm{NO}$ is a significant source for $\mathrm{N}_{2} \mathrm{O}$ emitted from phytoplankton blooms in oceans and freshwater.

\section{CHEMICAL REACTIONS IN NO AND $\mathrm{N}_{2} \mathrm{O}$ TURNOVER}

Chemical production of $\mathrm{NO}$ and $\mathrm{N}_{2} \mathrm{O}$ from inorganic nitrogen compounds at ambient temperatures are well known phenomena in soil science (van Cleemput and Samater, 1996) and atmospheric chemistry (Lammel and Cape, 1996). In soil science, the chemical processes leading to $\mathrm{NO}$ and $\mathrm{N}_{2} \mathrm{O}$ are often summarized as chemo-denitrification (Chalk and Smith, 1983). $\mathrm{NH}_{2} \mathrm{OH}$ and $\mathrm{NO}_{2}^{-}$(or its acid $\mathrm{HNO}_{2}$ ) are the main precursors for chemical production of $\mathrm{NO}$ and $\mathrm{N}_{2} \mathrm{O}$ in wastewater or natural waters. In the following, we discuss chemical reactions involving $\mathrm{HNO}$, $\mathrm{NH}_{2} \mathrm{OH}$, and $\mathrm{NO}_{2}^{-}$that can be responsible for the release of 
$\mathrm{NO}$ and $\mathrm{N}_{2} \mathrm{O}$. We will also discuss the possible significance of chemical $\mathrm{N}_{2} \mathrm{O}$ production during biological $\mathrm{NH}_{2} \mathrm{OH}$ oxidation.

\section{SIGNIFICANCE OF HNO}

In many studies on chemical $\mathrm{N}_{2} \mathrm{O}$ production, $\mathrm{HNO}$ is postulated as the direct precursor of $\mathrm{N}_{2} \mathrm{O}$ (see below): $\mathrm{HNO}$ dimerizes via hyponitrous acid $\left(\mathrm{H}_{2} \mathrm{~N}_{2} \mathrm{O}_{2}\right)$, to $\mathrm{N}_{2} \mathrm{O}$ and $\mathrm{H}_{2} \mathrm{O}$ (Bonner and Hughes, 1988).

$$
2 \mathrm{HNO} \rightarrow \mathrm{H}_{2} \mathrm{~N}_{2} \mathrm{O}_{2} \rightarrow \mathrm{N}_{2} \mathrm{O}+\mathrm{H}_{2} \mathrm{O}
$$

It can be assumed that formation of HNO in natural and wastewater follows the same mechanisms that are used to synthesize HNO (DuMond and King, 2011) in the laboratory: (1) disproportionation of $\mathrm{NH}_{2} \mathrm{OH}$ derivatives containing good leaving groups attached to the nitrogen atom, and (2) decomposition of nitroso compounds $(\mathrm{X}-\mathrm{N}=\mathrm{O}$, where $\mathrm{X}$ represents a good leaving group). Chemical HNO production are likely to occur during wastewater treatment, since nitrification can produce considerable amounts of both, $\mathrm{HNO}_{2}$, which is a precursor for nitrosation agents (e.g., dinitrogen trioxide $\mathrm{N}_{2} \mathrm{O}_{3}$, Bonner and Stedman, 1996), and $\mathrm{NH}_{2} \mathrm{OH}$.

Recently, medical researchers have started to reevaluate the relevance of HNO for physiologically and biologically systems (Fehling and Friedrichs, 2011). The increased interest in HNO is due to the fact that HNO lifetime in aqueous solutions is much longer than previously assumed: the HNO dimerization rate constant has been reassessed to be on the order of $8 \times 10^{5} \mathrm{M}^{-1} \cdot \mathrm{s}^{-1}$ instead of the previously reported value of $2 \times 10^{9} \mathrm{M}^{-1} \cdot \mathrm{s}^{-1}$, and the $p K_{a}$ value of $\mathrm{HNO}$ has been redetermined to be 11.4 instead of the old value of 4.2 (Shafirovich and Lymar, 2002). It is likely that the importance of $\mathrm{HNO}$ has also been underestimated in the research on $\mathrm{N}_{2} \mathrm{O}$ emissions. Analytical determination of HNO is very challenging (Miranda, 2005), because HNO is shortlived. However, computer simulations could be a helpful tool to assess the importance of $\mathrm{HNO}$ in $\mathrm{N}_{2} \mathrm{O}$ formation (Law et al., 2012).

\section{$\mathrm{HNO}_{2}$ DISPROPORTIONATION}

A well understood process for NO production is the disproportionation of $\mathrm{HNO}_{2}$ (Udert et al., 2005). Since the $p K_{a}$ value of the $\mathrm{NO}_{2}^{-} / \mathrm{HNO}_{2}$ couple $\left(p K_{a}=3.29\right.$; Schwartz and White, 1981) is far below 7, this process releases relevant amounts of NO only under acidic conditions. The disproportionation of $\mathrm{HNO}_{2}$ can be described with Equation 2. The products- $\mathrm{NO}$ and $\mathrm{NO}_{2}$-are in equilibrium with $\mathrm{N}_{2} \mathrm{O}_{3}$ (Equation 5) which is an important agent for nitrosation (Bonner and Stedman, 1996). Under aerobic conditions, $\mathrm{NO}$ will be further oxidized to $\mathrm{NO}_{2}$. Since $\mathrm{NO}_{2}$ reacts with $\mathrm{H}_{2} \mathrm{O}$ to form $\mathrm{HNO}_{2}$ and $\mathrm{NO}_{3}^{-}$, the reaction scheme (Equations 2-4) is ultimately a chemical pathway for the oxidation of $\mathrm{NO}_{2}^{-}$to $\mathrm{NO}_{3}^{-}$.

$$
\begin{aligned}
& 2 \mathrm{HNO}_{2} \leftrightarrow \mathrm{NO}+\mathrm{NO}_{2}+\mathrm{H}_{2} \mathrm{O} \\
& \mathrm{NO}+0.5 \mathrm{O}_{2} \rightarrow \mathrm{NO}_{2} \\
& 2 \mathrm{NO}_{2}+\mathrm{H}_{2} \mathrm{O} \leftrightarrow \mathrm{HNO}_{2}+\mathrm{NO}_{3}^{-}+\mathrm{H}^{+} \\
& \mathrm{NO}+\mathrm{NO}_{2} \leftrightarrow \mathrm{N}_{2} \mathrm{O}_{3}
\end{aligned}
$$

Since the kinetic and equilibrium constants for Equations 2-5 are known, the production of NO can be calculated (Udert et al., 2005). Depending on the aeration intensity, substantial losses of nitrogen oxides can occur during chemical $\mathrm{HNO}_{2}$ oxidation. The stripped nitrogen oxides are mainly $\mathrm{HNO}_{2}$, but also $\mathrm{NO}$ is lost.

\section{IRON-MEDIATED REDUCTION OF N0-}

Ferrous iron $[\mathrm{Fe}(\mathrm{II})]$ can reduce $\mathrm{NO}_{2}^{-}$to $\mathrm{NO}$ and, in the second reaction step, $\mathrm{NO}$ to $\mathrm{N}_{2} \mathrm{O}$ (Kampschreur et al., 2011).

$$
\begin{array}{r}
\mathrm{NO}_{2}^{-}+\mathrm{Fe}^{2+}+2 \mathrm{H}^{+} \rightarrow \mathrm{Fe}^{3+}+\mathrm{NO}+\mathrm{H}_{2} \mathrm{O} \\
\Delta \mathrm{G}_{0}=35.8 \text { kJ reaction } \\
\\
\mathrm{NO}+\mathrm{Fe}^{2+}+\mathrm{H}^{+} \rightarrow \mathrm{Fe}^{3+}+0.5 \mathrm{~N}_{2} \mathrm{O}+0.5 \mathrm{H}_{2} \mathrm{O} \\
\Delta \mathrm{G}_{0}=-38.9 \mathrm{~kJ} \text { reaction }
\end{array}
$$

The first reaction is thermodynamically not possible under standard conditions, but in natural waters ferric iron [Fe(III)] will precipitate and thereby draw the Gibbs free energy to negative values. Iron-mediated reduction of $\mathrm{NO}_{2}^{-}$was described as one of the sources of $\mathrm{N}_{2} \mathrm{O}$ in soils (van Cleemput, 1998). Recently, Kampschreur et al. (2011) postulated that this process can contribute significantly to $\mathrm{N}_{2} \mathrm{O}$ production in wastewater treatment, if $\mathrm{NO}_{2}^{-}$and $\mathrm{Fe}(\mathrm{II})$ are present concomitantly. One example for such a system is nitrogen removal from anaerobic digester effluents via nitritation/denitrification or nitritation/anammox. Digester supernatants can contain high amounts of $\mathrm{Fe}(\mathrm{II})$, because iron salts are used to precipitate phosphate and $\mathrm{Fe}(\mathrm{II})$ will be released in the anaerobic digester due to the reducing conditions. Hu et al. (2001) reported an additional reaction of $\mathrm{NO}_{2}^{-}$with iron: under acidic conditions $\mathrm{NO}_{2}^{-}$is reduced in the presence of metallic iron to $\mathrm{N}_{2}$ and $\mathrm{NH}_{3}$. They propose a mechanism, in which metallic iron is oxidized at low $\mathrm{pH}$ releasing $\mathrm{Fe}^{2+}$ ions and molecular hydrogen $\left(\mathrm{H}_{2}\right) . \mathrm{NO}_{2}^{-}$is then reduced by $\mathrm{H}_{2}$ to $\mathrm{N}_{2}$ and $\mathrm{NH}_{3}$.

\section{OXIDATION OF $\mathrm{NH}_{2} \mathrm{OH}$ BY FE(III)}

Iron not only mediates $\mathrm{NO}$ and $\mathrm{N}_{2} \mathrm{O}$ production from $\mathrm{NO}_{2}^{-}$. As $\mathrm{Fe}(\mathrm{III})$, it also oxidizes $\mathrm{NH}_{2} \mathrm{OH}$ to $\mathrm{N}_{2} \mathrm{O}$. This process can be used for the analytical determination of trace amounts of $\mathrm{NH}_{2} \mathrm{OH}$ (Butler and Gordon, 1986a). The general equation for the reaction is

$$
4 \mathrm{Fe}(\mathrm{III})+2 \mathrm{NH}_{2} \mathrm{OH} \rightarrow 4 \mathrm{Fe}(\mathrm{II})+\mathrm{N}_{2} \mathrm{O}+\mathrm{H}_{2} \mathrm{O}+4 \mathrm{H}^{+}
$$

In this reaction, $\mathrm{N}_{2} \mathrm{O}$ formation strongly depends on the $\mathrm{pH}$ value. In experiments with distilled water and natural seawater, Butler and Gordon (1986b) found that at $\mathrm{pH} 3, \mathrm{~N}_{2} \mathrm{O}$ recovery was $80 \%$, while at a $\mathrm{pH}$ value of $9.5, \mathrm{~N}_{2} \mathrm{O}$ production was negligibly low. The authors hypothesized that at high $\mathrm{pH}$ values, $\mathrm{HNO}$, reacts with $\mathrm{O}_{2}$ to produce $\mathrm{NO}_{2}^{-}$and $\mathrm{H}_{2} \mathrm{O}$. However, it is also known that $\mathrm{HNO}$ can react with $\mathrm{NH}_{2} \mathrm{OH}$ to $\mathrm{N}_{2}$ (Bonner et al., 1978, Equation 10). Chemical production of $\mathrm{N}_{2} \mathrm{O}$ via $\mathrm{NH}_{2} \mathrm{OH}$ oxidation by $\mathrm{Fe}(\mathrm{III})$ is a likely process during nitrification, because $\mathrm{Fe}$ (III) compounds are ubiquitous in natural waters and wastewater treatment systems. 


\section{REACTION OF NH $\mathrm{OH}_{2}$ WITH $\mathrm{HNO}_{2}$ AND HNO}

Döring and Gehlen (1961) investigated the reaction of $\mathrm{NH}_{2} \mathrm{OH}$ and $\mathrm{HNO}_{2}$. They described the process as nitrosation of $\mathrm{NH}_{2} \mathrm{OH}$. The overall reaction can be written as

$$
\mathrm{NH}_{2} \mathrm{OH}+\mathrm{HNO}_{2} \rightarrow \mathrm{N}_{2} \mathrm{O}+2 \mathrm{H}_{2} \mathrm{O}
$$

In their reaction scheme, Döring and Gehlen (1961) included $\mathrm{H}_{2} \mathrm{~N}_{2} \mathrm{O}_{2}$ (the dimer of $\mathrm{HNO}$ ) as a direct precursor for $\mathrm{N}_{2} \mathrm{O}$. At neutral $\mathrm{pH}$ values, $\mathrm{N}_{2} \mathrm{O}_{3}$ is the relevant nitrosation agent. There are several reaction pathways for $\mathrm{N}_{2} \mathrm{O}_{3}$ formation from $\mathrm{HNO}_{2}$. Formation of $\mathrm{N}_{2} \mathrm{O}_{3}$ from $\mathrm{HNO}_{2}$ is given by Equations 2 and 5 . A kinetic constant for nitrosation of $\mathrm{NH}_{2} \mathrm{OH}$ is given by Döring and Gehlen (1961) and together with the kinetic constants for Equations 1 and 4 (Udert et al., 2005) the $\mathrm{N}_{2} \mathrm{O}$ production from $\mathrm{NH}_{2} \mathrm{OH}$ and $\mathrm{HNO}_{2}$ can be estimated. Some of the $\mathrm{NH}_{2} \mathrm{OH}$ can also react with the intermediate $\mathrm{HNO}$ to form $\mathrm{N}_{2}$ (Bonner et al., 1978)

$$
\mathrm{HNO}+\mathrm{NH}_{2} \mathrm{OH} \rightarrow \mathrm{N}_{2}+2 \mathrm{H}_{2} \mathrm{O}
$$

\section{DISPROPORTIONATION OF $\mathrm{NH}_{2} \mathrm{OH}$}

The disproportionation of $\mathrm{NH}_{2} \mathrm{OH}$ can be described with the following equation (Bonner et al., 1978):

$$
4 \mathrm{NH}_{2} \mathrm{OH} \rightarrow 2 \mathrm{NH}_{3}+\mathrm{N}_{2} \mathrm{O}+\mathrm{H}_{2} \mathrm{O}
$$

In pure water, this process is very slow with slightly higher degradation rates at elevated $\mathrm{pH}$ values. At $\mathrm{pH} 3$ and $25 \pm 3^{\circ} \mathrm{C}$, Bonner et al. (1978) observed no $\mathrm{NH}_{2} \mathrm{OH}$ disproportionation over 2 months, while $12-18 \%$ of the $\mathrm{NH}_{2} \mathrm{OH}$ was degraded over 2 months at $\mathrm{pH}$ 13.5. Complexes of transition metals can accelerate $\mathrm{NH}_{2} \mathrm{OH}$ disproportionation considerably (Alluisetti et al., 2004). Jenni et al. (2012) also observed $\mathrm{N}_{2} \mathrm{O}$ formation within minutes, although the experiment was conducted in a phosphate buffer solution without transition metals. The disproportionation might have been catalyzed by the steel surface of an electrode immersed in the reactor, but this hypothesis still has to be proven.

\section{AUTOXIDATION OF $\mathrm{NH}_{2} \mathrm{OH}$}

Oxidation of $\mathrm{NH}_{2} \mathrm{OH}$ with $\mathrm{O}_{2}$ (autoxidation, Equation 12) is a slow process, although faster than $\mathrm{NH}_{2} \mathrm{OH}$ disproportionation.

$$
2 \mathrm{NH}_{2} \mathrm{OH}+\mathrm{O}_{2} \rightarrow \mathrm{N}_{2} \mathrm{O}+3 \mathrm{H}_{2} \mathrm{O}
$$

Again, trace concentrations of metals can strongly accelerate the process. Anderson (1964) reported that in an aerated solution with $1 \mathrm{mmol} \cdot \mathrm{L}^{-1} \mathrm{NH}_{2} \mathrm{OH}$ and $1 \mu \mathrm{mol} \cdot \mathrm{L}^{-1}$ cupric sulfate $30 \%$ of the $\mathrm{NH}_{2} \mathrm{OH}$ was oxidized within $1 \mathrm{~h}$, while only $2.5 \%$ were degraded without cupric sulfate addition $(\mathrm{pH}$ between 7.8 and $\left.7.9,30^{\circ} \mathrm{C}\right) . \mathrm{Cu}$ is by far the most potent catalyzer for the autooxidation of $\mathrm{NH}_{2} \mathrm{OH}$ followed by $\mathrm{Co}(\mathrm{II}), \mathrm{Fe}(\mathrm{II}), \mathrm{Mn}(\mathrm{II})$, and $\mathrm{Zn}$ (II) (Moews and Audrieth, 1959). Since most wastewaters and natural waters contain some traces of metals, autoxidation of hydroxylamine cannot a priori be excluded as a source of $\mathrm{N}_{2} \mathrm{O}$.

\section{HNO AS INTERMEDIATE OF ENZYMATIC $\mathrm{NH}_{2} \mathrm{OH}$ OXIDATION}

Several authors postulated that $\mathrm{HNO}$ was a likely intermediate of $\mathrm{HAO}$ due to the observed $\mathrm{N}_{2} \mathrm{O}$ production (Anderson, 1964;
Ritchie and Nicholas, 1972). Igarashi et al. (1997) could show that the crystal structure of HAO in Nitrosomonas europaea is in agreement with the following two step reaction

$$
\begin{aligned}
\mathrm{NH}_{2} \mathrm{OH} & \rightarrow(\mathrm{HNO})+2 \mathrm{H}^{+}+2 \mathrm{e}^{-} \\
(\mathrm{HNO})+\mathrm{H}_{2} \mathrm{O} & \rightarrow \mathrm{HNO}_{2}+2 \mathrm{H}^{+}+2 \mathrm{e}^{-}
\end{aligned}
$$

Based on this scheme, an imbalance of the two reaction steps could lead to an accumulation of $\mathrm{HNO}$ and subsequently to chemical $\mathrm{N}_{2} \mathrm{O}$ production (Equation 1). Law et al. (2012) developed four different metabolic computer models to elucidate the mechanisms of aerobic $\mathrm{N}_{2} \mathrm{O}$ production in a nitritation reactor. The best fit of the measurement data was achieved with a model based on chemical HNO production. The other models, which represented three different metabolic pathways for the enzymatic reduction of nitrite and $\mathrm{NO}$ to $\mathrm{N}_{2} \mathrm{O}$, could not reproduce the measurement data satisfactorily. Indeed, we think that the positive SP of $\mathrm{N}_{2} \mathrm{O}$ produced during $\mathrm{NH}_{2} \mathrm{OH}$ oxidation can be explained by a kinetic isotope effect acting during the chemical cleavage of a symmetric intermediate such as $\mathrm{H}_{2} \mathrm{~N}_{2} \mathrm{O}_{2}$ formed by dimerization of two HNO molecules (Equation 1; Toyoda et al., 2005). In addition, the studies of Law et al. (2012) and of Udert et al. (2005) exemplify that computer models are powerful tools to elucidate the mechanisms of $\mathrm{N}_{2} \mathrm{O}$ and $\mathrm{NO}$ production, especially when the processes contain microbial as well as chemical reaction steps.

\section{RELEVANT ENVIRONMENTS FOR CHEMICAL REACTIONS}

In the last years, nitrogen treatment of high-strength wastewaters such as digester supernatant, manure and urine have received considerable attention. Based on our literature review, these systems are particularly prone to chemical production of $\mathrm{NO}$ and $\mathrm{N}_{2} \mathrm{O}$ because of high $\mathrm{NH}_{3}$ oxidation rates and high concentrations of the intermediate $\mathrm{NH}_{2} \mathrm{OH}$. Furthermore, some treatment schemes include $\mathrm{NO}_{2}^{-}$accumulation as a process step, for example SHARON ${ }^{\circledR}$. Ubiquitous iron compounds, e.g., from phosphate precipitation or as sensors and reactor walls, are another factor that can support the production of $\mathrm{NO}$ and $\mathrm{N}_{2} \mathrm{O}$. At the current stage of knowledge, it is hard to estimate the contribution of chemical processes to the overall $\mathrm{NO}$ and $\mathrm{N}_{2} \mathrm{O}$ production. Many chemical processes have been described, but with the exception of $\mathrm{HNO}_{2}$ disproportionation and the reaction of $\mathrm{HNO}_{2}$ with $\mathrm{NH}_{2} \mathrm{OH}$, the kinetic data are insufficient for a reliable prediction of the production rates. Chemical production of $\mathrm{NO}$ and $\mathrm{N}_{2} \mathrm{O}$ can also occur in natural environments, where high ammonia inputs meet low $\mathrm{pH}$ values such as strongly fertilized soils (van Cleemput and Samater, 1996) or poorly buffered lakes (Schuurkes and Mosello, 1988). Furthermore, chemical oxidation of NO and $\mathrm{N}_{2} \mathrm{O}$ is an important process in the atmosphere (Lammel and Cape, 1996).

\section{NO AND $\mathrm{N}_{2} \mathrm{O}$ FORMATION IN NATURAL ENVIRONMENTS NITRIC OXIDE}

NO production and consumption has been studied in soils. The studies used inhibition of nitrification with low concentrations of acetylene $(\sim 10 \mathrm{~Pa})$ to distinguish between NO turnover by nitrification and denitrification, assuming that acetylene does not inhibit $\mathrm{N}_{2} \mathrm{O}$ reductase at these concentrations. $\mathrm{O}_{2}$ availability, as 
regulated by soil moisture content, is the main factor controlling the mechanisms of NO release (Bollmann and Conrad, 1998). While denitrification is the only process that releases NO under anoxic conditions, nitrification dominates $\mathrm{NO}$ release under oxic conditions with highest rates at low $\mathrm{O}_{2}$ concentrations. In addition, soil $\mathrm{pH}, \mathrm{NH}_{4}^{+}, \mathrm{NO}_{3}^{-}, \mathrm{NO}_{2}^{-}$, and respiration are important soil variables that affect NO turnover (Gödde and Conrad, 2000).

Measurements of NO in seawater are rare, because concentrations are low and turnover is fast due to its reactivity. However, Zafiriou et al. (1980) found that surface water of the central equatorial Pacific is a NO source to the atmosphere. Here, NO is formed by photolysis of $\mathrm{NO}_{2}^{-}$during daytime and reaches concentrations in the picomolar range (Zafiriou and True, 1979). Moreover, $\mathrm{NO}$ is formed by microbial processes in the $\mathrm{O}_{2} \mathrm{~min}$ imum zone of the eastern tropical North Pacific (Ward and Zafiriou, 1988). Here, maximum NO turnover and concentration coincide with low $\mathrm{O}_{2}$ concentrations $\left(10-100 \mu \mathrm{mol} \mathrm{L}^{-1}\right)$ and some nitrification activity overlying the $\mathrm{O}_{2}$ minimum zone. In contrast, $\mathrm{NO}$ turnover and concentrations are low in the core of the $\mathrm{O}_{2}$ minimum zone. The exact source of $\mathrm{NO}$ remained unidentified, but it was hypothesized that nitrifiers produce NO under reduced $\mathrm{O}_{2}$ concentrations and that denitrifiers establish rather low $\mathrm{NO}$ concentrations in the core of the $\mathrm{O}_{2}$ minimum zone. $\mathrm{NO}$ formation has been measured in marine sediments (Schreiber et al., 2008) and a more detailed study of NO turnover has been performed in freshwater sediments (Schreiber et al., unpublished results). Both studies will be discussed in the section focusing on microelectrodes.

\section{NITROUS OXIDE}

Generally, $\mathrm{N}_{2} \mathrm{O}$ formation has been investigated to greater detail and in a wider variety of habitats as compared to NO, because it is an environmental impact is considered to be stronger than that of NO and its turnover is easier to measure due to its chemical stability. At present, anthropogenic $\mathrm{N}_{2} \mathrm{O}$ emissions account for $\sim 40 \%$ of the global $\mathrm{N}_{2} \mathrm{O}$ emissions (Montzka et al., 2011). Current estimates state that $\sim 50 \%$ of the anthropogenic $\mathrm{N}_{2} \mathrm{O}$ is emitted from soils (Stein and Yung, 2003), 10\% from estuaries and freshwater habitats (Beaulieu et al., 2011) and 3.2\% are emitted from wastewater treatment plants (WWTP) (Kampschreur et al., 2009). We caution that future adjustments to these estimates are likely, and that these averages do not capture the high variability in emissions from selected environments. Recent work has suggested that emissions from WWTPs in particular are highly variable and may in some cases be up to an order of magnitude greater than previous estimates (Ahn et al., 2010; Lotito et al., 2012). Soils and aquatic habitats exposed to intense agricultural activities are the largest sources due to high $\mathrm{N}$-input through fertilization. Since mixed microbial communities in soils are the largest anthropogenic source for $\mathrm{N}_{2} \mathrm{O}$, its formation has been intensively studied and was recently reviewed (Baggs, 2011). $\mathrm{N}_{2} \mathrm{O}$ formation in WWTP has been reviewed by Kampschreur et al. (2009).

The ocean is an important source of $\mathrm{N}_{2} \mathrm{O}$ accounting for $\sim 30 \%$ of the natural $\mathrm{N}_{2} \mathrm{O}$ emission (Stein and Yung, 2003). Large areas of the ocean are thought to be in equilibrium with the atmosphere, but regions of $\mathrm{O}_{2}$ depletion are significant sources of $\mathrm{N}_{2} \mathrm{O}$
(Elkins et al., 1978). In $\mathrm{O}_{2}$ minimum zones, $\mathrm{N}_{2} \mathrm{O}$ is generally produced to concentrations in the nanomolar range as $\mathrm{O}_{2}$ reaches low concentrations (Yoshida et al., 1989; Naqvi et al., 2000; Farias et al., 2007; Nicholls et al., 2007). High $\mathrm{N}_{2} \mathrm{O}$ accumulation was observed in surface water of the Arabian Sea and explained with frequent, turbulence-induced aeration of suboxic surface water (Naqvi et al., 2000). Likewise, $\mathrm{O}_{2}$ fluctuations, induced by the El Nino-Southern oscillation, have been proposed to affect $\mathrm{N}_{2} \mathrm{O}$ emission from the $\mathrm{O}_{2}$ minimum zone of the eastern South Pacific (Farias et al., 2007). Furthermore, marine and freshwater sediments emit $\mathrm{N}_{2} \mathrm{O}$ (Meyer et al., 2008; Nielsen et al., 2009). NO and $\mathrm{N}_{2} \mathrm{O}$ formation in sediments will be discussed in more detail in the section focusing on microelectrodes.

The occurrence of animals such as earthworms (Horn et al., 2003 ) in soils and macrofauna in fresh -or seawater habitats (Stief et al., 2009; Heisterkamp et al., 2010) enhances the emission of $\mathrm{N}_{2} \mathrm{O}$ in response to anthropogenic $\mathrm{N}$-input. These animals ingest denitrifying bacteria and stimulate their activity probably with delayed expression of $\mathrm{N}_{2} \mathrm{O}$ reduction leading to enhanced $\mathrm{N}_{2} \mathrm{O}$ emissions.

\section{EXPERIMENTAL APPROACHES}

In most investigated habitats $\mathrm{NO}$ and $\mathrm{N}_{2} \mathrm{O}$ formation has been attributed to the $\mathrm{NH}_{2} \mathrm{OH}$ pathway by $\mathrm{AOB}$, nitrifier denitrification and heterotrophic denitrification. There are three approaches to determine the contribution of the different pathways:

(1) Indirect inference of pathways by excluding the activity of all other possible pathways, which can be achieved by using inhibitors or by removing the substrate (Kampschreur et al., 2008b; Schreiber et al., 2009; Stief et al., 2009; Wunderlin et al., 2012).

(2) Measuring the isotopic signature of $\mathrm{N}_{2} \mathrm{O}\left({ }^{15} \mathrm{~N}\right.$ natural abundance or SP) and comparing the data to values of pure cultures (Yoshida, 1988; Yoshida et al., 1989; Sutka et al., 2006; Well et al., 2006; Charpentier et al., 2007; Wunderlin et al., unpublished results).

(3) Application of ${ }^{15} \mathrm{~N}$ isotopically-enriched substrates and mass spectrometric measurements of $\mathrm{N}_{2} \mathrm{O}$ (Bateman and Baggs, 2005; Baggs, 2008).

In complex systems all of these approaches suffer from the coupled nature of nitrification and denitrification. This especially applies to studies where bulk measurements have been done even though micro-environmental heterogeneities are expected; e.g., in aggregates in wastewater treatment systems or in soil particles. In addition, it has become clear that $\mathrm{NO}$ and $\mathrm{N}_{2} \mathrm{O}$ are dynamically produced in response to changing environmental conditions (Kampschreur et al., 2008b; Schreiber et al., 2009). Transient NO and $\mathrm{N}_{2} \mathrm{O}$ concentrations can be orders of magnitude higher than under steady state. Conventional mass spectrometric measurements do not allow measurements with high temporal and spatial resolution, making approach 2 and 3 inaccessible to microscale and dynamic analysis of $\mathrm{NO}$ and $\mathrm{N}_{2} \mathrm{O}$.

\section{NOVEL ANALYTICAL METHODS}

In the following sections, we will discuss different analytical methods (microelectrodes, mass spectrometry, and QCLAS) that 
can be used to allocate $\mathrm{NO}$ and $\mathrm{N}_{2} \mathrm{O}$ production to certain pathways by using one of the three approaches outlined above. Combining these methods and thus the different approaches will lead to a more firm pathway allocation. Microelectrodes can measure with high temporal and spatial resolution and in combination with other microelectrodes $\left(\mathrm{NH}_{4}^{+}, \mathrm{NO}_{3}^{-}, \mathrm{NO}_{2}^{-}\right.$, and $\left.\mathrm{O}_{2}\right)$ approach 1 can be used to allocate source pathways. Further, QCLAS can measure the SP in $\mathrm{N}_{2} \mathrm{O}$ dynamically and can be used to allocate $\mathrm{N}_{2} \mathrm{O}$ production pathways with approach 2 . In addition, we will discuss the potential for other techniques that measure the isotopic composition of $\mathrm{N}_{2} \mathrm{O}$ and molecular methods to aid the understanding of $\mathrm{NO}$ and $\mathrm{N}_{2} \mathrm{O}$ formation in complex environments.

\section{MICROELECTRODES TO CAPTURE MICRO-ENVIRONMENTAL DISTRIBUTION AND TEMPORAL DYNAMICS OF NO AND $\mathrm{N}_{2} \mathrm{O}$ \\ NO AND $\mathrm{N}_{2} \mathrm{O}$ MICROELECTRODES}

Microelectrodes belong to the tool box of microbial ecologists since Revsbech et al. introduced an $\mathrm{O}_{2}$ microelectrode in the early 1980s (Revsbech et al., 1980). The first $\mathrm{N}_{2} \mathrm{O}$ microelectrode for microbial ecology (Revsbech et al., 1988) was a combined $\mathrm{O}_{2} / \mathrm{N}_{2} \mathrm{O}$ sensor where an $\mathrm{O}_{2}$-reducing gold cathode was placed in front of an $\mathrm{N}_{2} \mathrm{O}$-reducing silver cathode (both polarized at $-800 \mathrm{mV}$ ) to avoid the interference of $\mathrm{O}_{2}$ with $\mathrm{N}_{2} \mathrm{O}$ detection. These sensors where difficult to manufacture and had a short life-time. Thus, Andersen et al. (2001) introduced an improved $\mathrm{O}_{2}$-insensitive $\mathrm{N}_{2} \mathrm{O}$ microelectrode. Insensitivity to $\mathrm{O}_{2}$ is achieved by placing a reservoir filled with alkaline ascorbate solution for the chemical reduction of $\mathrm{O}_{2}$ in front of the $\mathrm{N}_{2} \mathrm{O}$ reducing cathode, which is separated from the ascorbate reservoir with a gas permeable silicone membrane. These $\mathrm{N}_{2} \mathrm{O}$ microelectrodes have a sensitivity of $\sim 0.5 \mu \mathrm{mol} \mathrm{L}^{-1}$ and a spatial resolution of $\sim 60 \mu \mathrm{m}$.

Electrochemical NO sensors for the detection of NO in biological systems are available since the early 1990s (Shibuki, 1990). Amperometric sensing of $\mathrm{NO}$ is commonly achieved by the oxidation of $\mathrm{NO}$ at a working electrode polarized with $0.7-0.9 \mathrm{~V}$ vs. a reference electrode $(\mathrm{Ag} / \mathrm{AgCl}$ or Calomel) leading to the following anodic reaction:

$$
\mathrm{NO}+2 \mathrm{H}_{2} \mathrm{O}-3 \mathrm{e}^{-} \rightarrow \mathrm{NO}_{3}^{-}+4 \mathrm{H}^{+}
$$

The resulting current is proportional to the NO concentration and can be detected as the analytical signal. Electrodes are reported as single anode-type electrodes or as combined sensors (Figure 2). In combined sensors, the reference electrode and the sensing electrode are placed together in an internal electrolyte compartment that is separated from the sample by a gas permeable, non-conductive membrane (Clark-type, Figure 2B), whereas single anode-type electrodes use the aqueous sample as an electrolyte and complete the measuring circuit by submerging an external reference electrode into it (Figure 2A). Charged interferences like $\mathrm{NO}_{2}^{-}$and ascorbate are typically repelled by constructing combined sensors with hydrophobic membranes like chloroprene (Shibuki, 1990), PTFE (Teflon ${ }^{\mathrm{TM}}$ ) (Lee et al., 2004), sol-gels (Shin et al., 2005), polystyrene (Kitamura et al.,
A

\section{Single-anode sensor}

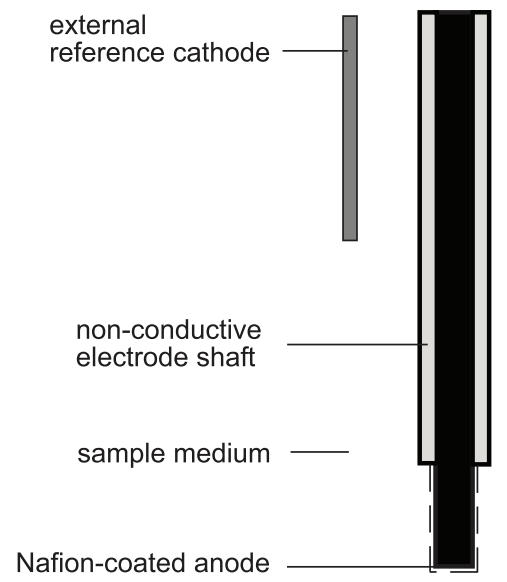

FIGURE 2 | NO microelectrodes. (A) Depicts a typical single-anode type NO sensor with a long sensing anode, which is coated with Nafion to confer selectivity against charged interferences. The anode and reference cathode are directly emerged into the sample medium. Some sensor designs integrate the cathode into the electrode shaft. (B) Depicts the NO
B Combined sensor

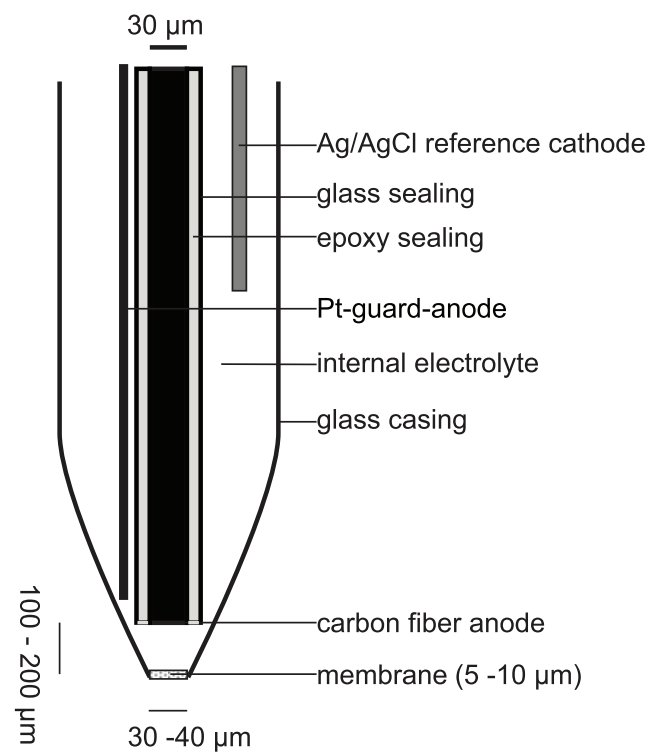

microelectrode for measurements in biofilms and sediments as reported by Schreiber et al. (2008). This sensor is also an example for a combined NO sensor (Clark-type) where sensing anode and reference cathode are separated from the sample medium by a gas permeable membrane. Drawing is not to scale. 
2000) or silicone (Schreiber et al., 2008), or by depositing conductive Nafion ${ }^{\mathrm{TM}}$ on single anode-type electrodes (Malinski and Taha, 1992; Friedemann et al., 1996; Bedioui and Villeneuve, 2003).

Most of the previously described NO electrodes have been optimized to detect NO at low nanomolar or even picomolar concentration. This has been achieved by increasing the sensing surface with a subsequent loss of spatial resolution. Single-anodetype sensors commonly rely on carbon-fibers that have a length of up to several millimeters and combined sensors have openings in the high micrometer to millimeter range. Microelectrodes with long, exposed sensing surfaces are not applicable for profiling in stratified microbial systems because the concentration of the analyte might change along the sensing surface. The obtained signal is then an integrated measure of the concentrations along the electrode. Similarly, combined electrodes with wide openings are also problematic for profiling applications, since the step size of different measurement points in a depth profile should not be smaller than two times the outer diameter of the electrode (Gieseke and de Beer, 2004). In addition, single-anode sensors are not robust enough to be inserted in a sturdy sediment or soil sample since the particles will damage the Nafion ${ }^{\mathrm{TM}}$ membrane that confers selectivity against $\mathrm{NO}_{2}^{-}$. Consequently, applications of NO electrodes-commercially supplied, e.g., by World Precision Instruments (Sarasota, Florida, USA) — in microbiology were restricted to detection of NO in pure culture suspensions (e.g., Corker and Poole, 2003).

Recently, an NO microelectrode was introduced that is applicable to study complex, stratified microbial communities in sediments and biofilms (Schreiber et al., 2008). The NO microelectrode is a combined (Clark-type) sensor with a carbon-fiber anode $(+750 \mathrm{mV})$ placed behind a gas permeable silicon membrane (Figure 2B). The sensor has a detection limit of $0.030 \mu \mathrm{mol}$ $\mathrm{L}^{-1}$ and a spatial resolution of $\sim 60 \mu \mathrm{m}$. Thus, the sensor is optimized to provide sufficient sensitivity for NO concentrations produced in complex, $\mathrm{N}$-cycling microbial communities and sufficient spatial resolution to measure in microbial biofilms, sediments and soils. The robust Clark-type design allows measurements in sturdy soil and sediment samples. It has been made commercially available through Unisense A/S (Arhus, Denmark), who also supplies $\mathrm{N}_{2} \mathrm{O}$ microelectrodes.

\section{INTERFERENCES}

$\mathrm{H}_{2} \mathrm{~S}$ interferes with $\mathrm{NO}$ measurement as it passes the silicone membrane and is readily oxidized at the sensing anode. A sensitive $\mathrm{H}_{2} \mathrm{~S}$ microsensor (Jeroschewski et al., 1996) should thus be used to rule out any interference of $\mathrm{H}_{2} \mathrm{~S}$ in the measurements or -if possible- experiments must be designed to avoid active sulfate reduction in the sample by excluding sulfate from the medium. Jenni et al. (2012) investigated the interferences of $\mathrm{CO}_{2}, \mathrm{O}_{2}$, and various nitrogen compounds commonly found in wastewater treatment on $\mathrm{NO}$ and $\mathrm{N}_{2} \mathrm{O}$ sensors. They found that $\mathrm{NO}$ interfered with the $\mathrm{N}_{2} \mathrm{O}$ measurement, while the $\mathrm{NO}$ sensors were sensitive on $\mathrm{NH}_{3}, \mathrm{NH}_{2} \mathrm{OH}, \mathrm{HNO}_{2}$, and $\mathrm{N}_{2} \mathrm{H}_{4}$. If high concentrations of these compounds are expected, it is recommended to check the concentrations of interfering compounds. No significant interferences were found by $\mathrm{CO}_{2}$ and $\mathrm{O}_{2}$. The cross-sensitivities can be corrected with calibration curves that are determined before the experiments. Jenni et al. (2012) also reported a significant temperature dependency. The NO signal increased by about $3.5 \%$ per $1^{\circ} \mathrm{C}$ and the $\mathrm{N}_{2} \mathrm{O}$ signal by $3.9 \%$ per $1^{\circ} \mathrm{C}$. The temperature dependencies can be corrected with exponential functions.

\section{APPLICATION OF NO MICROELECTRODES}

The novel NO microelectrode has been applied to study NO formation in permeable marine (Schreiber et al., 2008) and river (Schreiber et al., unpublished results) sediments. The results showed that in steady-state $\mathrm{NO}$ is produced in oxic/micro-oxic sediment strata reaching concentrations of $0.13 \mu \mathrm{mol} \mathrm{L}^{-1}$ in river and $0.5 \mu \mathrm{mol} \mathrm{L}^{-1}$ in marine sediments. In both sediments, NO produced in the oxic zone was consumed in the anoxic zone. It was hypothesized that $\mathrm{NO}$ was produced by $\mathrm{AOB}$ in the oxic zone. Labeling experiments with a ${ }^{15} \mathrm{~N}$-labeled $\mathrm{NO}$ donor in the river sediment suggested that denitrification actively consumes exogenously produced NO.

Furthermore, the NO microelectrodes have been applied together with $\mathrm{N}_{2} \mathrm{O}$ microelectrodes in two $\mathrm{N}$-cycling microbial biofilms; namely a complex $\mathrm{NH}_{4}^{+}$-fed biofilm with nitrifying and denitrifying activity (Schreiber et al., 2009) and human dental plaque that was naturally exposed to high $\mathrm{NO}_{3}^{-}$and $\mathrm{NO}_{2}^{-}$in saliva (Schreiber et al., 2010). The study in dental plaque showed that plaque denitrified under aerobic conditions, that $\mathrm{NO}$ and $\mathrm{N}_{2} \mathrm{O}$ was produced by denitrification and that $\mathrm{NO}$ and $\mathrm{N}_{2} \mathrm{O}$ concentrations increased with decreasing $\mathrm{pH}$. Aerobic denitrification has also been reported from permeable marine sediments (Gao et al., 2010) and from isolated (Patureau et al., 2000) or extracted soil bacteria (Morley et al., 2008). Until now, it is not known in which environments aerobic denitrification plays an important role, and if it is an environmentally significant $\mathrm{NO}$ and $\mathrm{N}_{2} \mathrm{O}$ emission pathway. $\mathrm{NO}, \mathrm{N}_{2} \mathrm{O}, \mathrm{NO}_{2}^{-}, \mathrm{NO}_{3}^{-}$, and $\mathrm{O}_{2}$ microelectrodes will be crucial to determine the importance of aerobic denitrification for $\mathrm{NO}$ and $\mathrm{N}_{2} \mathrm{O}$ release for complex ecosystems, because these sensors allow the simultaneous detection of $\mathrm{NO}, \mathrm{N}_{2} \mathrm{O}, \mathrm{NO}_{2}^{-}$, $\mathrm{NO}_{3}^{-}$, and $\mathrm{O}_{2}$ concentrations at high spatial resolution and their relation to denitrification activity.

Studying a complex $\mathrm{N}$-cycling biofilm revealed the dynamics of $\mathrm{NO}$ and $\mathrm{N}_{2} \mathrm{O}$ formation upon perturbations in a system where nitrification and denitrification co-exist (Schreiber et al., 2009). The concomitant use of an $\mathrm{O}_{2}$ microelectrode and a set of control experiments enabled assignment of $\mathrm{NO}$ and $\mathrm{N}_{2} \mathrm{O}$ formation under oxic conditions to $\mathrm{AOB}$ and under anoxic conditions to denitrifiers. It also showed that $\mathrm{AOB}$ produce $\mathrm{NO}$ and $\mathrm{N}_{2} \mathrm{O}$ under fully oxic conditions if $\mathrm{NO}_{2}^{-}$concentrations are high. This is in agreement with other observations (Beaumont et al., 2004a,b; Shaw et al., 2006) and contradicts the assumption that that AOB require low $\mathrm{O}_{2}$ to release $\mathrm{NO}$ and $\mathrm{N}_{2} \mathrm{O}$ (Lipschultz et al., 1981; Poth and Focht, 1985; Kester et al., 1997; Beaumont et al., 2004a; Kampschreur et al., 2008b). The high temporal resolution of the microelectrodes allow to detect transient bursts (seconds to minutes) of $\mathrm{NO}$ and $\mathrm{N}_{2} \mathrm{O}$. The bursts occurred by $\mathrm{AOB}$ upon $\mathrm{O}_{2}$ removal and upon $\mathrm{NO}_{2}^{-}$addition by both $\mathrm{AOB}$ and denitrifiers. The bursts only occurred if the perturbations were exerted upon metabolically active $\mathrm{AOB}$ and denitrifiers. In both scenarios $\mathrm{NO}$ and $\mathrm{N}_{2} \mathrm{O}$ are formed in parallel confirming that $\mathrm{NO}$ is the 
preceding intermediate of $\mathrm{N}_{2} \mathrm{O}$ in the $\mathrm{N}_{2} \mathrm{O}$ production pathways in this biofilm. An important contribution by Yu et al. (2010) showed that an AOB pure culture accumulated only NO, not $\mathrm{N}_{2} \mathrm{O}$, upon transition from oxic to anoxic conditions. In mixed microbial communities were $\mathrm{AOB}$ and heterotrophic denitrifiers co-exist this could lead to NO release by AOB and immediate reduction to $\mathrm{N}_{2} \mathrm{O}$ by heterotrophic denitrifiers or anaerobic detoxification via NorVW and Hmp. This mixed source of $\mathrm{N}_{2} \mathrm{O}$ during transient oxic to anoxic conditions has to be taken into account when determining the pathways with isotopic techniques. It has been argued that $\mathrm{N}_{2} \mathrm{O}$ transiently accumulates during transition from anoxic to oxic conditions because $\mathrm{O}_{2}$ inhibits Nos while denitrification still proceeds, but direct evidence for this hypothesis is weak. Using both $\mathrm{NO}$ and $\mathrm{N}_{2} \mathrm{O}$ microelectrodes would allow to test this because $\mathrm{N}_{2} \mathrm{O}$ accumulation should not be accompanied by $\mathrm{NO}$ accumulation if the denitrification sequence is inhibited at the level of Nos.

\section{APPLICATION OF $\mathrm{N}_{\mathbf{2}} \mathrm{O}$ MICROELECTRODES}

In many habitats steady-state $\mathrm{N}_{2} \mathrm{O}$ concentrations are below or at the detection limit of the $\mathrm{N}_{2} \mathrm{O}$ microelectrode. Thus, the $\mathrm{N}_{2} \mathrm{O}$ microelectrode has commonly been used to estimate the denitrification potentials in stratified microbial communities such as sediments, biofilms, and aggregates in combination with the acetylene inhibition technique (Revsbech et al., 1988). Acetylene $(\sim 10 \mathrm{kPa})$ inhibits $\mathrm{N}_{2} \mathrm{O}$ reductase and leads to the accumulation of high amounts of $\mathrm{N}_{2} \mathrm{O}$.

More recently, $\mathrm{N}_{2} \mathrm{O}$ microelectrodes have been used to study $\mathrm{N}_{2} \mathrm{O}$ production without acetylene inhibition in natural samples. These studies revealed that $\mathrm{N}_{2} \mathrm{O}$ concentrations in the micromolar range are expected when the system is exposed to a perturbation (Table 1). Transient accumulation of high $\mathrm{N}_{2} \mathrm{O}$ concentrations were achieved by any perturbation that affects the ambient $\mathrm{O}_{2}$ concentration: flooding of soils with water (Liengaard et al., 2011; Markfoged et al., 2011), creating an organic hotspot around a soil aggregate (Hojberg et al., 1994), thawing of permafrost soils (Elberling et al., 2010), and decreasing the $\mathrm{O}_{2}$ supply to wastewater-grown biofilms (Kampschreur et al., 2008a,b; Schreiber et al., 2009; Pellicer-Nàcher et al., 2010). In addition, increased input of $\mathrm{NO}_{3}^{-}, \mathrm{NO}_{2}^{-}$or $\mathrm{NH}_{4}^{+}$ to sediments, soils and biofilms (Hojberg et al., 1994; Meyer et al., 2008; Nielsen et al., 2009; Schreiber et al., 2009), organic inputs, salinity fluctuations in sediments (Nielsen et al., 2009) and changes of $\mathrm{pH}$ due to microbial activity in a denitrifying, dental biofilm (Schreiber et al., 2010) lead to increased micro-environmental $\mathrm{N}_{2} \mathrm{O}$ levels. Importantly, in many of these studies $\mathrm{N}_{2} \mathrm{O}$ accumulated in a transient manner making timecourse measurements necessary to capture the $\mathrm{N}_{2} \mathrm{O}$ peak and the accumulation time span. The high spatial resolution of the $\mathrm{N}_{2} \mathrm{O}$ microelectrode allowed allocating processes that mitigate the emission of $\mathrm{N}_{2} \mathrm{O}$ to the atmosphere in soils, sediments and wastewater treatment biofilms. $\mathrm{N}_{2} \mathrm{O}$ that is produced by denitrification in deeper layers and is consumed during its diffusion toward the sediment-water interface in nutrient-enriched mangrove sediments (Meyer et al., 2008), toward the soil-atmosphere interface in a thawed permafrost soil (Elberling et al., 2010) or in a soil aggregate exposed to an organic hotspot (Hojberg et al., 1994). Likewise, $\mathrm{N}_{2} \mathrm{O}$ release from a membrane-aerated biofilm reactor was minimized by $\mathrm{N}_{2} \mathrm{O}$-reducing microbes placed above $\mathrm{AOB}$ that produced $\mathrm{N}_{2} \mathrm{O}$ due to perturbations induced by an intermittent aeration regime (Pellicer-Nàcher et al., 2010).

\section{OUTLOOK}

From the investigations of transient $\mathrm{NO}$ and $\mathrm{N}_{2} \mathrm{O}$ accumulation it emerges that two scenarios with distinct dynamics are important. First, $\mathrm{N}_{2} \mathrm{O}$ accumulates over hours to days, because it mirrors the onset of denitrification activity. Depending on the system it decreases because $\mathrm{N}_{2} \mathrm{O}$ reduction pathways are turned on with a delay or denitrification activity decreases due to substrate limitation. Ahn et al. (2011) even observed that peak $\mathrm{NO}$ and $\mathrm{N}_{2} \mathrm{O}$ emissions after a shift to $\mathrm{O}_{2}$-limitation in a nitrifying reactor were lasting for several month before adaptation on the metabolic or community level decreased the emissions. Second, perturbation of active $\mathrm{AOB}$ or denitrifiers leads to burst-like (within seconds to minutes) release of $\mathrm{NO}$ and $\mathrm{N}_{2} \mathrm{O}$. The exact biochemical mechanisms for this require further research directly on the involved enzymes. Moreover, future research must show the contributions of the two types of transitions to the $\mathrm{N}_{2} \mathrm{O}$ budget and could use this as a framework to mitigate peak $\mathrm{N}_{2} \mathrm{O}$ releases to the atmosphere. Mitigation strategies could aid at avoiding perturbations or confining the $\mathrm{N}_{2} \mathrm{O}$-releasing processes into a diffusion-limited environment that is overlaid with $\mathrm{N}_{2} \mathrm{O}$-consuming microbial communities.

\section{$\mathrm{N}_{2} \mathrm{O}$ SOURCE PARTITIONING BASED ON THE NITROGEN AND OXYGEN ISOTOPIC SIGNATURE}

In recent years, the isotopic signature of $\mathrm{N}_{2} \mathrm{O}$ has been used as a powerful tool to assign $\mathrm{N}_{2} \mathrm{O}$ production pathways to $\mathrm{AOB}$ and heterotrophic denitrifiers in different ecosystems such as soils, rivers, sea, wastewater treatment (Yoshida et al., 1989; Yamagishi et al., 2007; Baggs, 2008; Koba et al., 2009; Baulch et al., 2011; Park et al., 2011; Toyoda et al., 2011). $\mathrm{N}_{2} \mathrm{O}$ is a linear molecule $\left(\mathrm{N}^{\beta}-\mathrm{N}^{\alpha}-\mathrm{O}\right)$ with one nitrogen atom at the center position $\left(\mathrm{N}^{\alpha}\right)$ bound to oxygen, and one at the end position $\left(\mathrm{N}^{\beta}\right)$ bound to $\mathrm{N}^{\alpha}$. The three most abundant $\mathrm{N}_{2} \mathrm{O}$ isotopic species in the atmosphere are ${ }^{14} \mathrm{~N}^{15} \mathrm{~N}^{16} \mathrm{O}(0.37 \%),{ }^{15} \mathrm{~N}^{14} \mathrm{~N}^{16} \mathrm{O}(0.37 \%)$ and ${ }^{14} \mathrm{~N}^{14} \mathrm{~N}^{16} \mathrm{O}$ (>99\%). Isotope abundances are usually reported in the $\delta$-notation (in per-mil; $\% 0), \delta^{15} \mathrm{~N}=\left[\left(\mathrm{R}_{\text {sample }} / \mathrm{R}_{\text {reference }}\right)-1\right] \times$ 1000 , where $R$ is the ratio of ${ }^{15} \mathrm{~N} /{ }^{14} \mathrm{~N}$ of a sample $\left(\mathrm{R}_{\text {sample }}\right)$ with respect to atmospheric $\mathrm{N}_{2}$ as the reference ( $\mathrm{R}_{\text {reference }}$ ) (Mariotti et al., 1981).

The intramolecular distribution of the nitrogen isotopes $\left({ }^{14} \mathrm{~N}^{15} \mathrm{NO}\right.$ vs. $\left.{ }^{15} \mathrm{~N}^{14} \mathrm{NO}\right)$ is termed SP and is expressed as the relative difference in $\delta^{15} \mathrm{~N}$ between $\alpha$ and $\beta$ position ( $\mathrm{SP}=\delta^{15} \mathrm{~N}^{\alpha}$ $\delta^{15} \mathrm{~N}^{\beta}$ ) (Toyoda and Yoshida, 1999). In analogy to the $\delta$-notation, the isotopomer analysis denotes the relative difference of the ${ }^{15} \mathrm{~N} /{ }^{14} \mathrm{~N}$ isotope ratio for a given position $\left(\delta^{15} \mathrm{~N} \alpha, \delta^{15} \mathrm{~N}^{\beta}\right)$ with respect to the standard $\left\{\right.$ e.g., $\delta^{15} \mathrm{~N}^{\alpha}=\left[\left({ }^{15} \mathrm{R}^{\alpha} /{ }^{15} \mathrm{R}_{\text {reference }}^{\alpha}\right)-1\right] \times$ 1000 , whereas ${ }^{15} \mathrm{R}^{\alpha}=\left({ }^{14} \mathrm{~N}^{15} \mathrm{~N}^{16} \mathrm{O}\right) /\left({ }^{14} \mathrm{~N}^{14} \mathrm{~N}^{16} \mathrm{O}\right)$ and ${ }^{15} \mathrm{R}_{\text {reference }}^{\alpha}$ is the isotope ratio of the standard material $\left(\mathrm{N}_{2} \mathrm{O}\right)$ (see below) (Toyoda and Yoshida, 1999). The SP has the advantage of being independent of the isotopic signature of the respective substrates (e.g., $\mathrm{NH}_{4}^{+}$or $\mathrm{NO}_{3}^{-}$) but of being specific for pathways (enzymes) 
involved in $\mathrm{N}_{2} \mathrm{O}$ formation (Toyoda et al., 2005; Sutka et al., 2006).

Microbial (enzymatic) processes usually lead to an isotopic fractionation due to different transformation rates of ${ }^{14} \mathrm{~N}$ and ${ }^{15} \mathrm{~N}$, resulting in isotopically lighter end-products than molecules in prior steps (Stein and Yung, 2003). Thus, the average ${ }^{15} \mathrm{~N} /{ }^{14} \mathrm{~N}$ ratio of $\mathrm{N}_{2} \mathrm{O}$, termed as $\delta^{15} \mathrm{~N}_{\mathrm{N} 2 \mathrm{O}}^{\text {bulk }}$, can be used to distinguish different production pathways in complex samples if the isotopic signature of the pure bacterial culture is known. However, the meaning of $\delta^{15} \mathrm{~N}_{\mathrm{N} 2 \mathrm{O}}^{\text {bulk }}$ can be limited since it is stronglydependent on the isotopic signature of the substrate, which usually is unknown, as well as on the physiological activity (Mariotti et al., 1981). Additionally, the isotopic composition of an intermediate (e.g., $\mathrm{N}_{2} \mathrm{O}$ during heterotrophic denitrification) is affected by production $\left(\mathrm{NO}_{3}^{-}\right.$reduction) as well as consumption $\left(\mathrm{N}_{2} \mathrm{O}\right.$ reduction) processes.

In addition to nitrogen isotopes, oxygen isotope ratios are also increasingly used in order to better distinguish between the $\mathrm{N}_{2} \mathrm{O}$ formation pathways (Yoshinari and Wahlen, 1985; Kool et al., 2007; Baggs, 2008; Frame and Casciotti, 2010). In this case $\delta^{18} \mathrm{O}$ denotes the relative difference in the ${ }^{18} \mathrm{O} /{ }^{16} \mathrm{O}$ ratio of $\mathrm{N}_{2} \mathrm{O}$ $\left(\mathrm{R}_{\text {sample }}\right)$ with respect to the reference $\left(\mathrm{R}_{\text {reference }}\right)$, in per-mil $(\% 0)$, usually being the Vienna Standard Mean Ocean Water (VSMOW) $\left\{\delta^{18} \mathrm{O}=\left[\left(\mathrm{R}_{\text {sample }} / \mathrm{R}_{\text {reference }}\right)-1\right] \times 1000\right\}$ (Wahlen and Yoshinari, 1985).

\section{ANALYSIS OF THE ISOTOPIC SIGNATURE OF $\mathrm{N}_{2} \mathrm{O}$}

There are basically two different analytical techniques available to analyze $\mathrm{N}_{2} \mathrm{O}$ nitrogen isotopic signatures at natural abundance levels (Table 2): (1) the isotope-ratio mass spectrometry (IRMS) (Brenninkmeijer and Röckmann, 1999; Toyoda and Yoshida, 1999), and (2) the recently developed QCLAS (Waechter et al., 2008).

\section{IRMS}

IRMS-based method is widely applied with an excellent precision and accuracy (Mohn et al., 2010). Nevertheless, the calibration procedure of the intramolecular nitrogen isotope distribution in $\mathrm{N}_{2} \mathrm{O}$ is still under debate. Originally, two alternative approaches have been proposed, one by Toyoda and Yoshida (1999) and one by Brenninkmeijer and Röckmann (1999), which resulted in a difference in SP of about $30 \%$ for tropospheric $\mathrm{N}_{2} \mathrm{O}$. The analysis of the SP by IRMS techniques relies on the $\mathrm{N}_{2} \mathrm{O}^{+}$and $\mathrm{NO}^{+}$fragment ions at the mass-to-charge ratio $(\mathrm{m} / \mathrm{z}) 44,45,46$ (for $\mathrm{N}_{2} \mathrm{O}$ ) and $m / z$ 30, 31 (for $\mathrm{NO}$ ). However, both calibration approaches do not take into account the isotope effects associated with the formation of $\mathrm{NO}^{+}$in the ion source of the mass spectrometer. Recently, Westley et al. (2007) investigated these discrepancies in more detail and found that these isotope effects have much smaller impact on the calibration procedure proposed by Toyoda and Yoshida (1999) (see below), and supported therefore this procedure as the most accurate basis for a community standard.

Furthermore, IRMS is a lab-based technique. Thus, the time resolution of $\mathrm{N}_{2} \mathrm{O}$ isotopic analysis during field measurement campaigns is therefore limited (Waechter et al., 2008). Nevertheless, in addition to nitrogen isotopes, the oxygen isotopic signature can also be analyzed routinely by IRMS.

\section{QCLAS}

QCLAS is a novel approach for site-specific analysis of nitrogen isotopes, with the advantage of a high sensitivity, time resolution, and portability, the latter of which enables field measurement campaigns (Waechter et al., 2008). This was demonstrated by Mohn et al. (2012), who recently presented first data of a high precision real-time analysis of site-specific isotopic signatures of atmospheric $\mathrm{N}_{2} \mathrm{O}$ above a grassland plot. The measurement campaign was run over 3 weeks with almost 550 analyzed gas samples. It was demonstrated that a continuous measurement of the $\mathrm{N}_{2} \mathrm{O}$ isotopic signature allowed improved detection of the dynamics of $\mathrm{N}_{2} \mathrm{O}$ production (before and after fertilizer application to the grassland plot), and thus opens a completely new field of applications. In another study, isotopic signature of $\mathrm{N}_{2} \mathrm{O}$, produced during batch-scale experiments with activated sludge, were analyzed in real time, which permitted to trace short-term fluctuations in SP and $\delta^{15} \mathrm{~N}_{\mathrm{N} 2 \mathrm{O}}^{\text {bulk }}$, allowing to identify $\mathrm{N}_{2} \mathrm{O}$ production pathways in biological wastewater treatment (Wunderlin et al., unpublished results).

The QCLAS is based on direct absorption laser spectroscopy in the mid-infrared range for simultaneous measurement of the most abundant $\mathrm{N}_{2} \mathrm{O}$ isotopic species, such as ${ }^{14} \mathrm{~N}^{15} \mathrm{~N}^{16} \mathrm{O}$, ${ }^{15} \mathrm{~N}^{14} \mathrm{~N}^{16} \mathrm{O}$, and ${ }^{14} \mathrm{~N}^{14} \mathrm{~N}^{16} \mathrm{O}$ (Waechter et al., 2008; Mohn

Table 2 | Advantages and disadvantages of isotope-ratio mass spectrometry (IRMS), quantum cascade laser absorption spectroscopy (QCLAS) and membrane-inlet mass spectrometry (MIMS) adapted from Baggs (2008).

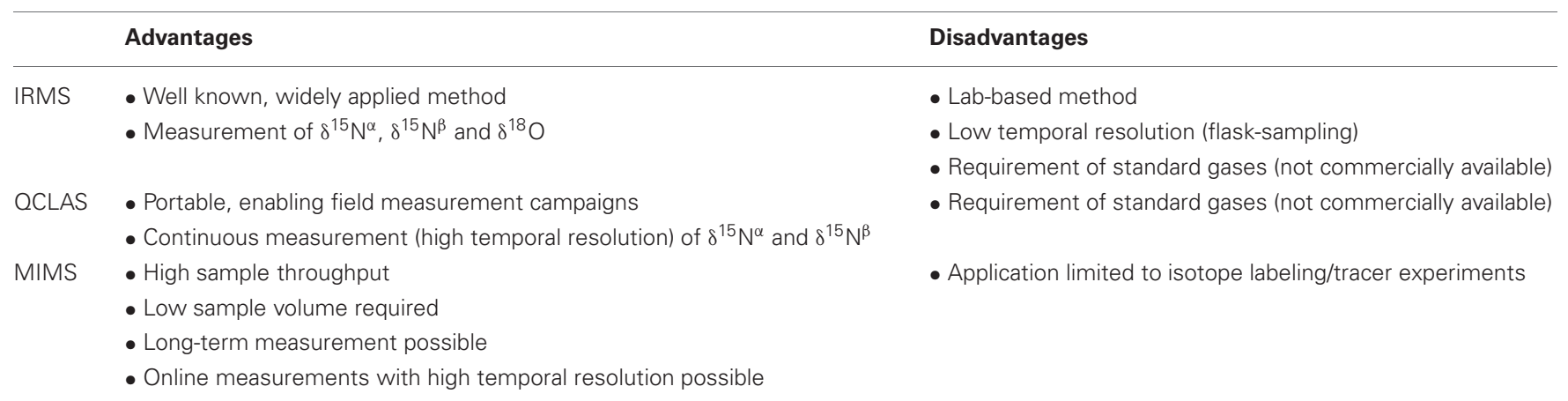


et al., 2010). In order to enable high precision analysis (e.g., a precision of $<0.1 \%$ for $\delta^{15} \mathrm{~N} \alpha$ and $\delta^{15} \mathrm{~N} \beta$ ) (Waechter et al., 2008) a combination with a pre-concentration unit is essential at ambient or sub-ambient mixing ratios (Mohn et al., 2010, 2012). For example, with the liquid nitrogen-free, fullyautomated pre-concentration unit built by Mohn et al. (2010), $\mathrm{N}_{2} \mathrm{O}$ can be concentrated by a factor of 200 (e.g., from ambient concentrations to around $60 \mathrm{ppm}$ ) from $10 \mathrm{~L}$ gas samples within $20 \mathrm{~min}$.

\section{CALIBRATION}

For both techniques, IRMS as well as QCLAS, an adequate calibration procedure needs to be applied, since instrumental nonlinearity and drifts impact the accuracy of the isotope ratio measurement (e.g., $\delta^{15} \mathrm{~N}_{\mathrm{N} 2 \mathrm{O}}^{\text {bulk }}$ values depend on the $\mathrm{N}_{2} \mathrm{O}$ gas concentration) (Waechter et al., 2008). However, international standards are not commercially available so far. Therefore, they need to be prepared and analyzed from other laboratories (intercalibration) for $\delta^{15} \mathrm{~N}_{\mathrm{N} 2 \mathrm{O}}^{\text {bulk }}, \delta^{15} \mathrm{~N}^{\alpha}$, and $\delta^{15} \mathrm{~N}^{\beta}$, to ensure that measurements are performed on a common scale and that results are comparable between laboratories (Westley et al., 2007). So far, the calibration procedure proposed by Toyoda and Yoshida (1999), as mentioned above, is accepted as the provisional basis for a community standard: $\mathrm{N}_{2} \mathrm{O}$ is synthesized via thermal decomposition of isotopically characterized $\mathrm{NH}_{4} \mathrm{NO}_{3}$, since it is known that the nitrogen atom at the center $(\alpha)$ position of $\mathrm{N}_{2} \mathrm{O}$ originates from $\mathrm{NO}_{3}^{-}$, while the end $(\beta)$ nitrogen comes from $\mathrm{NH}_{4}^{+}$. Using this calibration procedure a SP of tropospheric $\mathrm{N}_{2} \mathrm{O}$ of $18.7 \pm 2.2 \%$ is measured (Westley et al., 2007).

\section{MEMBRANE-INLET MASS SPECTROMETRY (MIMS)}

Membrane-inlet mass spectrometry (MIMS) was proposed as another promising tool to study the dynamics of $\mathrm{N}_{2} \mathrm{O}$ production in ${ }^{15} \mathrm{~N}$ labeling experiments. MIMS has a high sample throughput (within minutes), allows direct analysis of liquid or gas samples and requires only low sample amounts (Bauer, 1995; Baggs, 2008) (Table 2). Recently, it was coupled with an automated sampling and calibration unit (ASCU), and was tested in a long-term ${ }^{15} \mathrm{~N}$ $\mathrm{NO}_{3}^{-}$tracer experiment over 7 days. It was confirmed that ${ }^{15} \mathrm{~N}$ measurements of $\mathrm{N}_{2}$ and $\mathrm{N}_{2} \mathrm{O}$, detected as $\mathrm{N}_{2}$ at $m / z 28,29$, and $30\left(\mathrm{~N}_{2} \mathrm{O}\right.$ was reduced to $\mathrm{N}_{2}$ in an elemental copper furnace prior to analysis), are in good agreement with IRMS-based analysis (Eschenbach and Well, 2011).

The membrane-inlet part can also be combined with a quadrupole mass spectrometer for simultaneous online measurement of different $m / z$ ratios (e.g., ${ }^{15,15} \mathrm{~N}_{2} \mathrm{O}$ at $m / z=46,{ }^{14,15} \mathrm{~N}_{2} \mathrm{O}$ at $m / z=45,{ }^{15,15} \mathrm{~N}_{2}$ at $m / z=30,{ }^{14,15} \mathrm{~N}_{2}$ at $\left.m / z=29\right)$ with a time resolution of 1-2 min (Ettwig et al., 2010; Gao et al., 2010). Nevertheless, the interpretation of spectra corresponding to a certain gas mixture might be difficult since one peak can correspond to different atomic compositions (e.g., ${ }^{14,14} \mathrm{~N}_{2}^{+}$and $\mathrm{CO}^{+}$at $m / z=28$ ). This problem is reduced by applying ${ }^{15} \mathrm{~N}$ labeled substrates, where the only important remaining correction needed is for $m / z=30$, which consist of the signal from the ${ }^{15,15} \mathrm{~N}_{2}^{+}$fragment of ${ }^{15,15} \mathrm{~N}_{2} \mathrm{O}$, the ${ }^{14} \mathrm{NO}^{+}$fragment of ${ }^{14,14} \mathrm{~N}_{2} \mathrm{O}$ and ${ }^{15,15} \mathrm{~N}_{2}$ ) (Thomsen et al., 1994).

\section{ISOTOPIC SIGNATURE OF $\mathrm{N}_{\mathbf{2}}$ O: SITE PREFERENCE, $\delta^{15} \mathrm{~N}$ AND $\delta^{18} 0$ SITE PREFERENCE}

The SP is a promising tool for $\mathrm{N}_{2} \mathrm{O}$ source partitioning since it is specific to pathways involved and independent of the respective substrates (Sutka et al., 2006) (Table 3). For $\mathrm{N}_{2} \mathrm{O}$ production via $\mathrm{NH}_{2} \mathrm{OH}$ oxidation by typical $\mathrm{AOB}$ pure cultures values in the range of $30.8 \pm 5.9 \%$ to $35.6 \pm 1.4 \%$ were measured (Sutka et al., 2003, 2004, 2006) which is in agreement with recently reported SP values of marine AOA (30.8 $\pm 4.4 \%$ ) (Santoro et al., 2011). In contrast, Frame and Casciotti (2010) estimated $36.3 \pm$ $2.4 \%$ for a marine AOB. For nitrifier denitrification by AOB, the following SP values were reported: $0.1 \pm 1.7 \%$ (Sutka et al., 2006), $-0.8 \pm 5.8 \%$ (Sutka et al., 2003, 2004) and $-10.7 \pm$ $2.9 \%$ (Frame and Casciotti, 2010). For $\mathrm{N}_{2} \mathrm{O}$ production via heterotrophic denitrification SP values in the range of $-5.1 \%$ to $0 \%$ were reported (Toyoda et al., 2005; Sutka et al., 2006). Nitric oxide reductases (Nor) likely determine the $\mathrm{SP}$ of $\mathrm{N}_{2} \mathrm{O}$ during nitrifier denitrification as well as heterotrophic denitrification. The SP for both pathways is in the same range indicating that the involved Nor in AOB (cNor) and heterotrophic denitrifiers (cNor or qNor) (Stein and Yung, 2003; Stein, 2011) share a similar enzymatic mechanism. In case free $\mathrm{NO}$ is formed during $\mathrm{NH}_{2} \mathrm{OH}$ oxidation, any NO molecule that is funneled into nitrifier or heterotrophic denitrification (either directly or via initial oxidation to $\mathrm{NO}_{2}^{-}$) would result in $\mathrm{N}_{2} \mathrm{O}$ with an $\mathrm{SP}$ of $\sim 0 \%$ masking its initial $\mathrm{NH}_{2} \mathrm{OH}$ source.

The most probable explanation for a positive SP during $\mathrm{NH}_{2} \mathrm{OH}$ oxidation is a preferable ${ }^{14} \mathrm{~N}-{ }^{16} \mathrm{O}$ bond cleavage of a symmetric intermediate such as hyponitrite $\left({ }^{-16} \mathrm{O}^{14} \mathrm{~N}^{15} \mathrm{~N}^{16} \mathrm{O}^{-}\right)$, leading to an enrichment of ${ }^{14} \mathrm{~N}-{ }^{15} \mathrm{~N}-{ }^{16} \mathrm{O}$ (Schmidt et al., 2004a; Toyoda et al., 2005). In the current model of $\mathrm{N}_{2} \mathrm{O}$ formation from $\mathrm{NH}_{2} \mathrm{OH}$ oxidation, $\mathrm{NH}_{2} \mathrm{OH}$ is reduced to $\mathrm{NO}$, which is further reduced to $\mathrm{N}_{2} \mathrm{O}$ by an unidentified Nor. However, the positive $\mathrm{SP}$ of $\mathrm{N}_{2} \mathrm{O}$ formed from $\mathrm{NH}_{2} \mathrm{OH}$ oxidation can only be explained, (1) if the involved Nor has a different mechanism than Nor's mediating nitrifier and heterotrophic denitrification or (2) if $\mathrm{N}_{2} \mathrm{O}$ is formed by a different mechanism, which does not involve free NO. We suggest mechanisms involving $\mathrm{HNO}$ : either by formation of free $\mathrm{H}_{2} \mathrm{~N}_{2} \mathrm{O}_{2}$ with further chemical decomposition to $\mathrm{N}_{2} \mathrm{O}$ (discussed in section " $\mathrm{HNO}$ as intermediate of enzymatic $\mathrm{NH}_{2} \mathrm{OH}$ oxidation") or a site specific enzymatic cleavage of ${ }^{-} \mathrm{ONNO}^{-}$as discussed above (Schmidt et al., 2004a; Toyoda et al., 2005). Further insights in the enzymatic mechanism of HAO and potentially HAO-associated Nor with careful chemical control experiments are needed to elucidate the biochemical mechanism of $\mathrm{N}_{2} \mathrm{O}$ formation during $\mathrm{NH}_{2} \mathrm{OH}$ oxidation.

Furthermore, a positive SP is, in addition to $\mathrm{NH}_{2} \mathrm{OH}$ oxidation, also an indicator for increasing importance of $\mathrm{N}_{2} \mathrm{O}$ reductase activity relative to $\mathrm{N}_{2} \mathrm{O}$ production (substantially greater activity than $10 \%$ compared to production) (Yamagishi et al., 2007; Jinuntuya-Nortman et al., 2008; Koba et al., 2009). As a consequence, $\mathrm{N}_{2} \mathrm{O}$ reduction to $\mathrm{N}_{2}$ might lead to an overestimation of $\mathrm{N}_{2} \mathrm{O}$ production by $\mathrm{NH}_{2} \mathrm{OH}$ oxidation, or vice versa. Nevertheless, further investigations are necessary in order to determine the individual signatures under conditions more 
Table 3 | Advantages and disadvantages of SP, $\delta^{15} \mathrm{~N}^{\text {bulk }}$, and $\delta^{18} \mathrm{O}$, on a natural abundance or labeled level [adapted from Baggs (2008)].

\begin{tabular}{|c|c|c|}
\hline & Advantages & Disadvantages \\
\hline \multirow[t]{3}{*}{ Site preference (SP) } & - Independent of isotopic signature of substrates & - Unknown pathways might affect SP \\
\hline & - Noninvasive method & - SP from pure culture bacteria have to be known \\
\hline & - Specific for pathways involved & \\
\hline \multirow[t]{2}{*}{$\delta^{15} N^{\text {bulk }}$} & $\begin{array}{l}\text { - Characteristic fractionation of different pathways } \\
\text { (depending on the rate limiting step) }\end{array}$ & $\begin{array}{l}\text { - Depending on the isotopic signature of the substrate, as well as } \\
\text { the physiological activity }\end{array}$ \\
\hline & - Noninvasive method & - Multiple reaction steps (branching effects) cause uncertainty \\
\hline \multirow[t]{2}{*}{$\delta^{18} \mathrm{O}$} & - Noninvasive method & $\begin{array}{l}\text { - Oxygen exchange between } \mathrm{N} \text { species and } \mathrm{O}_{2} \text { or } \mathrm{H}_{2} \mathrm{O} \text { difficult to } \\
\text { quantify }\end{array}$ \\
\hline & - Additional information to nitrogen isotopic signature & \\
\hline \multirow[t]{2}{*}{$\begin{array}{l}\text { Isotope labeling of } \mathrm{N} \\
\text { and } \mathrm{O}\end{array}$} & $\begin{array}{l}\text { - Isotopically enriched substrates are not significantly } \\
\text { impacted by kinetic isotope fractionation }\end{array}$ & - The use of ${ }^{18} \mathrm{O}$ labeled $\mathrm{H}_{2} \mathrm{O}$ is not suitable under field conditions \\
\hline & - Quantification of individual pathways & - Isotopically labeled substances might impact microbial activity \\
\hline
\end{tabular}

representative for ecosystems with mixed culture populations (Wunderlin et al., unpublished results).

Under nitrifying conditions, $\mathrm{N}_{2} \mathrm{O}$ can theoretically be produced simultaneously via $\mathrm{NH}_{2} \mathrm{OH}$ oxidation as well as nitrifier denitrification. Thus, based on SP literature data, the individual contribution $\left(\mathrm{F}_{\mathrm{NN}}\right.$ : $\mathrm{NH}_{2} \mathrm{OH}$ oxidation; $\mathrm{F}_{\mathrm{ND}}$ : nitrifier denitrification) can be calculated from the following isotopomer mixing model:

$$
\mathrm{F}_{\mathrm{ND}}=\left(1-\mathrm{F}_{\mathrm{NN}}\right)=\frac{\left(\mathrm{SP}_{\mathrm{tot}}-\mathrm{SP}_{\mathrm{NN}}\right)}{\left(\mathrm{SP}_{\mathrm{ND}}-\mathrm{SP}_{\mathrm{NN}}\right)}
$$

where $\mathrm{SP}_{\mathrm{ND}}$ and $\mathrm{SP}_{\mathrm{NN}}$ are the end-member $\mathrm{SP}$ signatures of the $\mathrm{NH}_{2} \mathrm{OH}$ oxidation and nitrifier denitrification pathway, respectively, as reviewed above, and $\mathrm{SP}_{\text {tot }}$ the measured signature of the individual produced $\mathrm{N}_{2} \mathrm{O}$ (Frame and Casciotti, 2010).

\section{$\delta^{15} \mathrm{~N}$}

Wide ranges for $\delta^{15} \mathrm{~N}_{\mathrm{N} 2 \mathrm{O}}^{\text {bulk }}$ were reported so far, mainly due to limited information about the isotopic signature of the substrates or to both a huge complexity determined by multiple transformation processes involving different enzymes, as well as variable reaction rates or mechanisms affecting isotopic fractionation (Perez et al., 2006) (Table 3). For example, it was shown that isotopic fractionation during $\mathrm{NH}_{3}$ oxidation is variable, depending mainly on the amino acid sequences for the $\alpha$-subunit of AMO of the different investigated pure culture $\mathrm{AOB}$ (Casciotti et al., 2003). However, $\mathrm{N}_{2} \mathrm{O}$ produced by $\mathrm{AOB}$ during nitrifier denitrification or $\mathrm{NH}_{2} \mathrm{OH}$ oxidation is basically more strongly depleted in ${ }^{15} \mathrm{~N}\left(\Delta \delta^{15} \mathrm{~N}=\delta^{15} \mathrm{~N}_{\text {substrate }}-\delta^{15} \mathrm{~N}_{\mathrm{N} 2 \mathrm{O}}^{\text {bulk }}\right.$; in the range of between $40 \%$ and $68 \% 0$ ) compared to heterotrophic denitrification, where $\mathrm{N}_{2} \mathrm{O}$ is an obligate intermediate and the fractionation therefore depends on both production and consumption processes $\left(\Delta \delta^{15} \mathrm{~N}\right.$ of $0-39 \%$ ) (Yoshida, 1988; Yoshida et al., 1989; Stein and Yung, 2003; Perez et al., 2006; Koba et al., 2009; Park et al., 2011).

\section{$\delta^{18} 0$}

The oxygen isotopic signature of $\mathrm{N}_{2} \mathrm{O}\left(\delta^{18} \mathrm{O}\right)$ is also used as a tool for $\mathrm{N}_{2} \mathrm{O}$ source partitioning, even though this approach faces a couple of difficulties: for example, $\mathrm{N}_{2} \mathrm{O}$ production via $\mathrm{NH}_{2} \mathrm{OH}$ oxidation as well heterotrophic $\mathrm{N}_{2} \mathrm{O}$ reduction result in a positive correlation between the $\delta^{18} \mathrm{O}$ in $\mathrm{N}_{2} \mathrm{O}$ and SP (Frame and Casciotti, 2010) (Table 3). Furthermore, $\delta^{18} \mathrm{O}$ enrichment factors are scarce and highly variable (Park et al., 2011), and are reported to be strongly influenced by oxygen exchange or incorporation, such as (1) oxygen incorporation (from dissolved $\mathrm{O}_{2}$ ) into $\mathrm{NH}_{2} \mathrm{OH}$ during the oxidation of $\mathrm{NH}_{4}^{+}$to $\mathrm{NH}_{2} \mathrm{OH}$, (2) oxygen incorporation (from $\mathrm{H}_{2} \mathrm{O}$ ) into $\mathrm{NO}_{2}^{-}$during the oxidation of $\mathrm{NH}_{2} \mathrm{OH}$ to $\mathrm{NO}_{2}^{-}$, and (3) oxygen exchange between $\mathrm{NO}_{2}^{-} / \mathrm{NO}_{3}^{-}$ and $\mathrm{H}_{2} \mathrm{O}$ (Kool et al., 2007). For example, it was shown that $64-94 \%$ of the oxygen atoms in the precursors of $\mathrm{N}_{2} \mathrm{O}$ were exchanged with oxygen atoms in $\mathrm{H}_{2} \mathrm{O}$ (Snider et al., 2009; Park et al., 2011), which underscores the fact that the understanding and quantification of the effect of oxygen exchange between $\mathrm{H}_{2} \mathrm{O}$ and dissolved nitrogen species is and will remain challenging. Isotopic labeling is a promising approach to overcome such difficulties (see below), but up to now the natural abundance oxygen isotopic signature should be used with caution in $\mathrm{N}_{2} \mathrm{O}$ source partitioning studies (Kool et al., 2007, 2010).

\section{N AND 0 LABELING}

Beside natural abundances, nitrogen and oxygen isotope labeling techniques have been applied to study and quantify $\mathrm{N}_{2} \mathrm{O}$ production pathways (Table 3). For example, Poth and Focht (1985) investigated the relative importance of the $\mathrm{NH}_{2} \mathrm{OH}$ oxidation and nitrifier denitrification pathway in Nitrosomonas europaea pure culture by applying ${ }^{14} \mathrm{~N}-\mathrm{NH}_{4}^{+}$in combination with ${ }^{15} \mathrm{~N}-\mathrm{NO}_{2}^{-}$. Based on the large amounts of double-labeled ${ }^{15,15} \mathrm{~N}_{2} \mathrm{O}(\mathrm{m} / z=$ 46), it was concluded that nitrifier denitrification is the dominant pathway. Baggs and Blum (2004) determined the relative contribution of nitrification and denitrification to ${ }^{15} \mathrm{~N}-\mathrm{N}_{2} \mathrm{O}$ production by the application of ${ }^{14} \mathrm{NH}_{4}{ }^{15} \mathrm{NO}_{3}$ and ${ }^{15} \mathrm{NH}_{4}{ }^{15} \mathrm{NO}_{3}$. However, such conventional ${ }^{15} \mathrm{~N}$ labeling techniques do not allow to distinguish between $\mathrm{NH}_{2} \mathrm{OH}$ oxidation and nitrifier denitrification in mixed population systems (Kool et al., 2010). As a consequence, a dual isotope approach was applied, based on ${ }^{18} \mathrm{O}$ labeling of $\mathrm{H}_{2} \mathrm{O}$ as well as ${ }^{15} \mathrm{~N}$-labeling of $\mathrm{NH}_{4}^{+}$or $\mathrm{NO}_{3}^{-}$(Wrage et al., 2005). The basic concept behind is, that AOB use oxygen from $\mathrm{O}_{2}$ for the oxidation of $\mathrm{NH}_{4}^{+}$to $\mathrm{NH}_{2} \mathrm{OH}$, but oxygen from $\mathrm{H}_{2} \mathrm{O}$ for the oxidation of $\mathrm{NH}_{2} \mathrm{OH}$ to $\mathrm{NO}_{2}^{-}$(see above). As 
such, the ${ }^{18} \mathrm{O}$ signature of $\mathrm{N}_{2} \mathrm{O}$ produced via nitrifier denitrification reflect to $50 \%$ the signature of $\mathrm{O}_{2}$ and to the other $50 \%$ the signature of $\mathrm{H}_{2} \mathrm{O}$, which is in this study artificially enriched in ${ }^{18} \mathrm{O}$ (Kool et al., 2007), under the assumption that no further oxygen is exchanged between $\mathrm{NO}_{2}^{-}$and $\mathrm{H}_{2} \mathrm{O}$. In contrast, the ${ }^{18} \mathrm{O}$ signature of $\mathrm{N}_{2} \mathrm{O}$ derived from $\mathrm{NH}_{2} \mathrm{OH}$ oxidation reflects to $100 \%$ the signature of $\mathrm{O}_{2}$ (Wrage et al., 2005; Kool et al., 2010). Nevertheless, the effect of oxygen exchange has to be taken into account.

\section{NATURAL SAMPLES}

The analysis of the natural abundance isotopic signature of $\mathrm{N}_{2} \mathrm{O}$ emitted from ecosystems such as soils, rivers or biological wastewater treatment indicate that $\mathrm{N}_{2} \mathrm{O}$ from terrestrial and aquatic sources is depleted in ${ }^{15} \mathrm{~N}$ compared to tropospheric $\mathrm{N}_{2} \mathrm{O}\left(\delta^{15} \mathrm{~N}=7 \%\right.$ and $\delta^{18} \mathrm{O}=20.7 \%$ ) (Stein and Yung, 2003), but also show a huge variability and complexity, making process identification ambiguous at large scale. For example, in biological wastewater treatment an average $\delta^{15} \mathrm{~N}_{\mathrm{N} 2 \mathrm{O}}^{\text {bulk }}$ of $-9.6 \%$, SP of $16 \%$ and $\delta^{18} \mathrm{O}$ of $22-44.3 \%$ were estimated (Yoshinari and Wahlen, 1985; Toyoda et al., 2011), indicating that nitrification as well as denitrification contributed to $\mathrm{N}_{2} \mathrm{O}$ production. $\mathrm{N}_{2} \mathrm{O}$ emitted from agricultural soils is reported to be strongly depleted in $\delta^{15} \mathrm{~N}_{\mathrm{N} 2 \mathrm{O}}^{\text {bulk }}$ (e.g., - $34 \%$ ) (Park et al., 2011), referring to nitrification dominated $\mathrm{N}_{2} \mathrm{O}$ production. Isotopic signatures of $\mathrm{N}_{2} \mathrm{O}$ emitted from rivers and streams are in the range of $-18 \%$ to $2.4 \%$ ( $\left({ }^{15} \mathrm{~N}^{\text {bulk }}\right),-6 \%$ to $31 \%$ (SP) and $17 \%$ to $53 \% 0\left(\delta^{18} \mathrm{O}\right)$ being in line with values reported above, which indicates to be highly influenced by sources such as agriculture or municipal wastewater treatment (Toyoda et al., 2009; Baulch et al., 2011). This is underscored by a recent study that investigates the oxygen and intramolecular nitrogen isotopic composition of $\mathrm{N}_{2} \mathrm{O}$, confirming that nitrogen-based fertilizer application was largely responsible for the rise in $\mathrm{N}_{2} \mathrm{O}$ atmospheric concentration during the last 65 years (Park et al., 2012).

\section{OUTLOOK}

In this section, the isotopic signature of $\mathrm{N}_{2} \mathrm{O}$, especially the $\mathrm{SP}$, is discussed to be a powerful tool to distinguish $\mathrm{N}_{2} \mathrm{O}$ production pathways. Recent technological advances, e.g., the development and application of the QCLAS, now allow a high temporal resolution in the analysis of the isotopic changes of $\mathrm{N}_{2} \mathrm{O}$. Nevertheless, an adequate calibration procedure still needs to be applied, since instrumental nonlinearity and drifts impact the accuracy of the isotope ratio measurement, and calibration standards are not commercially available so far. It is a pressing issue to further investigate the characteristic isotopic signatures of the individual $\mathrm{N}_{2} \mathrm{O}$ production pathways in mixed microbial communities under controlled conditions, in order to more accurately interpret isotopic signatures from complex environmental systems. Further, it is important to study $\mathrm{N}_{2} \mathrm{O}$ isotopic signatures with respect to involved microbial communities, enzymatic reaction mechanisms and enzymatic transformation rates. The use of the oxygen isotopic signature of $\mathrm{N}_{2} \mathrm{O}$ as a reliable tool for pathway identification requires the elucidation of mechanisms and rates of oxygen exchange in the future.

\section{MOLECULAR APPROACHES TO UNDERSTANDING MICROBIAL NO AND N 20 FORMATION}

While abiotic variables such as dissolved $\mathrm{O}_{2}, \mathrm{pH}, \mathrm{NO}_{2}^{-}$, and other nitrogen compounds have long been recognized to exert a strong influence on rates of microbial $\mathrm{NO}$ and $\mathrm{N}_{2} \mathrm{O}$ emissions, the importance of microbial community composition and dynamics to such emissions is still little understood (Wallenstein et al., 2006). As such, researchers have recently begun supplementing process-level $\mathrm{NO}$ and $\mathrm{N}_{2} \mathrm{O}$ emission measurements in a variety of environments with molecular techniques aimed at characterizing abundance, diversity, community structure, and activity of microbial guilds involved in nitrogen cycling. Here, we briefly introduce emerging molecular approaches to the delineation of key pathways, communities, and controls of $\mathrm{NO}$ and $\mathrm{N}_{2} \mathrm{O}$ production, and we summarize recent applications of these tools.

\section{QUANTIFYING THE GENETIC POTENTIAL FOR $\mathbf{N}_{2} \mathbf{O}$ CONSUMPTION}

An appealing focus for application of molecular tools in environmental samples is direct quantification via the quantitative polymerase chain reaction (qPCR) of relevant functional genes (Smith and Osborn, 2008). Such an approach most commonly targets DNA, not RNA, and is thus a measure of genetic potential in the environment and not the activity.

Owing to the relative independence of each catabolic step, denitrification has been described as having a modular organization (Zumft, 1997). Indeed, Jones et al. (2008) concluded based on an analysis of 68 sequenced genomes of heterotrophic denitrifiers that approximately $1 / 3$ lacked the nos $Z$ gene encoding for $\mathrm{N}_{2} \mathrm{O}$ reductase and thus lack the genetic capacity for $\mathrm{N}_{2} \mathrm{O}$ reduction. Based on this assessment, researchers have hypothesized that the ratio of nos $Z$ to the sum of nirK and nirS encoding for copper and cytochrome $\mathrm{cd}_{1}$-type nitrite reductases, respectively, is representative of the fraction of denitrifiers in a given environment that generate $\mathrm{N}_{2} \mathrm{O}$ as a catabolic end product. Environments with high nos $Z /(n i r K+$ nirS $)$ ratios are likely associated with a high capacity for $\mathrm{N}_{2} \mathrm{O}$ consumption, and thus for low $\mathrm{N}_{2} \mathrm{O}$ emissions. Commonly used primers and qPCR conditions for genes relevant for $\mathrm{NO}$ and $\mathrm{N}_{2} \mathrm{O}$ turnover during $\mathrm{N}$-cycling are available in the literature and are listed in Table 4, and thus the measurement of such ratios are feasible with little method development. Application of such tools has commonly shown a lower abundance of nos $Z$ compared to other denitrifying reductases, particularly in soil environments (Henry et al., 2006; Hallin et al., 2009; Bru et al., 2011).

First assessments of this hypothesis are somewhat conflicting. In favor for the hypothesis, Philippot et al. (2009) demonstrated a negative correlation between nos $Z$ proportional abundance and $\mathrm{N}_{2} \mathrm{O} /\left(\mathrm{N}_{2}+\mathrm{N}_{2} \mathrm{O}\right)$ ratio in grassland pasture soil. In a followup study, Philippot et al. (2011) dosed three soils with several dilutions of a denitrifying bacterial isolate known to lack the $n o s Z$ gene, and measured the response at the DNA level of nirK, nirS, and nos $Z$ genes via $\mathrm{qPCR} . \mathrm{N}_{2} \mathrm{O}$ emissions increased in all soils upon dosing of the nos $Z$-deficient isolate. However, in two of the three soils, the increase in denitrification potential (relative to non-inoculated controls) was higher than the measured increase in $\mathrm{N}_{2} \mathrm{O}$ emissions, suggesting that the original denitrifier community was capable of acting as a sink for 
Table 4 | Reported primers and literature references relevant for $\mathrm{NO}$ and $\mathrm{N}_{2} \mathrm{O}$ turnover during $\mathrm{N}$-cycling.

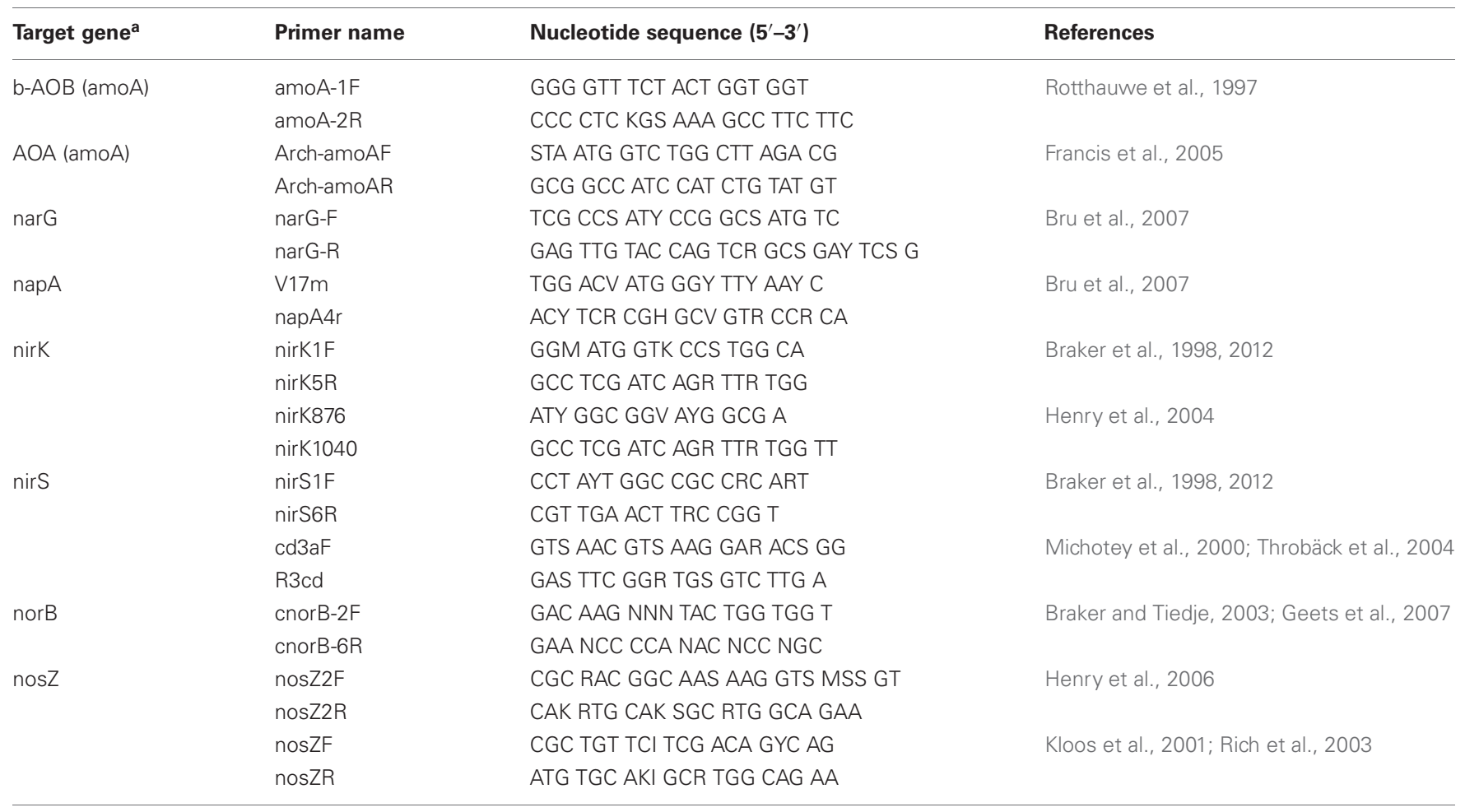

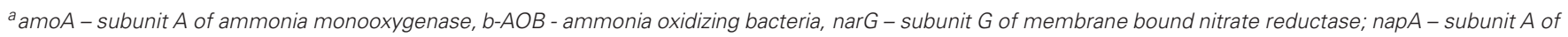

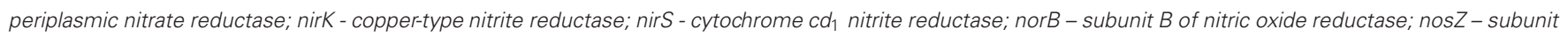
$Z$ of nitrous oxide reductase.

$\mathrm{N}_{2} \mathrm{O}$ production. Moreover, ratios of $\mathrm{N}_{2} \mathrm{O}$ emissions to total denitrifying end products $\left(\mathrm{N}_{2} \mathrm{O}+\mathrm{N}_{2}\right)$ in non-inoculated soils were not correlated to nos $Z /(n i r K+n i r S)$. While the authors acknowledge that abundance of nos $Z$ deficient denitrifiers may not be as important in soils with a high $\mathrm{N}_{2} \mathrm{O}$ uptake capacity, their results clearly demonstrate that abundance of denitrifiers incapable of $\mathrm{N}_{2} \mathrm{O}$ reduction can influence denitrification end products in natural environments. Similarly, Morales et al. (2010) document a strong positive correlation between the difference in nirS and nosZ gene abundance (nirS-nosZ; nirK was not quantified) and $\mathrm{N}_{2} \mathrm{O}$ emissions in 10 soils. Garcia-Lledo et al. (2011) suggested that a significant decrease in nos $Z$ gene abundance during periods of high $\mathrm{NO}_{3}^{-}$content in a constructed wetland might be indicative of increased genetic capacity for (unmeasured) $\mathrm{N}_{2} \mathrm{O}$ emissions.

In contrast, Čuhel et al. (2010) detail a significant but, puzzlingly, positive correlation in grassland soil between nos $\mathrm{Z} /($ nirS + nirK $)$ ratios and $\mathrm{N}_{2} \mathrm{O} /\left(\mathrm{N}_{2}+\mathrm{N}_{2} \mathrm{O}\right)$, but caution that the relative importance of denitrifier community composition and enzyme regulation relative to proportion of nos $Z$ deficient community members remains uncertain. In line with this result, Braker and Conrad (2011) found similar ratios of nosZ/(nirS + nirK) via Most Probable Number (MPN-) PCR in three soils with profoundly different $\mathrm{N}_{2} \mathrm{O} /\left(\mathrm{N}_{2}+\mathrm{N}_{2} \mathrm{O}\right)$ ratios, and concluded that the hypothesis that a higher abundance of denitrifiers lacking nos $Z$ is linked to increased $\mathrm{N}_{2} \mathrm{O}$ emissions may be an oversimplification.
The genetic potential for $\mathrm{N}_{2} \mathrm{O}$ production via nitrifier denitrification in $\mathrm{AOB}$ (and possibly AOA) could theoretically be measured via qPCR of the nirK and norB genes. Design of such analyses is hampered due to the fact that AOB nirK and norB genes are not phylogenetically distinct from that of heterotrophic denitrifying organisms (Cantera and Stein, 2007; Garbeva et al., 2007). In addition, NorB is not the only $\mathrm{NO}$ reductase in $\mathrm{AOB}$ (Stein, 2011).

\section{COMMUNITY STRUCTURE AND DIVERSITY IMPACTS ON NO AND $\mathrm{N}_{\mathbf{2}} \mathrm{O}$ PRODUCTION}

In addition to monitoring abundance of nos $Z$ deficient denitrifiers, PCR-based tools are now being applied to the investigation of links between community structure and $\mathrm{N}_{2} \mathrm{O}$ emissions for both nitrifiers and denitrifiers. For this purpose, community structure is commonly profiled via cultivation-independent molecular fingerprinting methods, such as terminal restriction fragment length polymorphism (T-RFLP) or denaturing gradient gel electrophoresis (DGGE), targeting either 16S rRNA fragments specific to the functional guild of interest or functional genes (for example, nirK or $a m o A$ ) directly. In addition, traditional cloning and Sanger sequencing and, increasingly, barcoded amplicon-based pyrosequencing of functional genes are often employed for robust phylogenetic comparisons. Readers are referred to Prosser et al. (2010) for a detailed methodological description of these and other nucleic-acid based methods. Multivariate statistical analyses such as canonical correspondence 
analysis (CCA), redundancy analysis (RDA) (Ramette, 2007; Wells et al., 2009), or path analysis (Avrahami and Bohannan, 2009) can then be used to explore the interplay between abiotic variables, community composition, and extant process rates.

It should be emphasized that the molecular and statistical tools highlighted above are most commonly used in microbial ecology to explore correlations, rather than causal associations, between community structure and function in complex microbial communities. As discussed in detail by Reed and Martiny (2007) directly testing causal relationships between microbial community composition or diversity and ecosystem processes is significantly more difficult, but experimental approaches often drawn from classical ecology are now being adapted to this challenge. We anticipate that future studies testing the functional significance of microbial community structure to $\mathrm{NO}$ or $\mathrm{N}_{2} \mathrm{O}$ production will benefit greatly from these approaches.

Studies targeting the relationship between nitrifier community composition and greenhouse gas production are sparse at present, despite the fact that ample molecular tools are available for this purpose. Avrahami and Bohannan (2009) employed a combination of qPCR and T-RFLP to explore the response of $\mathrm{N}_{2} \mathrm{O}$ emission rates and betaproteobacterial $\mathrm{AOB}$ abundance and composition in a California meadow to manipulations in temperature, soil moisture, and fertilizer concentration. While a complex interaction between factors was determined to directly and indirectly contribute to $\mathrm{N}_{2} \mathrm{O}$ emission rates, path analysis suggested that the major path by which $\mathrm{NH}_{4}^{+}$influenced emission rates in the high $\mathrm{N}$ fertilization treatment was indirectly via two specific AOB clusters. This observation suggested a significant relationship between $\mathrm{AOB}$ community structure and $\mathrm{N}_{2} \mathrm{O}$ emission rates. It is important to note that this study did not attempt to discriminate between the nitrifier denitrification and $\mathrm{NH}_{2} \mathrm{OH}$ oxidation pathways for AOB-linked $\mathrm{N}_{2} \mathrm{O}$ production, nor was the relative importance of heterotrophic denitrification vs. nitrification for overall $\mathrm{N}_{2} \mathrm{O}$ emissions directly compared.

Assessment of the importance of DNRA as a process, and diversity therein, to $\mathrm{NO}$ and $\mathrm{N}_{2} \mathrm{O}$ production is in its infancy. It has been suggested that our understanding of this little understood phenomena would benefit from the future investigations employing molecular techniques to quantify abundance and diversity of the $n r f$ gene in conjunction with either modeling or stable isotope-based methods (Baggs, 2011). To our knowledge, such an assessment has yet to be conducted.

The relationship between denitrifier community composition and $\mathrm{N}_{2} \mathrm{O}$ emissions, while still ambiguous, has been studied in more detail. Palmer et al. (2010) investigated narG (encoding for membrane-bound nitrate reductase, Nar) and nos Z phylogenetic diversity in a low-pH fen via gene clone libraries and T-RFLP. They documented novel narG and nos $Z$ genotypes and a phylogenetically diverse low-pH adapted denitrifier community, and suggested that the novel community structure may be responsible for complete denitrification and low $\mathrm{N}_{2} \mathrm{O}$ emissions under in situ conditions. In a more recent study, Palmer et al. (2012) investigated denitrifier gene diversity in peat circles in the arctic tundra via barcoded amplicon pyrosequencing of narG, nirK/nirS, and nosZ, and found evidence that high and low $\mathrm{N}_{2} \mathrm{O}$ emission patterns were associated with contrasting denitrifier community composition. Braker et al. (2012) found that, of three soils profiled, the soil with the most robust denitrification (lowest $\mathrm{N}_{2} \mathrm{O} / \mathrm{N}_{2}$ ratio) harbored the most diverse denitrifier community, as measured via nos $Z$ and nirK sequence diversity, suggesting that differences in community composition (higher diversity) are associated with ecosystem-level functional differences. In denitrifying bioreactors, population dynamics tracked via $16 \mathrm{~S}$ rRNA-based T-RFLP were strongly correlated to $\mathrm{NO}_{2}^{-}$ appearance and emissions of $\mathrm{N}_{2} \mathrm{O}$ (Gentile et al., 2007). In contrast, Rich and Myrold (2004) found little relationship between nos $Z$ phylogenetic diversity as measured via T-RFLP in wet soils and creek sediments in an agrosystem, and suggested that activity and community composition were uncoupled in this ecosystem.

Taken together, the body of literature reviewed here suggests that, in at least some cases, community structure and diversity can play a functionally significant role in microbial $\mathrm{N}_{2} \mathrm{O}$ emissions. The importance of community composition relative to environmental parameters and metabolic adaptation in response to transient conditions (for example, shifts in patterns of gene expression or regulation) in determining $\mathrm{N}_{2} \mathrm{O}$ production, however, remains poorly understood. A worthwhile, but challenging future research direction would be to tease apart the influence of whole community metabolic adaptation versus community shifts on $\mathrm{NO} / \mathrm{N}_{2} \mathrm{O}$ emissions in mixed microbial communities.

\section{A ROLE FOR VARIATION IN REGULATORY RESPONSE}

Differences in transcriptional and translational regulation as well as enzyme activity have also been highlighted as potentially critical modulators of microbial $\mathrm{NO}$ or $\mathrm{N}_{2} \mathrm{O}$ production (Richardson et al., 2009; Bergaust et al., 2011; Braker and Conrad, 2011). Such differences likely contribute to observed associations between community structure and greenhouse gas production discussed above. Strong regulation at the transcriptional, translational, and enzyme level is likely occurring in both nitrifier and denitrifier communities, and such regulation complicates attempts to directly relate abundance or diversity of functional guilds to process rates (Braker and Conrad, 2011). Similarly, transient nearinstantaneous $\mathrm{NO}$ and $\mathrm{N}_{2} \mathrm{O}$ accumulation in active nitrifying and denitrifying biofilms in response to $\mathrm{O}_{2}$ or $\mathrm{NO}_{2}^{-}$perturbations, as measured with high temporal resolution via microelectrodes, strongly suggests that dynamics are controlled in some cases at the enzyme level (Schreiber et al., 2009). Indeed, culture-based assays targeting denitrifier isolates from two soils demonstrated substantial diversity in sensitivity of Nos enzymes to $\mathrm{O}_{2}$ and provided a physiological underpinning for a previously observed link between denitrifier community composition and rate of $\mathrm{N}_{2} \mathrm{O}$ production (Cavigelli and Robertson, 2000).

Gene expression can be readily quantified with reverse transcriptase quantitative PCR (RT-qPCR), and researchers are now beginning to explore the relationship between gene expression patterns for critical functional genes (amoA, hao, nirK, nirS, norB, and nosZ) and $\mathrm{NO} / \mathrm{N}_{2} \mathrm{O}$ emissions. Yu et al. (2010) used such an approach to quantify expression of amoA, hao, nirK, and norB in chemostats of Nitrosomonas europaea during initiation and recovery from transient anoxic conditions. Surprisingly, expression profiles of nirK and norB were not strongly linked; strong 
overexpression of nirK concomitant with $\mathrm{NO}$ accumulation was observed upon initiation of anoxia, and at the same time nor $B$, amoA, and hao gene transcripts declined in abundance. $\mathrm{N}_{2} \mathrm{O}$ emissions peaked during recovery to aerated conditions, but did not correlate strongly to gene expression. The methods of $\mathrm{Yu}$ et al. (2010) provide a robust road map for examining relationships between nitrifier gene expression and $\mathrm{NO} / \mathrm{N}_{2} \mathrm{O}$ emissions in mixed communities in environmental settings, though it should be noted that such an analysis is complicated by the polyphyletic nature of the AOB nirK and norB genes.

RT-qPCR has also been used to assess the relationship between gene expression and $\mathrm{NO} / \mathrm{N}_{2} \mathrm{O}$ production in systems dominated by denitrifiers. Liu et al. (2010) quantified the relationship between nirS, nirK, and nos $Z$ gene pools, their transcription products, and gas kinetics $\left(\mathrm{NO}, \mathrm{N}_{2} \mathrm{O}\right.$, and $\mathrm{N}_{2}$ ) as a function of $\mathrm{pH}$ in soils. Interestingly, neither gene pool abundance, nor transcription rates could explain a profound increase in $\mathrm{N}_{2} \mathrm{O}$ emissions at low $\mathrm{pH}$. The authors attribute the observed $\mathrm{N}_{2} \mathrm{O}: \mathrm{N}_{2}$ product ratio to post-transcriptional phenomenon, although it is also plausible that enhanced chemo-denitrification may play a role.

A worthy future contribution could be made via direct environmental metatranscriptomic assessment of patterns in microbial gene expression in environments with different or varying rates of $\mathrm{NO}$ or $\mathrm{N}_{2} \mathrm{O}$ production. Metatranscriptomics is the direct sequencing of cDNA generated via reverse transcription of environmental RNA transcripts, and therefore provides a picture of currently transcribed genes in a given environment (Morales and Holben, 2011). In line with the results of Liu et al. (2010), it is important to recognize that measurement of the size or diversity of the gene transcript pool neglects post-transcriptional regulation governing, for example, the assembly of $\mathrm{N}_{2} \mathrm{O}$ reductase and enzyme activity (Braker and Conrad, 2011). As of yet, variations in post-transcriptional regulation at the community level and its effect on $\mathrm{NO} / \mathrm{N}_{2} \mathrm{O}$ production has been little explored in nitrifying and denitrifying pure cultures and communities. Critical insights in this regard may be possible in the future from an approach coupling metatranscriptomics and metaproteomicsthat is, direct measurement of the composition of the proteome in an environment.

\section{A NEED FOR AN INTEGRATED APPROACH TO NO AND $\mathrm{N}_{2} \mathrm{O}$ TURNOVER IN COMPLEX MICROBIAL COMMUNITIES}

$\mathrm{NO}$ and $\mathrm{N}_{2} \mathrm{O}$ can be produced by many different biological and chemical reactions. Considerable progress has been made to allocate $\mathrm{NO}$ and $\mathrm{N}_{2} \mathrm{O}$ production to certain biological pathways, but commonly some uncertainty remains, because many processes share the same reaction sequence for $\mathrm{N}_{2} \mathrm{O}$ production via $\mathrm{NO}$ and $\mathrm{NO}_{2}^{-}$. We delineated basically three-independent approaches to allocate pathways (indirect inference; isotopic signature of $\mathrm{N}_{2} \mathrm{O}$, and isotopic labeling). Parallel use of these approaches will increase confidence in the interpretation. The possibility for various chemical reaction that produce and consume $\mathrm{NO}$ and $\mathrm{N}_{2} \mathrm{O}$ additionally complicate the picture. Chemical reactions can be important in engineered systems that employ waters with concentrated $\mathrm{N}$-contents and in natural systems, where low $\mathrm{pH}$ values coincide with high ammonia inputs. However, in most natural systems and in municipal wastewater treatment, chemical reactions will probably not be the main contributors of $\mathrm{NO}$ and $\mathrm{N}_{2} \mathrm{O}$ emissions. Nevertheless, the possibility of chemical $\mathrm{NO}$ and $\mathrm{N}_{2} \mathrm{O}$ production has to be considered when interpreting measurements results. Experiments with inactivated biomass could help to give a first estimation of the chemical production rates. However, care has to be taken since the chemical conditions that facilitate chemical $\mathrm{NO}$ and $\mathrm{N}_{2} \mathrm{O}$ production such as $\mathrm{pH}$ and trace metal availability are in turn shaped by microbial activity.

Molecular methods have largely been applied independently from the stable isotope and microelectrode approaches. Ample opportunities exist for integration of these techniques. Indeed, it is clear that such an integrated approach is critical to assessing the importance of microscale heterogeneity in environmental parameters, microbial community structure and stability, and genetic regulation to observed process-level $\mathrm{N}_{2} \mathrm{O}$ emission rates.

Joint use of stable isotope methods in conjunction with molecular techniques appears particularly important, given reported difference in isotope effects depending on the community structure of nitrifiers (Casciotti et al., 2003) or denitrifiers (Toyoda et al., 2005) present. In addition, linking source-partitioned $\mathrm{N}_{2} \mathrm{O}$ as measured via stable isotope techniques to the underlying microbial communities via molecular approaches may allow a more significant measure of the strength of coupling between microbial diversity and measured emissions (Baggs, 2008, 2011). One promising way forward is to assess environmental conditions that favor a shift of dominant $\mathrm{N}_{2} \mathrm{O}$ production pathway (for example, from denitrification to nitrification, or vice versa) as measured via stable isotope methods, and to simultaneously link such a shift to diversity and abundance of functional gene pools and transcripts via PCR-based molecular approaches. Such an approach has the potential to yield insights into the relative importance of dominant functional guilds, community composition, and activity in determining microbial $\mathrm{NO} / \mathrm{N}_{2} \mathrm{O}$ production rates. A fruitful first application would be to combine stable isotope-based methods with the molecular approach pioneered by $\mathrm{Yu}$ et al. (2010) for delineating the relationship between transcriptional response of the model AOB Nitrosomonas europaea and $\mathrm{NO} / \mathrm{N}_{2} \mathrm{O}$ production. This coupled approach would allow conclusive verification of conditions proposed by Chandran et al. (2011) to favor a switch between nitrifier denitrification and $\mathrm{NH}_{2} \mathrm{OH}$ oxidation as dominant sources $\mathrm{NO}$ and $\mathrm{N}_{2} \mathrm{O}$ production.

Similarly, it is clear that molecular tools and microelectrodes are complementary to study $\mathrm{NO}$ and $\mathrm{N}_{2} \mathrm{O}$ turnover. An excellent example of such integration is provided by Okabe et al. (2011), who profiled microscale gradients in $\mathrm{N}_{2} \mathrm{O}$ emissions in anammox granules and compared these profiles to spatial location of $\mathrm{AOB}$, as measured via fluorescence in situ hybridization (FISH). Based on their results, the authors concluded that putative heterotrophic denitrifiers in the inner part of the granule, not $\mathrm{AOB}$, were likely responsible for the majority of the extant $\mathrm{N}_{2} \mathrm{O}$ process emissions. A similar approach is likely applicable in a wide variety of environments, including flocs, sediments, soils, and microbial mats. In addition, use of either FISH probes with higher phylogenetic resolution or depth stratified DNA/RNA extraction coupled to PCR-based measurements may allow a direct microscale assessment of links between microbial diversity 
and activity and $\mathrm{NO} / \mathrm{N}_{2} \mathrm{O}$ production profiles. Such a microscale assessment is important because stratified environments likely contain both regions of $\mathrm{N}_{2} \mathrm{O}$ production and consumption that are masked during bulk $\mathrm{NO} / \mathrm{N}_{2} \mathrm{O}$ concentration measurements or DNA/RNA extractions. In addition, microelectrode measurements with high temporal resolution should be combined with qPCR to better understand the regulation of $\mathrm{NO}$ and $\mathrm{N}_{2} \mathrm{O}$ peak emissions from different environments.

The conditions for $\mathrm{NO}$ and $\mathrm{N}_{2} \mathrm{O}$ formation in pure cultures and by chemical reactions begin to be better understood.

\section{REFERENCES}

Ahlers, B., Konig, W., and Bock, E. (1990). Nitrite reductase activity in Nitrobacter vulgaris. FEMS Microbiol. Lett. 67, 121-126.

Ahn, J. H., Kim, S., Park, H., Rahm, B., Pagilla, K., and Chandran, K. (2010). $\mathrm{N}_{2} \mathrm{O}$ emissions from activated sludge processes, 2008-2009, results of a national monitoring survey in the United States. Environ. Sci. Technol. 44, 4505-4511.

Ahn, J. H., Kwan, T., and Chandran, K. (2011). Comparison of partial and full nitrification processes applied for treating high-strength nitrogen wastewaters: microbial ecology through nitrous oxide production. Environ. Sci. Technol. 45, 2734-2740.

Alluisetti, G. E., Almaraz, A. E., Amorebieta, V. T., Doctorovich, F., and Olabe, J. A. (2004). Metal-catalyzed anaerobic disproportionation of hydroxylamine. Role of diazene and nitroxyl intermediates in the formation of $\mathrm{N}_{2}$, $\mathrm{N}_{2} \mathrm{O}, \mathrm{NO}+$, and $\mathrm{NH}_{3}$. J. Am. Chem. Soc. 126, 13432-13442.

Andersen, K., Kjaer, T., and Revsbech, N. P. (2001). An oxygen insensitive microsensor for nitrous oxide. Sensor. Actuat. B Chem. 81, 42-48.

Anderson, J. H. (1964). The copper-catalysed oxidation of hydroxylamine. Analyst 89, 357-362.

Anjum, M. F., Stevanin, T. M., Read, R. C., and Moir, J. W. B. (2002). Nitric oxide metabolism in Neisseria meningitidis. J. Bacteriol. 184, 2987-2993.

Avrahami, S., and Bohannan, B. J. M. (2009). $\mathrm{N}_{2} \mathrm{O}$ emission rates in a California meadow soil are influenced by fertilizer level, soil moisture and the community structure of ammonia-oxidizing bacteria. Glob. Change Biol. 15, 643-655.

Baggs, E. M. (2008). A review of stable isotope techniques for $\mathrm{N}_{2} \mathrm{O}$ source partitioning in soils: recent progress, remaining challenges and future considerations. Rapid
Commun. Mass Spectrom. 22, 1664-1672.

Baggs, E. M. (2011). Soil microbial sources of nitrous oxide: recent advances in knowledge, emerging challenges and future direction. Curr. Opin. Environ. Sust. 3, 321-327.

Baggs, E. M., and Blum, H. (2004). $\mathrm{CH}_{4}$ oxidation and emissions of $\mathrm{CH}_{4}$ and $\mathrm{N}_{2} \mathrm{O}$ from Lolium perenne swards under elevated atmospheric $\mathrm{CO}_{2}$. Soil Biol. Biochem. 36, 713-723.

Bateman, E. J., and Baggs, E. M. (2005). Contributions of nitrification and denitrification to $\mathrm{N}_{2} \mathrm{O}$ emissions from soils at different water-filled pore space. Biol. Fertil. Soils 41, 379-388.

Bauer, S. (1995). Membrane introduction mass spectrometry; an old method that is gaining new interest through recent technological advances. Trends Anal. Chem. 14, 202-213.

Baulch, H. M., Schiff, S. L., Thuss, S. J., and Dillon, P. J. (2011). Isotopic character of nitrous oxide emitted from streams. Environ. Sci. Technol. 45, 4682-4688.

Baumann, B., Snozzi, M., Zehnder, A. J., and van der Meer, J. R. (1996). Dynamics of denitrification activity of Paracoccus denitrificans in continuous culture during aerobicanaerobic changes. J. Bacteriol. 178, 4367-4374.

Beaulieu, J. J., Tank, J. L., Hamilton, S. K., Wollheim, W. M., Hall, R. O., Mulholland, P. J., et al. (2011). Nitrous oxide emission from denitrification in stream and river networks. Proc. Natl. Acad. Sci. U.S.A. 108, 214-219.

Beaumont, H. J. E., Hommes, N. G., Sayavedra-Soto, L. A., Arp, D. J., Arciero, D. M., Hooper, A. B., et al. (2002). Nitrite reductase of Nitrosomonas europaea is not essential for production of gaseous nitrogen oxides and confers tolerance to nitrite. J. Bacteriol. 184, 2557-2560.

Beaumont, H. J. E., Lens, S. I., Reijnders, W. N. M., Westerhoff,

Furthermore, several recent technological advancements allow researcher to investigate the regulation of $\mathrm{NO}$ and $\mathrm{N}_{2} \mathrm{O}$ formation in complex environments at high spatial and temporal resolution. These advancements provide a cornerstone to understand and mitigate the release of $\mathrm{NO}$ and $\mathrm{N}_{2} \mathrm{O}$ from natural and engineered environments.

\section{ACKNOWLEDGMENTS}

We thank Joachim Mohn (Swiss Federal Laboratories for Materials Testing and Research, Empa) for helpful discussions during the preparation of the manuscript.

H. V., and van Spanning, R. J. M. (2004a). Expression of nitrite reductase in Nitrosomonas europaea involves NsrR, a novel nitritesensitive transcription repressor. Mol. Microbiol. 54, 148-158.

Beaumont, H. J. E., van Schooten, B., Lens, S. I., Westerhoff, H. V., and van Spanning, R. J. M. (2004b). Nitrosomonas europaea expresses a nitric oxide reductase during nitrification. J. Bacteriol. 186, 4417-4421.

Bedioui, F., and Villeneuve, N. (2003). Electrochemical nitric oxide sensors for biological samples - principle, selected examples and applications. Electroanalysis 15, 5-18.

Bergaust, L., Bakken, L. R. and Frostegård, A. (2011). Denitrification regulatory phenotype, a new term for the characterization of denitrifying bacteria. Biochem. Soc. Trans. 39, 207-212.

Bergaust, L., Mao, Y., Bakken, L. R., and Frostegård, A. (2010). Denitrification response patterns during the transition to anoxic respiration and posttranscriptional effects of suboptimal $\mathrm{pH}$ on nitrous oxide reductase in Paracoccus denitrificans. Appl. Environ. Microbiol. 76, 6387-6396.

Berks, B. C., Baratta, D., Richardson, J., and Ferguson, S. J. (1993). Purification and characterization of a nitrous oxide reductase from Thiosphaera pantotropha. Implications for the mechanism of aerobic nitrous oxide reduction. Eur. J. Biochem. 212, 467-476.

Bollmann, A., and Conrad, R. (1998). Influence of $\mathrm{O}_{2}$ availability on $\mathrm{NO}$ and $\mathrm{N}_{2} \mathrm{O}$ release by nitrification and denitrification in soils. Glob. Change Biol. 4, 387-396.

Bonner, F. T., Dzelzkalns, L. S., and Bonucci, J. A. (1978). Properties of nitroxyl as intermediate in the nitric oxide-hydroxylamine reaction and in trioxodinitrate decomposition. Inorg. Chem. 17, 2487-2494.

Bonner, F. T., and Hughes, M. N. (1988). The aqueous solution chemistry of nitrogen in low positive oxidation states. Comments Inorg. Chem. 7, 215-234.

Bonner, F. T., and Stedman, G. (1996). "The chemistry of nitric oxide and redox-related species," in Methods in Nitric Oxide Research, eds M. Feelisch and J. S. Stamler (New York, NY: John Wiley and Sons), 3-18.

Braker, G., and Conrad, R. (2011). Diversity, structure, and size of $\mathrm{N}_{2} \mathrm{O}$ producing microbial communities in soil - what matters for their functioning? Adv. Appl. Microbiol. 75, 33-69.

Braker, G., Dörsch, P., and Bakken, L. R. (2012). Genetic characterization of denitrifier communities with contrasting intrinsic functional traits. FEMS Microbiol. Ecol. 79, 542-554.

Braker, G., Fesefeldt, A., and Witzel, K.-P. (1998). Development of PCR primer systems for amplification of nitrite reductase genes (nirK and nirS) to detect denitrifying bacteria in environmental samples. Appl. Environ. Microbiol. 64, 3769-3775.

Braker, G., and Tiedje, J. M. (2003). Nitric oxide reductase (norB) genes from pure cultures and environmental samples. Appl. Environ. Microbiol. 69, 3476-3483.

Brenninkmeijer, C. A. M., and Röckmann, T. (1999). Mass spectrometry of the intramolecular nitrogen isotope distribution of environmental nitrous oxide using fragment-ion analysis. Rapid Commun. Mass Spectrom. 13, 2028-2033.

Bru, D., Ramette, A., Saby, N. P. A., Dequiedt, S., Ranjard, L., Jolivet, C., et al. (2011). Determinants of the distribution of nitrogen-cycling microbial communities at the landscape scale. ISME J. 5, 532-542.

Bru, D., Sarr, A., and Philippot, L. (2007). Relative abundances of proteobacterial membrane-bound and periplasmic nitrate reductases in selected environments. Appl. Environ. Microbiol. 73, 5971-5974.

Butler, J. H., and Gordon, L. I. (1986a). An improved gas chromatographic 
method for the measurement of hydroxylamine in marine and fresh waters. Mar. Chem. 19, 229-243.

Butler, J. H., and Gordon, L. I. (1986b). Rates of nitrous oxide production in the oxidation of hydroxylamine by iron (III). Inorg. Chem. 25, 4573-4577.

Cabail, M. Z., Kostera, J., and Pacheco, A. A. (2005). Laser photoinitiated nitrosylation of 3-electron reduced $\mathrm{Nm}$ europaea hydroxylamine oxidoreductase: kinetic and thermodynamic properties of the nitrosylated enzyme. Inorg. Chem. 44, 225-231.

Cabail, M. Z., and Pacheco, A. A. (2003). Selective one-electron reduction of Nitrosomonas europaea hydroxylamine oxidoreductase with nitric oxide. Inorg. Chem. 42, 270-272.

Cantera, J. J. L., and Stein, L. Y. (2007). Molecular diversity of nitrite reductase genes (nirK) in nitrifying bacteria. Environ. Microbiol. 9, 765-776.

Casciotti, K. L., Sigman, D. M., and Ward, B. B. (2003). Linking diversity and stable isotope fractionation in ammonia-oxidizing bacteria. Geomicrobiol. J. 20, 335-353.

Cavigelli, M. A., and Robertson, G. P. (2000). The functional significance of denitrifier community composition in a terrestrial ecosystem. Ecology 81, 1402-1414.

Chalk, P. M., and Smith, C. J. (1983). "Chemodenitrification," in Gaseous Loss of Nitrogen from Plant-Soil Systems, eds J. R. Freney and J. R. Simpson (Dordrecht, The Netherlands: Kluwer), 65-89.

Chandran, K., Stein, L. Y., Klotz, M. G., and van Loosdrecht, M. C. M. (2011). Nitrous oxide production by lithotrophic ammonia-oxidizing bacteria and implications for engineered nitrogen-removal systems. Biochem. Soc. Trans. 39, 1832-1837.

Charpentier, J., Farias, L., Yoshida, N., Boontanon, N., and Raimbault, P. (2007). Nitrous oxide distribution and its origin in the central and eastern South Pacific Subtropical Gyre. Biogeosciences 4, 729-741.

Corker, H., and Poole, R. K. (2003). Nitric oxide formation by Escherichia coli-dependence on nitrite reductase, the NO-sensing regulator Fnr, and flavohemoglobin Hmp. J. Biol. Chem. 278, 31584-31592.

Costa, C., Macedo, A., Moura, I., Moura, J. G. G., Le Gall, J., Berlier, Y., et al. (1990). Regulation of the hexaheme nitrite/nitric oxide reductase of Desulfovibrio desulfuricans, Wolinella succinogenes and Escherichia coli: a mass spectrometric study. FEBS Lett. 1, 67-70.
Crutzen, P. J. (1979). The role of NO and $\mathrm{NO}_{2}$ in the chemistry of the troposphere and stratosphere. Ann. Rev. Earth Planet. Sci. 7, 443-472.

Čuhel, J., Šimek, M., Laughlin, R. J., Bru, D., Chèneby, D., Watson, C. J., et al. (2010). Insights into the effect of soil $\mathrm{pH}$ on $\mathrm{N}_{2} \mathrm{O}$ and $\mathrm{N}_{2}$ emissions and denitrifier community size and activity. Appl. Environ. Microbiol. 76, 1870-1878.

Cutruzzolà, F. (1999). Bacterial nitric oxide synthesis. Biochim. Biophys. Acta 1411, 231-249.

Döring, C., and Gehlen, H. (1961). Über die Kinetic der Reaktion zwischen Hydroxylamin und Salpetriger Säure. Zeitschrift für anorganische und allgemeine Chemie 312, 32-44.

DuMond, J. F., and King, S. B. (2011). The chemistry of nitroxyl-releasing compounds. Antioxid. Redox Signal. 14, 1637-1648.

Elberling, B., Christiansen, H. H., and Hansen, B. U. (2010). High nitrous oxide production from thawing permafrost. Nat. Geosci. 3, 332-335.

Elkins, J. W., Wofsy, S. C., McElroy, M. B., Kolb, C. E., and Kaplan, W. A. (1978). Aquatic sources and sinks for nitrous oxide. Nature 275, 602-606.

Eschenbach, W., and Well, R. (2011). Online measurement of denitrification rates in aquifer samples by an approach coupling an automated sampling and calibration unit to a membrane inlet mass spectrometry system. Rapid Commun. Mass Spectrom. 25, 1993-2006.

Ettwig, K. F., Butler, M. K., Le Paslier, D., Pelletier, E., Mangenot, S., Kuypers, M. M. M., et al. (2010). Nitrite-driven anaerobic methane oxidation by oxygenic bacteria. Nature 464, 543-548.

Farias, L., Paulmier, A., and Gallegos, M. (2007). Nitrous oxide and Nnutrient cycling in the oxygen minimum zone off northern Chile. Deep Sea Res. 54, 164-180.

Fehling, C., and Friedrichs, G. (2011). Dimerization of $\mathrm{HNO}$ in aqueous solution: an interplay of solvation effects, fast acid-base equilibria, and intramolecular hydrogen bonding? J. Am. Chem. Soc. 133, 17912-17922.

Fernández, M. L., Estrin, D. A., and Bari, S. E. (2008). Theoretical insight into the hydroxylamine oxidoreductase mechanism. J. Inorg. Biochem. 102, 1523-1530.

Firestone, M. K., Firestone, R. B., and Tiedje, J. M. (1980). Nitrous oxide from soil denitrification: factors controlling its biological production. Science 208, 749-751.
Firestone, M. K., and Tiedje, J. M. (1979). Temporal change in nitrous oxide and dinitrogen from denitrification following onset of anaerobiosis. Appl. Environ. Microbiol. 38, 673-679.

Frame, C. H., and Casciotti, K. L. (2010). Biogeochemical controls and isotopic signatures of nitrous oxide production by a marine ammonia-oxidizing bacterium. Biogeosciences 7, 2695-2709.

Francis, C. A., Roberts, K. J., Beman, J. M., Santoro, A. E., and Oakley, B. B. (2005). Ubiquity and diversity of ammonia-oxidizing archaea in water columns and sediments of the ocean. Proc. Natl. Acad. Sci. U.S.A. 102, 14683-14688.

Freitag, A., Rudert, M., and Bock, E. (1987). Growth of nitrobacter by dissimilatoric nitrate reduction. FEMS Microbiol. Lett. 48, 105-109.

Friedemann, M. N., Robinson, S. W., and Gerhardt, G. A. (1996). oPhenylenediamine-modified carbon fiber electrodes for the detection of nitric oxide. Anal. Chem. 68, 2621-2628.

Frunzke, K., and Zumft, W. (1986). Inhibition of nitrous-oxide respiration by nitric oxide in the denitrifying bacterium Pseudomonas perfectomarina. Biochim. Biophys. Acta 852, 119-125.

Gao, H., Schreiber, F., Collins, G. Jensen, M. M., Svitlica, O., Kostka, J. E., et al. (2010). Aerobic denitrification in permeable Wadden Sea sediments. ISME J. 4, 417-426.

Garbeva, P., Baggs, E. M., and Prosser, J. I. (2007). Phylogeny of nitrite reductase (nirK) and nitric oxide reductase (norB) genes from Nitrosospira species isolated from soil. FEMS Microbiol. Lett. 266, 83-89.

Garcia-Lledo, A., Vilar-Sanz, A., Trias, R., Hallin, S., and Baneras, L. (2011). Genetic potential for $\mathrm{N}_{2} \mathrm{O}$ emissions from the sediment of a free water surface constructed wetland. Water Res. 45, 5621-5632.

Gardner, A. M., Helmick, R. A., and Gardner, P. R. (2002). Flavorubredoxin, an inducible catalyst for nitric oxide reduction and detoxification in Escherichia coli. J. Biol. Chem. 277, 8172-8177.

Gardner, P. R., Gardner, A. M., Martin, L. A., and Salzman, A. L. (1998). Nitric oxide dioxygenase: an enzymic function for flavohemoglobin. Proc. Natl. Acad. Sci. U.S.A. 95, 10378-10383.

Geets, J., de Cooman, M., Wittebolle, L., Heylen, K., Vanparys, B., De Vos, P., et al. (2007). Real-time PCR assay for the simultaneous quantification of nitrifying and denitrifying bacteria in activated sludge. Appl. Microbiol. Biotechnol. 75, 211-221.

Gentile, M. E., Lynn Nyman, J., and Criddle, C. S. (2007). Correlation of patterns of denitrification instability in replicated bioreactor communities with shifts in the relative abundance and the denitrification patterns of specific populations. ISME J. 1, 714-728.

Gieseke, A., and de Beer, D. (2004). "Use of microelectrodes to measure in situ microbial activities in biofilms, sediments, and microbial mats," in Molecular Microbial Ecology Manual, eds G. Kowalchuk, F. de Bruijn, I. Head, A. Akkermans, and J. van Elsas (Heidelberg: Springer), 1581-1612.

Gilberthorpe, N. J., and Poole, R. K (2008). Nitric oxide homeostasis in Salmonella typhimurium: roles of respiratory nitrate reductase and flavohemoglobin. J. Biol. Chem. 283, 11146-11154.

Gödde, M., and Conrad, R. (2000). Influence of soil properties on the turnover of nitric oxide and nitrous oxide by nitrification and denitrification at constant temperature and moisture. Biol. Fertil. Soils 32 120-128.

Gomes, C. M., Giuffrè, A., Forte, E., Vicente, J. B., Saraiva, L. M., Brunori, M., et al. (2002). A novel type of nitric-oxide reductase. Escherichia coli flavorubredoxin. J. Biol. Chem. 277, 25273-25276.

Granger, J., and Ward, B. B. (2012). Accumulation of nitrogen oxides in copper-limited cultures of denitrifying bacteria. Limnol. Oceanogr. 48, 313-318.

Hallin, S., Jones, C. M., Schloter, M., and Philippot, L. (2009). Relationship between N-cycling communities and ecosystem functioning in a 50-year-old fertilization experiment. ISME J. 3, 597-605.

Heisterkamp, I., Schramm, A., de Beer, D., and Stief, P. (2010). Nitrous oxide production associated with coastal marine invertebrates. Mar. Ecol. Prog. Ser. 415, 1-9.

Hendrich, M. P., Upadhyay, A. K., Riga, J., Arciero, D. M., and Hooper, A. B. (2002). Spectroscopic characterization of the NO adduct of hydroxylamine oxidoreductase. Biochemistry 41, 4603-4611.

Hendriks, J., Oubrie, A., Castresana, J., Urbani, A., Gemeinhardt, S., and Saraste, M. (2000). Nitric oxide reductases in bacteria. Biochim. Biophys. Acta 1459, 266-273.

Henry, S., Baudoin, E., Lopezgutierrez, J., Martinlaurent, F., Brauman, 
A., and Philippot, L. (2004). Quantification of denitrifying bacteria in soils by gene targeted real-time PCR. J. Microbiol. Methods 59, 327-335.

Henry, S., Bru, D., Stres, B., Hallet, S., and Philippot, L. (2006). Quantitative detection of the nosZ gene, encoding nitrous oxide reductase, and comparison of the abundances of 16S rRNA, narG, nirK, and nosZ genes in soils. Appl. Environ. Microbiol. 72, 5181-5189.

Hojberg, O., Revsbech, N. P., and Tiedje, J. M. (1994). Denitrification in soil aggregates analyzed with microsensors for nitrous oxide and oxygen. Soil Sci. Soc. Am. J. 58, 1691-1698.

Hooper, A. B. (1968). A nitritereducing enzyme from Nitrosomonas europaea: preliminary characterization with hydroxylamine as electron donor. Biochim. Biophys. Acta 162, 49-65.

Hooper, A. B., and Terry, K. R. (1979). Hydroxylamine oxidoreductase of Nitrosomonas. Production of nitric oxide from hydroxylamine. Biochim. Biophys. Acta 571, 12-20.

Horn, M. A., Schramm, A., and Drake, H. L. (2003). The earthworm gut: an ideal habitat for ingested $\mathrm{N}_{2} \mathrm{O}$ producing microorganisms. Appl. Environ. Microbiol. 69, 1662-1669.

Hu, H. Y., Goto, N., and Fujie, K. (2001). Effect of pH on the reduction of nitrite in water by metallic iron. Water Res. 35, 2789-2793.

Igarashi, N., Moriyama, H., Fujiwara, T., Fukumori, Y., and Tanaka, N. (1997). The $2.8 \AA$ structure of hydroxylamine oxidoreductase from a nitrifying chemoautotrophic bacterium, Nitrosomonas europaea. Nat. Struct. Biol. 4, 276-284.

IPCC. (2001). Climate Change 2001: The Scientific Basis. Cambridge, UK: Cambridge University Press.

Jenni, S., Mohn, J., Emmenegger, L., and Udert, K. M. (2012). Temperature dependence and interferences of $\mathrm{NO}$ and $\mathrm{N}_{2} \mathrm{O}$ microelectrodes used in wastewater treatment. Environ. Sci. Technol. 46, 2257-2266.

Jeroschewski, P., Steuckart, C., and Kühl, M. (1996). An amperometric microsensor for the determination of $\mathrm{H}_{2} \mathrm{~S}$ in aquatic environments. Anal. Chem. 68, 4351-4357.

Jinuntuya-Nortman, M., Sutka, R. L., Ostrom, P. H., Gandhi, H., and Ostrom, N. E. (2008). Isotopologue fractionation during microbial reduction of $\mathrm{N}_{2} \mathrm{O}$ within soil mesocosms as a function of water-filled pore space. Soil Biol. Biochem. 40, 2273-2280.
Jones, C. M., Stres, B., Rosenquist, M., and Hallin, S. (2008). Phylogenetic analysis of nitrite, nitric oxide, and nitrous oxide respiratory enzymes reveal a complex evolutionary history for denitrification. Mol. Biol. Evol. 25, 1955-1966.

Kampschreur, M. J., Kleerebezem, R., de Vet, W. W. J. M., and Van Loosdrecht, M. C. M. (2011). Reduced iron induced nitric oxide and nitrous oxide emission. Water Res. 45, 5945-5952.

Kampschreur, M. J., van der Star, W. R. L., Wielders, H. A., Mulder, J. W., Jetten, M. S. M., and van Loosdrecht, M. C. M. (2008a). Dynamics of nitric oxide and nitrous oxide emission during full-scale reject water treatment. Water Res. 42, 812-826.

Kampschreur, M. J., Tan, N. C. G., Kleerebezem, R., Picioreanu, C., Jetten, M. S. M., and van Loosdrecht, M. C. M. (2008b). Effect of dynamic process conditions on nitrogen oxides emission from a nitrifying culture. Environ. Sci. Technol. 42, 429-435.

Kampschreur, M. J., Temmink, H., Kleerebezem, R., Jetten, M. S. M., and van Loosdrecht, M. C. M. (2009). Nitrous oxide emission during wastewater treatment. Water Res. 43, 4093-4103.

Kartal, B., Maalcke, W. J., de Almeida, N. M., Cirpus, I., Gloerich, J., Geerts, W., et al. (2011). Molecular mechanism of anaerobic ammonium oxidation. Nature 479, 127-130.

Kartal, B., Tan, N. C. G., Van de Biezen, E., Kampschreur, M. J., Van Loosdrecht, M. C. M., and Jetten, M. S. M. (2010). Effect of nitric oxide on anammox bacteria. Appl. Environ. Microbiol. 76, 6304-6306.

Kester, R. A., de Boer, W., and Laanbroek, H. J. (1997). Production of $\mathrm{NO}$ and $\mathrm{N}_{2} \mathrm{O}$ by pure cultures of nitrifying and denitrifying bacteria during changes in aeration. Appl. Environ. Microbiol. 63, 3872-3877.

Kim, S. O., Orii, Y., Lloyd, D., Hughes, M. N., and Poole, R. K. (1999). Anoxic function for the Escherichia coli flavohaemoglobin (Hmp): reversible binding of nitric oxide and reduction to nitrous oxide. FEBS Lett. 445, 389-394.

Kitamura, Y., Uzawa, T., Oka, K., Komai, Y., Ogawa, H., Takizawa, N., et al. (2000). Microcoaxial electrode for in vivo nitric oxide measurement. Anal. Chem. 72, 2957-2962.

Kloos, K., Mergel, A., Sch, C., and Bothe, H. (2001). Denitrification within the genus Azospirillum and other associative bacteria. Funct. Plant Biol. 28, 991-998.

Koba, K., Osaka, K., Tobari, Y., Toyoda, S., Ohte, N., Katsuyama, M., et al. (2009). Biogeochemistry of nitrous oxide in groundwater in a forested ecosystem elucidated by nitrous oxide isotopomer measurements. Geochim. Cosmochim. Acta 73, 3115-3133.

Kool, D. M., Wrage, N., Oenema, O., Dolfing, J., and van Groenigen, J. W. (2007). Oxygen exchange between (de)nitrification intermediates and $\mathrm{H}_{2} \mathrm{O}$ and its implications for source determination of $\mathrm{NO}_{3}^{-}$and $\mathrm{N}_{2} \mathrm{O}$ : a review. Rapid Commun. Mass Spectrom. 21, 3569-3578.

Kool, D. M., Wrage, N., ZechmeisterBoltenstern, S., Pfeffer, M., Brus, D., Oenema, O., et al. (2010). Nitrifier denitrification can be a source of $\mathrm{N}_{2} \mathrm{O}$ from soil: a revised approach to the dual-isotope labelling method. Eur. J. Soil Sci. 61, 759-772.

Körner, H., and Zumft, W. G. (1989). Expression of denitrification enzymes in response to the dissolved oxygen level and respiratory substrate in continuous culture of Pseudomonas stutzeri. Appl. Environ. Microbiol. 55, 1670-1676.

Kostera, J., Youngblut, M. D. Slosarczyk, J. M., and Pacheco, A. A. (2008). Kinetic and product distribution analysis of $\mathrm{NO}^{*}$ reductase activity in Nitrosomonas europaea hydroxylamine oxidoreductase. J. Biol. Inorg. Chem. 13, 1073-1083.

Lammel, G., and Cape, J. N. (1996). Nitrous acid and nitrite in the atmosphere. Chem. Soc. Rev. 25, 361-369.

Law, Y., Ni, B.-J., Lant, P., and Yuan, Z. (2012). $\mathrm{N}_{2} \mathrm{O}$ production rate of an enriched ammonia-oxidising bacteria culture exponentially correlates to its ammonia oxidation rate. Water Res. 46, 3409-3419.

Lee, Y., Oh, B. K., and Meyerhoff, M. E. (2004). Improved planar amperometric nitric oxide sensor based on platinized platinum anode. 1 . Experimental results and theory when applied for monitoring NO release from diazeniumdiolatedoped polymeric films. Anal. Chem. 76, 536-544.

Liengaard, L., Nielsen, L. P., Revsbech, N. P., Elberling, B., Priemé, A., Prast, A. E., et al. (2011). Effects of flooding cycles in the Pantanal on the turnover of soil nitrogen pools and emission of $\mathrm{N}_{2} \mathrm{O}$. Biogeosci. Discuss. 8, 5991-6030.

Lipschultz, F., Zafiriou, O. C., Wofsy, S. C., McElroy, M. B., Valois, F. W., and Watson, S. W. (1981). Production of $\mathrm{NO}$ and $\mathrm{N}_{2} \mathrm{O}$ by soil nitrifying bacteria. Nature 294, 641-643.

Liu, B., Mørkved, P. T., Frostegård, Å., and Bakken, L. R. (2010). Denitrification gene pools, transcription and kinetics of $\mathrm{NO}, \mathrm{N}_{2} \mathrm{O}$ and $\mathrm{N}_{2}$ production as affected by soil pH. FEMS Microbiol. Ecol. 72, 407-417.

Lotito, A. M., Wunderlin, P., Joss, A., Kipf, M., and Siegrist, H. (2012). Nitrous oxide emissions from the oxidation tank of a pilot activated sludge plant. Water Res. 46, 3563-3573.

Lücker, S., Wagner, M., Maixner, F., Pelletier, E., Koch, H., and Vacherie, B. (2010). A Nitrospira metagenome illuminates the physiology and evolution of globally important nitrite-oxidizing bacteria. Proc. Natl. Acad. Sci. U.S.A. 107, 13479-13484.

Malinski, T., and Taha, Z. (1992). Nitric oxide release from a single cell measured in situ by a porphyrinic-based microsensor. Nature 358, 676-678.

Mariotti, A., Germon, J. C., Hubert, P., Kaiser, P., Letolle, R., Tardieux, A., et al. (1981). Experimental determination of nitrogen kinetic isotope fractionation: some principles; illustration for the denitrification and nitrification processes. Plant Soil 62, 413-430.

Markfoged, R., Nielsen, L. P., Nyord, T., Ottosen, L. D. M., and Revsbech, N. P. (2011). Transient $\mathrm{N}_{2} \mathrm{O}$ accumulation and emission caused by $\mathrm{O}_{2}$ depletion in soil after liquid manure injection. Eur. J. Soil Sci. 62, 541-550.

Meyer, R. L., Allen, D. E., and Schmidt, S. (2008). Nitrification and denitrification as sources of sediment nitrous oxide production: a microsensor approach. Mar. Chem. 110, 68-76.

Michotey, V., Mejean, V., and Bonin, P. (2000). Comparison of methods for quantification of cytochrome cd 1-denitrifying bacteria in environmental marine samples. Appl. Environ. Microbiol. 66, 1564-1571.

Miranda, K. M. (2005). The chemistry of nitroxyl (HNO) and implications in biology. Coord. Chem. Rev. 249, 433-455.

Moews, P. C. Jr., and Audrieth, L. F. (1959). The autoxidation of hydroxylamine. J. Inorg. Nucl. Chem. 11, 242-246.

Mohn, J., Guggenheim, C., Tuzson, B., Vollmer, M., Toyoda, S., Yoshida, N., et al. (2010). A liquid-free preconcentration unit for measurements of ambient $\mathrm{N}_{2} \mathrm{O}$ isotopomers by QCLAS. Atmos. Meas. Tech. 3, 609-618. 
Mohn, J., Tuzson, B., Manninen, A., Yoshida, N., Toyoda, S., Brand, W. A., et al. (2012). Site selective real-time measurements of ambient $\mathrm{N}_{2} \mathrm{O}$ isotopomers by laser spectroscopy. Atmos. Meas. Tech. Discuss. 5, 813-838.

Montzka, S. A., Dlugokencky, E. J., and Butler, J. H. (2011). Non$\mathrm{CO}_{2}$ greenhouse gases and climate change. Nature 476, 43-50.

Morales, S. E., Cosart, T., and Holben, W. E. (2010). Bacterial gene abundances as indicators of greenhouse gas emission in soils. ISME J. 4, 799-808.

Morales, S. E., and Holben, W. E. (2011). Linking bacterial identities and ecosystem processes: can "omic" analyses be more than the sum of their parts? FEMS Microbiol. Ecol. 75, 1-16.

Morley, N., Baggs, E. M., Dörsch, P., and Bakken, L. (2008). Production of $\mathrm{NO}, \mathrm{N}_{2} \mathrm{O}$ and $\mathrm{N}_{2}$ by extracted soil bacteria, regulation by $\mathrm{NO}_{2}(-)$ and $\mathrm{O}_{2}$ concentrations. FEMS Microbiol. Ecol. 65, 102-112.

Naqvi, S. W., Jayakumar, D. A., Narvekar, P. V., Naik, H., Sarma, V. V., et al. (2000). Increased marine production of $\mathrm{N}_{2} \mathrm{O}$ due to intensifying anoxia on the Indian continental shelf. Nature 408, 346-349.

Nicholls, J. C., Davies, C. A., and Trimmer, M. (2007). Highresolution profiles and nitrogen isotope tracing reveal a dominant source of nitrous oxide and multiple pathways of nitrogen gas formation in the central Arabian Sea. Limnol. Oceanogr. 52, 156-168.

Nielsen, M., Gieseke, A., de Beer, D., and Revsbech, N. (2009). Nitrate, nitrite, and nitrous oxide transformations in sediments along a salinity gradient in the Weser Estuary. Aquat. Microb. Ecol. 55, 39-52.

Okabe, S., Oshiki, M., Takahashi, Y., and Satoh, H. (2011). $\mathrm{N}_{2} \mathrm{O}$ emission from a partial nitrification-anammox process and identification of a key biological process of $\mathrm{N}_{2} \mathrm{O}$ emission from anammox granules. Water Res. 45, 6461-6470.

Otte, S., Grobben, N. G., Robertson, L. A., Jetten, M. S., and Kuenen, J. G. (1996). Nitrous oxide production by Alcaligenes faecalis under transient and dynamic aerobic and anaerobic conditions. Appl. Environ. Microbiol. 62, 2421-2426.

Palmer, K., Biasi, C., and Horn, M. A. (2012). Contrasting denitrifier communities relate to contrasting $\mathrm{N}_{2} \mathrm{O}$ emission patterns from acidic peat soils in arctic tundra. ISME J. 6 , 1058-1077.
Palmer, K., Drake, H. L., and Horn, M. A. (2010). Association of novel and highly diverse acid-tolerant denitrifiers with $\mathrm{N}_{2} \mathrm{O}$ fluxes of an acidic fen. Appl. Environ. Microbiol. 76 1125-1134.

Park, S., Croteau, P., Boering, K. A., Etheridge, D. M., Ferretti, D., Fraser, P. J., et al. (2012). Trends and seasonal cycles in the isotopic composition of nitrous oxide since 1940 . Nat. Geosci. 5, 261-265.

Park, S., Pérez, T., Boering, K. A., Trumbore, S. E., Gil, J., Marquina, S., et al. (2011). Can $\mathrm{N}_{2} \mathrm{O}$ stable isotopes and isotopomers be useful tools to characterize sources and microbial pathways of $\mathrm{N}_{2} \mathrm{O}$ production and consumption in tropical soils? Glob. Biogeochem. Cycles 25, GB1001.

Patureau, D., Zumstein, E., Delgenes, J. P., and Moletta, R. (2000). Aerobic denitrifiers isolated from diverse natural and managed ecosystems. Microb. Ecol. 39, 145-152.

Pellicer-Nàcher, C., Sun, S., Lackner, S., Terada, A., Schreiber, F., Zhou, Q., et al. (2010). Sequential aeration of membrane-aerated biofilm reactors for high-rate autotrophic nitrogen removal: experimental demonstration. Environ. Sci. Technol. 44, 7628-7634.

Perez, T., Garcia-Montiel, D., Trumbore, S., Tyler, S., de Camargo, P., et al. (2006). Nitrous oxide nitrification and denitrification ${ }^{15} \mathrm{~N}$ enrichment factors from amazon forest soils. Ecol. Appl. 16, 2153-2167.

Philippot, L., Andert, J., Jones, C. M., Bru, D., and Hallin, S. (2011). Importance of denitrifiers lacking the genes encoding the nitrous oxide reductase for $\mathrm{N}_{2} \mathrm{O}$ emissions from soil. Glob. Change Biol. 17, 1497-1504.

Philippot, L., Čuhel, J., Saby, N. P. A., Chèneby, D., Chroňáková, A., Bru, D., et al. (2009). Mapping field-scale spatial patterns of size and activity of the denitrifier community. Environ. Microbiol. 11, 1518-1526.

Poth, M. (1986). Dinitrogen production from nitrite by a Nitrosomonas isolate. Appl. Environ. Microbiol. 52, 957-959.

Poth, M., and Focht, D. D. (1985). ${ }^{15} \mathrm{~N}$ kinetic analysis of $\mathrm{N}_{2} \mathrm{O}$ production by Nitrosomonas: an examination of nitrifier denitrification. Appl. Environ. Microbiol. 49, 1134-1141.

Prosser, J. I., Jansson, J. K., and Liu, W.T. (2010). "Nucleic-acid-based characterization of community structure and function," in Environmental
Molecular Microbiology, eds W.-T. Liu and J. K. Jansson (Norfolk, UK: Caister Academic Press), 63-86.

Ramette, A. (2007). Multivariate analyses in microbial ecology. FEMS Microbiol. Ecol. 62, 142-160.

Ravishankara, A. R., Daniel, J. S., and Portmann, R. W. (2009). Nitrous oxide $\left(\mathrm{N}_{2} \mathrm{O}\right)$ : the dominant ozonedepleting substance emitted in the 21 st century. Science 326, 123-125.

Reed, H. E., and Martiny, J. B. H. (2007). Testing the functional significance of microbial composition in natural communities. FEMS Microbiol. Ecol. 62, 161-170.

Revsbech, N. P., Jørgensen, B. B., and Blackburn, T. H. (1980). Oxygen in the sea bottom measured with a microelectrode. Science 207, 1355-1356.

Revsbech, N. P., Nielsen, L. P., Christensen, P. B., and Sørensen, J. (1988). Combined oxygen and nitrous oxide microsensor for denitrification studies. Appl. Environ. Microbiol. 54, 2245-2249.

Richardson, D., Felgate, H., Watmough, N., Thomson, A., and Baggs, E. M. (2009). Mitigating release of the potent greenhouse gas $\mathrm{N}_{2} \mathrm{O}$ from the nitrogen cycle could enzymic regulation hold the key? Trends Biotechnol. 27, 388-397.

Rich, J. J., Heichen, R. S., Bottomley, P. J., Cromack, K., and Myrold, D. D. (2003). Community composition and functioning of denitrifying bacteria from adjacent meadow and forest soils. Appl. Environ. Microbiol. 69, 5974-5982.

Rich, J. J., and Myrold, D. D. (2004), Community composition and activities of denitrifying bacteria from adjacent agricultural soil, riparian soil, and creek sediment in Oregon, USA. Soil Biol. Biochem. 36, 1431-1441.

Ritchie, G. A., and Nicholas, D. J. (1972). Identification of the sources of nitrous oxide produced by oxidative and reductive processes in Nitrosomonas europaea. Biochem. J. 126, 1181-1191.

Rock, J. D., Thomson, M. J., Read, R. C., and Moir, J. W. B. (2007). Regulation of denitrification genes in Neisseria meningitidis by nitric oxide and the repressor NsrR. $J$. Bacteriol. 189, 1138-1144.

Rotthauwe, J. H., Witzel, K. P., and Liesack, W. (1997). The ammonia monooxygenase structural gene amoA as a functional marker: molecular fine-scale analysis of natural ammonia-oxidizing populations. Appl. Environ. Microbiol. 63, 4704-4712.
Santoro, A. E., Buchwald, C., Mcllvin, M. R., and Casciotti, K. L. (2011). Isotopic signature of $\mathrm{N}_{2} \mathrm{O}$ produced by marine ammonia-oxidizing archaea. Science 333, 7-10.

Schmidt, H. L., Werner, R. A., Yoshida, N., and Well, R. (2004a). Is the isotopic composition of nitrous oxide an indicator for its origin from nitrification or denitrification? A theoretical approach from referred data and microbiological and enzyme kinetic aspects. Rapid Commun. Mass Spectrom. 18, 2036-2040.

Schmidt, I., van Spanning, R. J. M., and Jetten, M. S. M. (2004b). Denitrification and ammonia oxidation by Nitrosomonas europaea wild-type, and NirK- and NorBdeficient mutants. Microbiology 150, 4107-4114.

Schmidt, I. (2009). Chemoorganoheterotrophic growth of Nitrosomonas europaea and Nitrosomonas eutropha. Curr. Microbiol. 59, 130-138.

Schreiber, F., Beutler, M., Enning, D., Lamprecht-Grandio, M., Zafra, O., González-Pastor, J. E., et al. (2011). The role of nitric-oxide-synthasederived nitric oxide in multicellular traits of Bacillus subtilis 3610, biofilm formation, swarming, and dispersal. BMC Microbiol. 11:111. doi: 10.1186/1471-2180-11-111

Schreiber, F., Loeffler, B., Polerecky, L., Kuypers, M. M. M., and de Beer, D. (2009). Mechanisms of transent nitric oxide and nitrous oxide production in a complex biofilm. ISME J. 3, 1301-1313.

Schreiber, F., Polerecky, L., and de Beer, D. (2008). Nitric oxide microsensor for high spatial resolution measurements in biofilms and sediments. Anal. Chem. 80, 1152-1158.

Schreiber, F., Stief, P., Gieseke, A., Heisterkamp, I. M., Verstraete, W., de Beer, D., et al. (2010). Denitrification in human dental plaque. BMC Biol. 8:24. doi: 10.1186/1741-7007-8-24

Schuurkes, J. A. A. R., and Mosello, R. (1988). The role of external ammonium inputs in freshwater acidification. Swiss J. Hydrol. 50, 71-87.

Schwartz, S. E., and White, W. H. (1981). Solubility equilibria of the nitrogen oxides and oxyacids in dilute aqueous solution. $A d v$. Environ. Sci. Eng. 4, 1-45.

Shafirovich, V., and Lymar, S. V. (2002). Nitroxyl and its anion in aqueous solutions: spin states, protic equilibria, and reactivities toward oxygen and nitric oxide. Proc. Natl. Acad. Sci. U.S.A. 99, 7340-7345. 
Shatalin, K., Gusarov, I., Avetissova, E., Shatalina, Y., McQuade, L. E., Lippard, S. J., et al. (2008). Bacillus anthracis-derived nitric oxide is essential for pathogen virulence and survival in macrophages. Proc. Natl. Acad. Sci. U.S.A. 105, 1009-1013.

Shaw, L. J., Nicol, G. W., Smith, Z., Fear, J., Prosser, J. I., and Baggs, E. M. (2006). Nitrosospira spp. can produce nitrous oxide via a nitrifier denitrification pathway. Environ. Microbiol. 8, 214-222.

Shibuki, K. (1990). An electrochemical microprobe for detecting nitric-oxide release in brain-tissue. Neurosci. Res. 9, 69-76.

Shin, J. H., Weinman, S. W., and Schoenfisch, M. H. (2005). Solgel derived amperometric nitric oxide microsensor. Anal. Chem. 77, 3494-3501.

Smith, C. J., and Osborn, A. M. (2008). Advantages and limitations of quantitative PCR (Q-PCR)-based approaches in microbial ecology. FEMS Microbiol. Ecol. 67, 6-20.

Snider, D. M., Schiff, S. L., and Spoelstra, J. (2009). ${ }^{15} \mathrm{~N} /{ }^{14} \mathrm{~N}$ and ${ }^{18} \mathrm{O} /{ }^{16} \mathrm{O}$ stable isotope ratios of nitrous oxide produced during denitrification in temperate forest soils. Geochim. Cosmochim. Acta 73, 877-888.

Sørensen, J., Tiedje, J. M., and Firestone, R. B. (1980). Inhibition by sulfide of nitric and nitrous oxide reduction by denitrifying Pseudomonas fluorescens. Appl. Environ. Microbiol. 39, 105-108.

Starkenburg, S. R., Arp, D. J., and Bottomley, P. J. (2008a). Expression of a putative nitrite reductase and the reversible inhibition of nitritedependent respiration by nitric oxide in Nitrobacter winogradskyi Nb-255. Environ. Microbiol. 10, 3036-3042.

Starkenburg, S. R., Chain, P. S. G., Sayavedra-Soto, L. A., Hauser, L., Land, M. L., Larimer, F. W., et al. (2006). Genome sequence of the chemolithoautotrophic nitriteoxidizing bacterium Nitrobacter winogradskyi Nb-255. Appl. Environ. Microbiol. 72, 2050-2063.

Starkenburg, S. R., Larimer, F. W., Stein, L. Y., Klotz, M. G., Chain, P. S. G., Luis, A., et al. (2008b). Complete genome sequence of nitrobacter hamburgensis X14 and comparative genomic analysis of species within the genus nitrobacter. Appl. Environ. Microbiol. 74, 2852-2863.

Stein, L. Y. (2011). Surveying $\mathrm{N}_{2} \mathrm{O}$-producing pathways in bacteria. Methods Enzymol. 486, 131-152.
Stein, L. Y., and Yung, Y. L. (2003). Production, isotopic composition, and a atmospheric fate of biologically produced nitrous oxide. Annu. Rev. Earth Planet. Sci. 31, 329-356.

Stief, P., Poulsen, M., Nielsen, L. P., Brix, H., and Schramm, A. (2009). Nitrous oxide emission by aquatic macrofauna. Proc. Natl. Acad. Sci. U.S.A. 106, 4296-4300.

Strous, M., Pelletier, E., Mangenot, S., Rattei, T., Lehner, A., Taylor, M. W., et al. (2006). Deciphering the evolution and metabolism of an anammox bacterium from a community genome. Nature 440, 790-794.

Sudhamsu, J., and Crane, B. R. (2009). Bacterial nitric oxide synthases: what are they good for? Trends Microbiol. 17, 212-218.

Sutka, R. L., Ostrom, N. E., Ostrom, P. H., Breznak, J. A., Gandhi, H., Pitt, A. J., et al. (2006). Distinguishing nitrous oxide production from nitrification and denitrification on the basis of isotopomer abundances. Appl. Environ. Microbiol. 72, 638-644.

Sutka, R. L., Ostrom, N. E., Ostrom, P. H., Gandhi, H., and Breznak, J. A. (2003). Nitrogen isotopomer site preference of $\mathrm{N}_{2} \mathrm{O}$ produced by Nitrosomonas europaea and Methylococcus capsulatus bath. Rapid Commun. Mass Spectrom. 17, 738-745.

Sutka, R. L., Ostrom, N. E., Ostrom, P. H., Gandhi, H., and Breznak, J. A. (2004). Nitrogen isotopomer site preference of $\mathrm{N}_{2} \mathrm{O}$ produced by Nitrosomonas europaea and Methylococcus capsulatus bath. Rapid Commun. Mass Spectrom. 18, 1411-1412.

Thomsen, J. K., Geest, T., and Cox, R. P. (1994). Mass spectrometric studies of the effect of $\mathrm{pH}$ on the accumulation of intermediates in denitrification by Paracoccus denitrificans. Appl. Environ. Microbiol. 60, 536-541.

Throbäck, I. N., Enwall, K., Jarvis, Å., and Hallin, S. (2004). Reassessing PCR primers targeting nirS, nirK and nosZ genes for community surveys of denitrifying bacteria with DGGE. FEMS Microbiol. Ecol. 49, 401-417.

Toyoda, S., Iwai, H., Koba, K., and Yoshida, N. (2009). Isotopomeric analysis of $\mathrm{N}_{2} \mathrm{O}$ dissolved in a river in the Tokyo metropolitan area. Rapid Commun. Mass Spectrom. 23, 809-821.

Toyoda, S., Mutobe, H., Yamagishi, H., Yoshida, N., and Tanji, Y. (2005). Fractionation of $\mathrm{N}_{2} \mathrm{O}$ isotopomers during production by denitrifier. Soil Biol. Biochem. 37, 1535-1545.

Toyoda, S., Suzuki, Y., Hattori, S., Yamada, K., Fujii, A., Yoshida, N., et al. (2011). Isotopomer analysis of production and consumption mechanisms of $\mathrm{N}_{2} \mathrm{O}$ and $\mathrm{CH}_{4}$ in an advanced wastewater treatment system. Environ. Sci. Technol. 45, 917-922.

Toyoda, S., and Yoshida, N. (1999). Determination of nitrogen isotopomers of nitrous oxide on a modified isotope ratio mass spectrometer. Anal. Chem. 71, 4711-4718.

Udert, K. M., Larsen, T. A., and Gujer, W. (2005). Chemical nitrite oxidation in acid solutions as a consequence of microbial ammonium oxidation. Environ. Sci. Technol. 39, 4066-4075.

Upadhyay, A. K., Hooper, A. B., and Hendrich, M. P. (2006). NO reductase activity of the tetraheme cytochrome C554 of Nitrosomonas europaea. J. Am. Chem. Soc. 128, 4330-4337.

van Cleemput, O. (1998). Subsoils: chemo- and biological denitrification, $\mathrm{N}_{2} \mathrm{O}$ and $\mathrm{N}_{2}$ emissions. Nutr. Cycl. Agroecosyst. 52, 187-194.

van Cleemput, O., and Samater, A. H. (1996). Nitrite in soils: accumulation and role in the formation of gaseous N compounds. Fertil. Res. 45, 81-89.

van Wonderen, J. H., Burlat, B., Richardson, D. J., Cheesman, M. R., and Butt, J. N. (2008). The nitric oxide reductase activity of cytochrome $\mathrm{c}$ nitrite reductase from Escherichia coli. J. Biol. Chem. 283, 9587-9594.

Vardi, A., Formiggini, F., Casotti, R., De Martino, A., Ribalet, F., Miralto, A., et al. (2006). A stress surveillance system based on calcium and nitric oxide in marine diatoms. PLoS Biol. 4:e60. doi: 10.1371/journal.pbio.0040060

Waechter, H., Mohn, J., Tuzson, B., Emmenegger, L., and Sigrist, M. W. (2008). Determination of $\mathrm{N}_{2} \mathrm{O}$ isotopomers with quantum cascade laser based absorption spectroscopy. Opt. Express 16, 9239-9244.

Wahlen, M., and Yoshinari, T. (1985). Oxygen isotope ratios in $\mathrm{N}_{2} \mathrm{O}$ from different environments. Nature 313 , 780-782.

Wallenstein, M. D., Myrold, D. D., Firestone, M., and Voytek, M. (2006). Environmental controls on denitrifying communities and denitrification rates: insights from molecular methods. Ecol. Appl. 16, 2143-2152.
Ward, B. B., and Zafiriou, O. C. (1988). Nitrification and nitric-oxide in the oxygen minimum of the eastern tropical North Pacific. Deep Sea Res. 35, 1127-1142.

Well, R., Kurganova, I. Lopesdegerenyu, V., and Flessa, H. (2006). Isotopomer signatures of soil-emitted $\mathrm{N}_{2} \mathrm{O}$ under different moisture conditions-a microcosm study with arable loess soil. Soil Biol. Biochem. 38, 2923-2933.

Wells, G. F., Park, H.-D., Yeung, C.-H., Eggleston, B., Francis, C. A., and Criddle, C. S. (2009). Ammonia-oxidizing communities in a highly aerated full-scale activated sludge bioreactor: betaproteobacterial dynamics and low relative abundance of Crenarchaea. Environ. Microbiol. 11, 2310-2328.

Westley, M. B., Popp, B. N., and Rust, T. M. (2007). The calibration of the intramolecular nitrogen isotope distribution in nitrous oxide measured by isotope ratio mass spectrometry. Rapid Commun. Mass Spectrom. 21, 391-405.

Wrage, N., Van Groenigen, J. W., Oenema, O., and Baggs, E. M. (2005). A novel dual-isotope labelling method for distinguishing between soil sources of $\mathrm{N}_{2} \mathrm{O}$. Rapid Commun. Mass Spectrom. 19, 3298-3306.

Wrage, N., Velthof, G. L., Beusichem, M. L. V., and Oenema, O. (2001) Role of nitrifier denitrification in the production of nitrous oxide. Soil Biol. Biochem. 33, 1723-1732.

Wunderlin, P., Mohn, J., Joss, A., Emmenegger, L., and Siegrist, $\mathrm{H}$. (2012). Mechanisms of $\mathrm{N}_{2} \mathrm{O}$ production in biological wastewater treatment under nitrifying and denitrifying conditions. Water Res. 46, 1027-1037.

Yamagishi, H., Westley, M. B., Popp, B. N., Toyoda, S., Yoshida, N., Watanabe, S., et al. (2007). Role of nitrification and denitrification on the nitrous oxide cycle in the eastern tropical North Pacific and Gulf of California. J. Geophys. Res. Biogeosci. 112, G02015.

Yoshida, N. (1988). ${ }^{15} \mathrm{~N}$-depleted $\mathrm{N}_{2} \mathrm{O}$ as a product of nitrification. Nature 335, 528-529.

Yoshida, N., Morimoto, H., Hirano, M., Koike, I., Matsuo, S., Wada, E., et al. (1989). Nitrification rates and N-15 abundances of $\mathrm{N}_{2} \mathrm{O}$ and $\mathrm{NO}_{3}^{-}$in the Western North Pacific. Nature 342, 895-897.

Yoshinari, T., and Wahlen, M. (1985). Oxygen isotope ratios in $\mathrm{N}_{2} \mathrm{O}$ 
from nitrification at a wastewater treatment facility. Nature 317, 349-350.

Yu, R., Kampschreur, M. J., van Loosdrecht, M. C. M., and Chandran, K. (2010). Mechanisms and specific directionality of autotrophic nitrous oxide and nitric oxide generation during transient anoxia. Environ. Sci. Technol. 44, 1313-1319.

Zafiriou, O. C., Mcfarland, M., and Bromund, R. H. (1980). Nitricoxide in seawater. Science 207, 637-639.

Zafiriou, O. C., and True, M. B. (1979). Nitrite photolysis in seawater by sunlight. Mar. Chem. 8, 9-32.

Zart, D., Schmidt, I., and Bock, E. (2000). Significance of gaseous NO for ammonia oxidation by
Nitrosomonas eutropha. Antonie van Leeuwenhoek 77, 49-55.

Zhou, Y., Pijuan, M., Zeng, R. J., and Yuan, Z. (2008). Free nitrous acid inhibition on nitrous oxide reduction by a denitrifying-enhanced biological phosphorus removal sludge. Environ. Sci. Technol. 42, 8260-8265.

Zumft, W. G. (1997). Cell biology and molecular basis of denitrification. Microbiol. Mol. Biol. Rev. 61, 533-616.

Zumft, W. G. (2005). Nitric oxide reductases of prokaryotes with emphasis on the respiratory, hemecopper oxidase type. J. Inorg. Biochem. 99, 194-215.

Zumft, W., and Kroneck, P. (2007). Respiratory transformation of nitrous oxide $\mathrm{N}_{2} \mathrm{O}$ to dinitrogen by
Bacteria and Archaea. Adv. Microb. Physiol. 52, 107.

Conflict of Interest Statement: Frank Schreiber has a license agreement with Unisense A/S for the constrution and distribution of an NO microelectrode. The other authors declare that the research was conducted in the absence of any commercial or financial relationships that could be construed as a potential conflict of interest.

Received: 30 April 2012; paper pending published: 11 June 2012; accepted: 28 September 2012; published online: 23 October 2012

Citation: Schreiber F, Wunderlin $P$ Udert KM and Wells GF (2012) Nitric oxide and nitrous oxide turnover in natural and engineered microbial communities: biological pathways, chemical reactions, and novel technologies. Front. Microbio. 3:372. doi: 10.3389/ fmicb.2012.00372

This article was submitted to Frontiers in Evolutionary and Genomic Microbiology, a specialty of Frontiers in Microbiology.

Copyright (C) 2012 Schreiber, Wunderlin, Udert and Wells. This is an open-access article distributed under the terms of the Creative Commons Attribution License, which permits use, distribution and reproduction in other forums, provided the original authors and source are credited and subject to any copyright notices concerning any third-party graphics etc. 